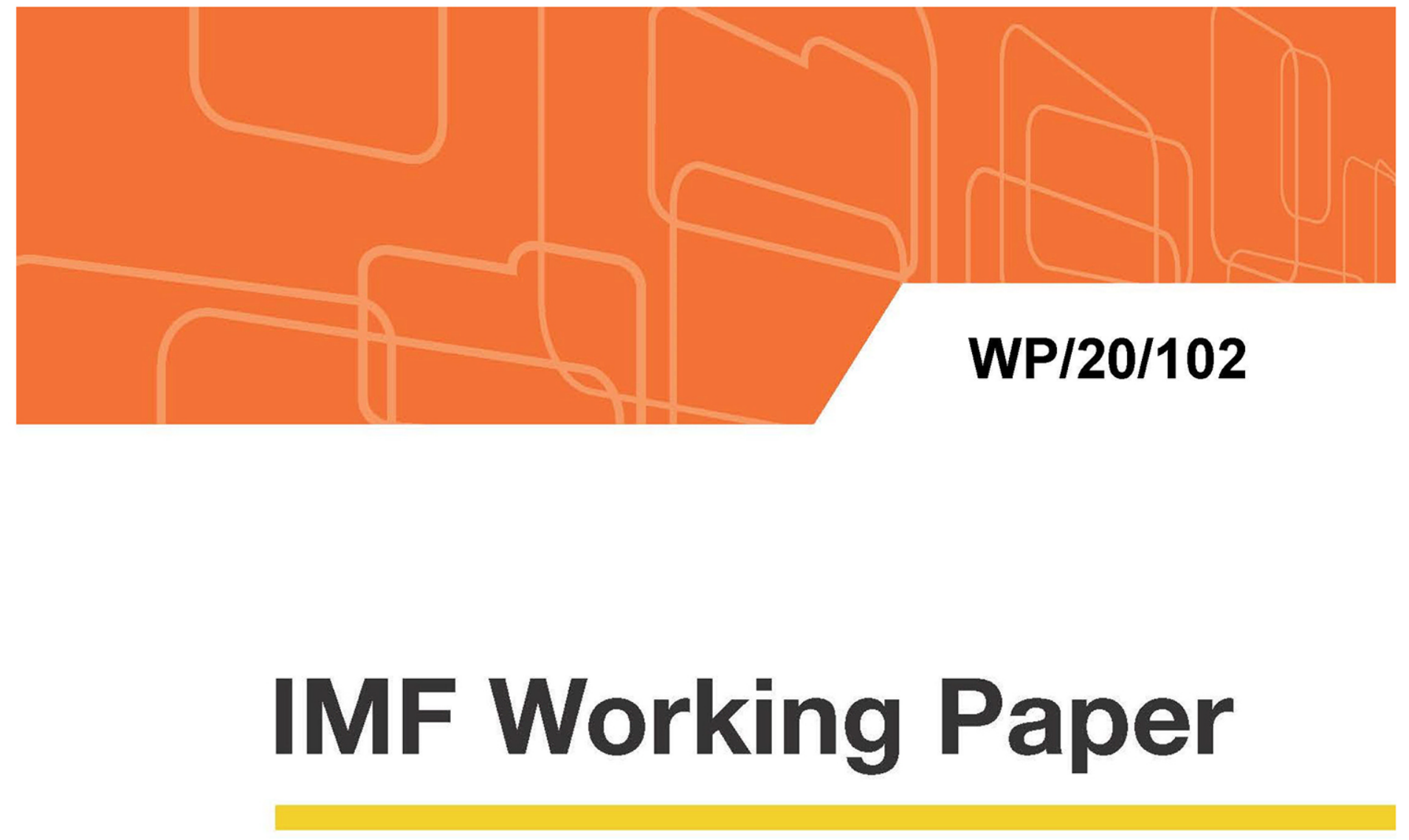

\title{
Debt, Investment, and Growth in Developing Countries with Segmented Labor Markets
}

By Edward F. Buffie, Luis-Felipe Zanna, Christopher Adam, Lacina Balma, Dawit Tessema, and Kangni Kpodar 


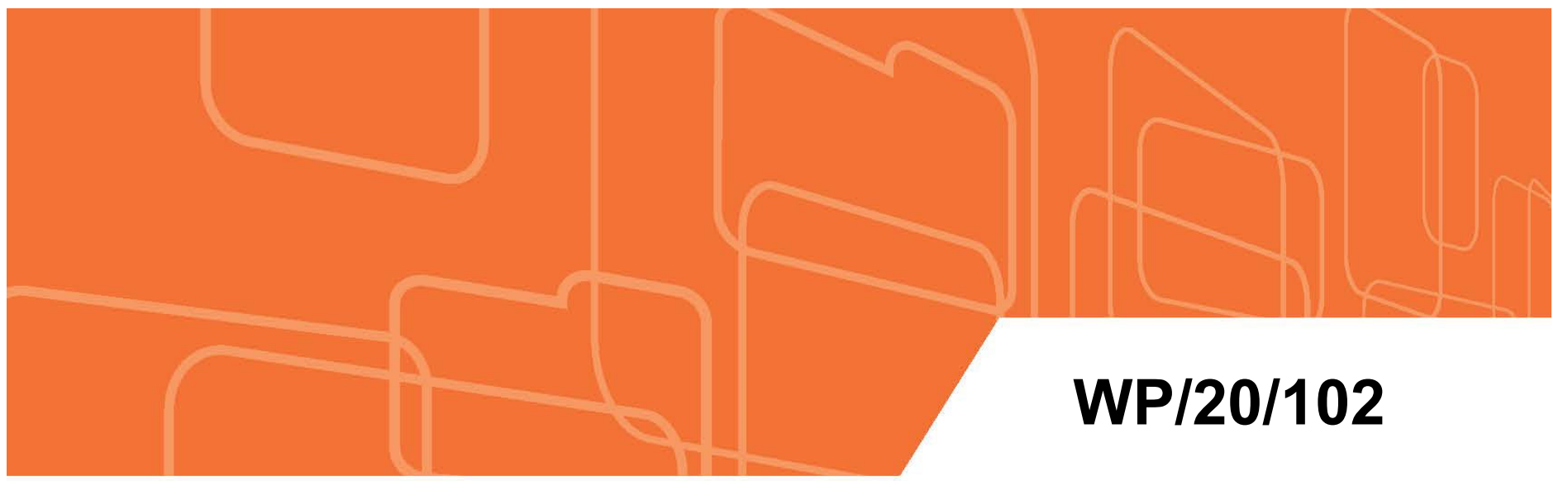

\section{IMF Working Paper}

\section{Debt, Investment, and Growth in Developing Countries with Segmented Labor Markets}

By Edward F. Buffie, Luis-Felipe Zanna, Christopher Adam, Lacina Balma, Dawit Tessema, and Kangni Kpodar 


\title{
IMF Working Paper
}

\author{
Institute for Capacity Development, Research Department, and Strategy, Policy, and Review \\ Department
}

\section{Debt, Investment, and Growth in Developing Countries with Segmented Labor Markets ${ }^{\dagger}$ \\ Prepared by Edward F. Buffie, Luis-Felipe Zanna, Christopher Adam, Lacina Balma, Dawit Tessema, and Kangni Kpodar}

\author{
Authorized for distribution by Valerie Cerra, Chris Papageorgiou, and Johannes Wiegand
}

June 2020

\begin{abstract}
Disclaimer: This document was prepared before COVID-19 became a global pandemic and resulted in unprecedented economic strains. It, therefore, does not reflect the implications of these developments and related policy priorities. We direct you to the IMF Covid-19 page that includes staff recommendations with regard to the COVID-19 global outbreak.
\end{abstract}

\begin{abstract}
We introduce a new suite of macroeconomic models that extend and complement the Debt, Investment, and Growth (DIG) model widely used at the IMF since 2012. The new DIG-Labor models feature segmented labor markets, efficiency wages and open unemployment, and an informal non-agricultural sector. These features allow for a deeper examination of macroeconomic and fiscal policy programs and their impact on labor market outcomes, inequality, and poverty. The paper illustrates the model's properties by analyzing the growth, debt, and distributional consequences of big-push public investment programs with different mixes of investment in human capital and infrastructure. We show that investment in human capital is much more effective than investment in infrastructure in promoting long-run economic development when investments earn their average estimated returns. The decision about how much to invest in human capital versus infrastructure involves, however, an acute intertemporal trade-off. Because investment in education affects labor productivity with a long lag, it takes $15+$ years before net national income, the private capital stock, real wages for the poor, and formal sector employment surpass their counterparts in a program that invests mainly in infrastructure. The ranking of alternative investment programs depends on the policymakers' social discount rate and on the weight of distributional objectives in the social welfare function.
\end{abstract}

JEL Classification Numbers: E62, F34, H54, H63, I25, I31, O43.

Keywords: Public Investment, Growth, Debt, Fiscal Policy, Human Capital, Labor Markets, Welfare.

Authors' E-Mail Addresses: ebuffie@indiana.edu; fzanna@imf.org; christopher.adam@qeh.ox.ac.uk;

1.balma@afdb.org; dtessema@imf.org; kkpodar@imf.org

\footnotetext{
$\dagger$ We thank Andy Berg, Chris Papageorgiou, Mark Flanagan, S M Ali Abbas, Giovanni Melina, Tom Best, Mariano Moszoro, and Samuele Rosa for useful comments. All errors remain ours. This joint AfDB-IMF research has been done in collaboration with the Macroeconomic Policy, Forecasting and Research Department of the African Development Bank (AfDB), and was generously supported by the AfDB under the KOAFEC Trust Fund, and the IMF under the DFID-IMF Macroeconomic Research in Low-Income Countries program. The views expressed in this paper are those of the authors and do not necessarily represent the views or policy of the IMF, DFID, or the AfDB. Working Papers describe research in progress by the authors and are published to elicit comments and to further debate.
} 
I. Introduction

II. Efficiency Wages, Productivity Gaps, and Segmentation: A Short, Idiosyncratic Survey of the Literature.

III. The DIG-Labor 1 Model ...................................................................................... 21

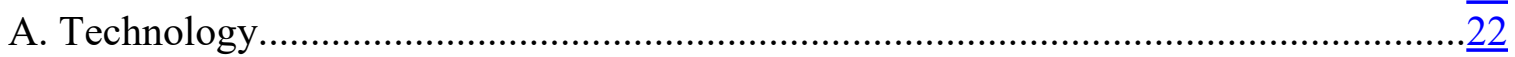

A.1. Production Functions ..................................................................... $\frac{22}{22}$

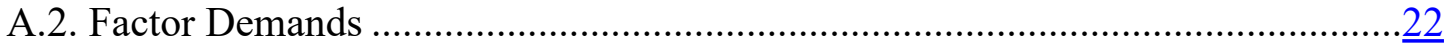

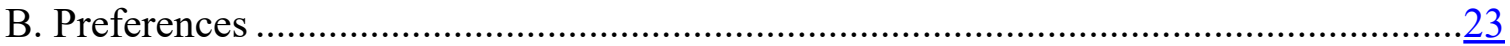

B.1. Household Optimization Problems …..................................................... $\frac{23}{26}$

C. Labor Market Features ................................................................................ $\frac{26}{26}$

C.1. The Effort Function ........................................................................... $\frac{26}{26}$

C.2. Efficiency Wages, Unemployment, and Underemployment.............................27

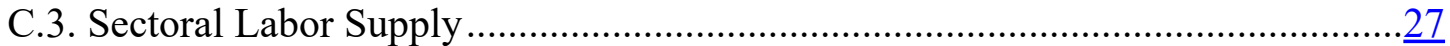

D. The Public Sector .......................................................................................

D.1. Public Investment in Infrastructure......................................................... $\frac{28}{29}$

D.2. Public Investment in Human Capital ............................................................

D.3. Fiscal Adjustment and the Public Sector Budget Constraint .............................29

E. Market-Clearing Conditions and External Debt Accumulation ..................................

IV. Calibration of the Model and Solution Technique................................................... $\frac{32}{32}$

A. Linking Some Parameters to Elasticities and Rates of Return.................................. $\frac{32}{34}$

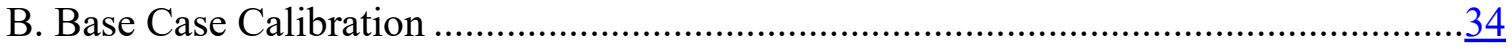

V. The Long-Run Trade-offs of Different Types of Public Investment.............................. $\underline{42}$

A. Increasing Investments One at a Time ...........................................................

B. The High Cost of Underfunding Maintenance .......................................................44

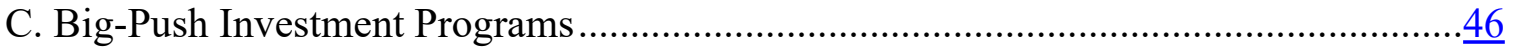

D. Pure vs. Mixed Investment Programs ................................................................. $\frac{46}{47}$

E. Ranking Some of the Contenders ..................................................................

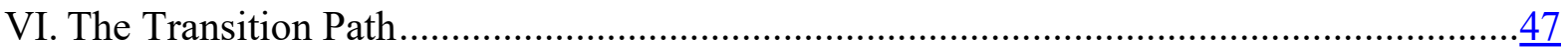

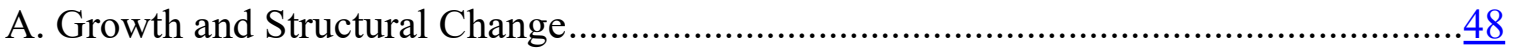

B. Fiscal Adjustment and Debt Dynamics ............................................................... $\frac{49}{40}$

C. Blended Public Investment Programs ................................................................. $\frac{\overline{50}}{\underline{50}}$

D. Intertemporal Trade-offs: Summary ............................................................

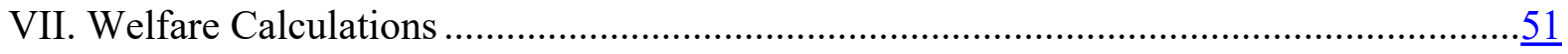

VIII. Where to From Here?................................................................................ 53

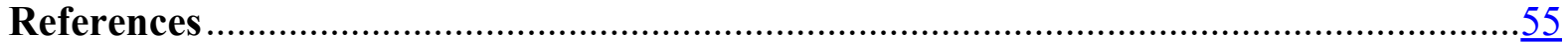




\section{Tables}

Table 1. The DIG-Labor Suite of Models: Alternative Specifications ...................................67

Table 2. Unemployment Rates in Less-Developed Countries .............................................68

Table 3. Calibration of the Model...............................................................................69

Table 4. Long-Run Effects of Increasing One Component of Public Investment ..................

Table 5. The High Cost of Neglecting Maintenance …................................................ $\frac{73}{74}$

Table 6. Long-Run Effects of Big-Push Programs That Increase Public Investment ............. 74

Table 7. Comparison of Welfare Gains in the Base Case $R_{u}=R_{b}=0.30(\varepsilon 3=5) \ldots \ldots \ldots \ldots \ldots . .16$

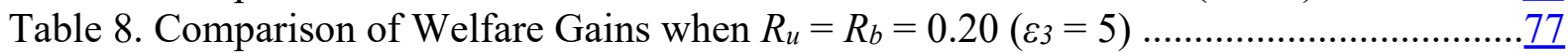

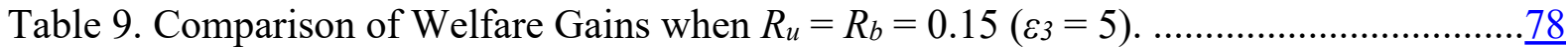

\section{Figures}

Figure 1. Correcting Sub-Optimal Maintenance Is a Free Lunch.......................................

Figure 2. Relationship Between Marginal General Equilibrium Returns and the Impact of the Investment Mix on Long-Run Output ...................................................... 80

Figure 3. Transition Paths for All-Infrastructure and All-Human Capital (Education) Investment Programs ................................................................................ $\frac{81}{82}$

Figure 4. Transition Paths for All-Infrastructure and Mixed Investment Programs................ $\underline{82}$

\section{Appendices}

A. Formal Sector Wage Premium and the Earnings Gap Between the Informal Sector and Agriculture

B. Wage Curves and Unemployment ..................................................................... 


\section{Introduction}

Big-push public investment programs financed by external debt remain the policy of choice for increasing growth and combatting poverty in developing countries (African Development Bank, 2018). These programs are envisaged to close serious infrastructure gaps, which are pervasive in these countries, as well as help achieve several sustainable development goals, including those related to health and education. Moreover, as climate change continues unabated, developing countries will need to invest in mitigation and adaptation technologies to respond to natural disasters.

How can policy makers decide whether to implement ambitious public investment programs? And how can they assess the macroeconomic effects of such programs, including on growth and debt? These are not simple questions. After all, these decisions and effects may depend on several factors, such as the needs in specific sectors, the prospects for sustainable financing (debt-financed versus budget neutral), and the efficiency and return of public investment. But even if policy makers are aware of these factors, and their role, how can they quantify the macroeconomic effects of public investment scale-ups?

To help answer these questions, the Debt, Investment, and Growth (DIG) model and the important extension for natural resource rich countries, the Debt, Investment, Growth and NAtural Resources (DIGNAR) model, were developed at the International Monetary Fund (IMF) — see Buffie et al. (2012), Melina et al. (2016), and Zanna et al. (2019). These models have gained a wide measure of acceptance in the policy world. Over the past eight years, the DIG and DIGNAR models have complemented the IMF and World Bank debt sustainability framework (DSF) analysis with over 65 country applications (Gurara et al., 2019). They have provided useful insights in the context of IMF programs and surveillance work, based on qualitative and quantitative analysis of the macroeconomic effects of public investment surges.

The DIG and DIGNAR models have their share of shortcomings, however. Most notably, the assumption of perfect wage flexibility and integrated labor markets is restrictive and increasingly unappealing. Open unemployment and underemployment are enduring, troublesome facts of life in many Low-Income Countries (LICs). The models shed light on how public investment programs affect aggregate labor demand in such countries, but they cannot speak directly to policy makers desire to reduce inequality and create more good jobs. The omission of rich and more realistic labor markets in these models is not surprising. To a great extent, the analysis of labor markets in developing countries

has not been central to the progress of development economics in the last two decades (Teal, 2011). But the need to incorporate richer labor markets in models that can inform policy decisions seems imperative, as argued by Fields (2011a):

"I briefly highlight four priority areas for future research.... The second is the need for

CInternational Monetary Fund. Not for Redistribution 
empirically grounded theoretical labor market models that can be used in the formulation of policy. There is some value in developing single-sector models and representative agent models, but it would be more helpful to have multi-sector models in which labor markets are segmented, incorporating the key features of labor markets in the country being analyzed."

In this paper, we present three new models: DIG-Labor 1, DIG-Labor 2, and DIG-Labor 3. Segmented labor markets are front and center in each model. Firms in the formal sector pay efficiency wages (EWs), while flexible wages prevail in agriculture. The third sector, the non-agricultural informal sector, is populated by wage employees in DIG-Labor 2 and by own-account workers in DIG-Labor 1 and DIG-Labor 3. In DIG-Labor 2, informal firms pay an EW below the wage in the formal sector. DIG-Labor 1 and 3 assume that labor earns the same return in the informal sector as in agriculture. The preferred model depends, of course, on the country under examination. DIG-Labor 1 is appropriate for most LICs, DIG-Labor 2 for most Middle-Income Countries (MICs) and Emerging Market Economies (EMEs), and DIG-Labor 3 for countries that suffer only from underemployment.

DIG-Labor 1-3 differ in the type and severity of the distortions that impair efficiency in the labor market (Table 1). There is open unemployment in DIG-Labor 1 and 2, but not in DIG-Labor 3. Furthermore, while involuntary unemployment pervades the entire non-agricultural sector in DIGLabor 2, in DIG-Labor 1 it is confined to the formal sector. Underemployment is a problem in all three models: for any given unemployment rate (zero in DIG-Labor 3), aggregate labor productivity increases when labor moves from the informal to the formal sector or from agriculture to either nonagricultural sector. In DIG-Labor 1 and 3, labor in smallholder agriculture receives its marginal value product plus a share of (implicit) land rents. Importantly, however, property rights are insecure or non-existent; consequently, though labor mobility enforces equal pay in agriculture and the informal sector, the marginal value product of labor is lower in agriculture. ${ }^{1}$ The same distortion may operate in DIG-Labor 2. But even when it does not, the EWs paid in the informal sector exceeds the marginal value product of labor in agriculture.

The DIG-Labor models contain a number of other new features besides segmented labor markets and a third sector. They incorporate skilled labor and public investment in human capital; maintenance investment as well as new investment in infrastructure; and sector-specific taxes on wages, profits, and consumption. These new features allow policy makers to specify the program for public investment and supporting fiscal adjustment in greater detail and to evaluate more accurately its impact on inequality,

\footnotetext{
${ }^{1} 80$ - 95 percent of land is untitled in most of Sub-Saharan Africa (Doss et al., 2015; Chen, 2017). Ejidos in Mexico and public land in China and Vietnam are other examples of communal land tenure systems where the "use it or lose it" principle applies. Chen (2017) and Gottlieb and Grobovsek (2019) analyze how such systems distort the allocation of labor, calibrating their models to Malawi and Ethiopia, respectively. Both find large gains from removal of communal land tenure. See also Wichern et al. (1999) and Thurlow and Wobst (2004) for discussions of how the lack of property rights for land inhibits rural labor mobility. Otsuka and Place (2001) and Otsuka (2007) emphasize this and other efficiency losses in Africa caused by the lack of individualized property rights to land.
} 
growth, unemployment, and underemployment. DIG-Labor 1-3, like DIG, are supported by Dynare + MATLAB programs that display the model solutions in graphs and tables. The programs are fully annotated and very user friendly.

The rest of the paper is organized into five sections. Before getting knee-deep in the equations, we take some space in Section II to survey the empirical evidence bearing on the size of the formal sector wage premium, the relevance of EWs, and the magnitude of unemployment, underemployment, and sectoral gaps in labor productivity. A consistent, if variegated, picture emerges from diverse strands of the literature. Labor markets are highly segmented in most developing countries, but the textbook model of competitive, flex-wage labor markets applies in some cases and different types of segmentation predominate at different points on the development spectrum. The cliché that one size does not fit all is correct: development macroeconomics needs to supply policy makers with choice from a small suite of models.

Sections III and IV develop and calibrate the DIG-Labor 1 model. Following this, we conduct policy experiments in Sections V-VII. The experiments are fewer in number but wider in scope than in Buffie et al. (2012) and Zanna et al. (2019). We delineate how the structure of the labor market and the split between maintenance investment, new infrastructure investment, and human capital investment in the big push program condition not only the prospects for debt dynamics and growth but also the impact on inequality, poverty, the supply of good jobs, and social welfare. The optimal investment program depends on how policy makers evaluate several difficult trade-offs and on their educated guesses for investment returns. Elaborating:

- Investment in human capital is much more effective than investment in infrastructure in promoting long-run economic development when investments earn their average estimated returns. Investing one percent of GDP in basic education increases aggregate consumption 10.2 percent and real income of the poor 10.3 percent across steady states. The corresponding numbers are 9.3 percent and 18.1 percent for investment in upper-level education (secondary + tertiary) and 4.3 percent and 5.4 percent for investment in infrastructure. The large disparity in economy-wide returns and gains for the poor reflect in equal parts higher partial equilibrium capital rentals and stronger pro-growth general equilibrium effects - more crowding-in of private capital and bigger reductions in unemployment and underemployment - for investment in human capital. ${ }^{2}$

- The decision about how much to invest in human capital versus infrastructure involves an acute intertemporal trade-off. Investment in education affects labor productivity with a 6- to 8-year lag. Consequently, it takes $15+$ years before net national income, the private capital stock, real

\footnotetext{
${ }^{2}$ The internal rates of return for basic and upper-level education in the base case map into partial equilibrium capital rentals ten percentage points above the rental for infrastructure.
}

CInternational Monetary Fund. Not for Redistribution 
wages for the poor, formal sector employment, etc., surpass their counterparts in a program that invests mainly in infrastructure.

- Big-push investment programs that emphasize human capital require more supporting fiscal adjustment. The delayed impact on growth delays the arrival of endogenous revenue gains in programs that invest heavily in human capital. Increasing the share of human capital in the investment program therefore entails more fiscal adjustment to avoid explosive debt dynamics and/or tolerance of a higher debt trajectory for several decades.

- Investing in basic education increases growth more but reduces poverty less than investment in upper-level education. Investment in basic education directly increases the productivity of lowskill labor. It is not, however, the public investment best suited to combatting poverty. That honor belongs to investment in upper-level education. Investment in secondary and tertiary education converts some workers who would otherwise be unskilled and poor into high-skill, well-paid workers. Moreover, workers who remain low-skill benefit indirectly. They decrease in number while the increase in the supply of high-skill labor raises their productivity. Thus, the demand curve for low-skill labor shifts to the right as the supply curve shifts to the left. The resulting increase in real wages for workers who remain low-skill combined with the jump in earnings for the newly skilled produces gains for the ex ante poor far above the gains generated by investment in infrastructure and basic education.

- The share of human capital in the optimal investment program is on the order of 50-100 percent in the base case. ${ }^{3}$ The long-run general equilibrium returns on investment in basic and upper-level education greatly exceed the long-run return on investment in infrastructure in the base case (see the first bullet). This pushes the share of human capital in the optimal investment program toward 100 percent. On the other hand, diminishing returns, strong gross complementarity of human capital and infrastructure, and the faster payoff to infrastructure all pull in the opposite direction, toward some type of mixed investment program. The optimal investment share for human capital depends on (i) policy makers' willingness, as measured by the social discount rate, to trade smaller development gains in the short/medium run for larger gains in the long run and (ii) the weight of distributional objectives in the social welfare function. In the base case, the optimal investment share is 50 - 75 percent as long as the social discount rate is 0.93 - 0.96 - i.e., no more than three percentage points above the private discount rate $(0.93)$ and the weight on the distributional objective is not too extreme. At social discount rates above 0.96 , the share for infrastructure drops to zero.

\footnotetext{
${ }^{3}$ We are using the term "optimal" very loosely here. The welfare results presented in Section VII demarcate the zone containing the optimal share for infrastructure investment, conditional on our educated guess that allocating one-third of human capital investments to upper-level education is roughly optimal.
} 
- Human capital maintains a sizeable share in the optimal investment program even when internal rates of return for education are 30-40 percent below their average estimated returns. In line with the empirical evidence, the base case assumes a partial equilibrium (social) internal rate of return (IRR) of 12 percent for investment in basic education and 10 percent for investment in upperlevel education. Many development economists reject these IRRs as too high on the grounds that they are inconsistent with the dismal scores reported for LICs in international achievement tests. We don't know whether the sceptics are right or wrong. But even if they are right, a strong case can be made for allocating a sizeable share to human capital in the optimal investment program. Lowering the IRR to 6.7 percent for investment in upper-level education and 7.6 percent for investment in basic education depresses the long-run partial equilibrium capital rentals for both investments to 15 percent, five percentage points below the capital rental for infrastructure. Large pro-growth, poverty-reducing general equilibrium externalities substantially compensate for this handicap. The share of human capital in the optimal investment program is $40-65$ percent when the social discount rate equals or exceeds 0.96 . It drops to $0-25$ percent at lower discount rates, but it bounces back up to 25 - 50 percent if education is awarded 20 basis points as a merit good in calculating the equivalent variation welfare gain.

The final section takes up the question of whether the suite of models currently on tap for policy makers needs to expand. We believe DIG-Labor 1-3 cover a lot of ground, but some countries fall between the gaps, given the complexities of their labor markets. As such, we foresee further extensions that include other labor market structures as well as health as a separate component of human capital.

Extending DIG-Labor 1-3 is consistent with the broad agenda of tailoring models to country specificities and needs. Over the years, the DIG model has been extended to incorporate other dimensions, such as an energy sector (Issoufou et al., 2014), the cost of operations and maintenance of infrastructure (Adam and Bevan, 2014), climate resilient infrastructure to address natural disaster shocks (Marto et al., 2018), and security spending (Aslam et al., 2014), among others. Special mention must be made of the extension by Atolia et al. (2019), who explore the trade-offs between investing in economic infrastructure vs. investing in social infrastructure (schools). Our results on the intertemporal trade-offs for real output and fiscal adjustment are qualitatively similar to theirs. But their model differs from our framework mainly in the specification of the labor market and the degree of structural detail they consider a representative-agent one-sector model with full employment and a single homogeneous type of labor. As mentioned before, by incorporating segmented labor markets, EWs, open unemployment, and an informal non-agricultural sector, the DIG-Labor 1-3 allow for a deeper examination of macroeconomic and fiscal policy programs and their impact on labor market outcomes, inequality, and poverty.

After the literature review in Section II, we focus solely on DIG-Labor 1. Eighty percent of the 
equations in DIG-Labor 1, however, carry over to DIG-Labor 2 and DIG-Labor 3. What differs is the specification of the labor market. We present the models for DIG-Labor 2 and DIG-Labor 3 in full and discuss their general architecture in online appendices available at http://pages.iu.edu/ ebuffie. In the case of DIG-Labor 2, we also discuss suitable parameter values for calibration of the model to MICs and EMEs.

\section{Efficiency Wages, Productivity Gaps, and Segmentation: A Short, Idiosyncratic Survey of the Literature}

Labor markets in developing countries are complicated and confusing. The empirical literature relevant to the DIG-Labor models is large and sprawls over several areas. In this section, we survey the literature, looking for answers to seven questions that determine the correct specification of the labor market.

\section{Question 1: How large is the formal sector wage premium?}

Short Answer: Very large.

Appendix A contains capsule summaries of 38 empirical estimates of the formal sector wage premium dating back to 1980. The studies differ in the type and quality of data and the extent to which they control for self selection, observable and unobservable human capital characteristics, and workplace conditions. Unsurprisingly, the results also differ. The size of the reported premium differs widely not only across countries but also across studies of the same country and even studies of the same country by the same author. While this is slightly disconcerting, the weight of the evidence argues that the formal sector wage premium is ubiquitous and large, ranging from 10 - 30 percent at the low end to 30 - 70 percent in the middle and 70 - 150 percent at the high end.

These numbers reflect a certain definition of the wage premium and a certain way of reading the literature. Many studies compute the wage premium from the coefficient on the dummy variable for formal sector employment, controlling for firm size and industry category. Typically the wage variable is the gross base wage; but it is common practice, when the data allow, to compare the wage in the informal sector to the wage net of taxes and employee social security contributions in the formal sector.

The logic behind this approach to calculating the wage premium is defensible. Controlling for firm size and industry category can help control for the impact of workplace conditions on the wage distribution. Subtracting social security contributions of employees as well as income taxes may be justified when the connection between mandatory contributions and future benefits is tenuous (e.g., 
as in universal programs) and the objective is to compare net earnings in the formal and informal sectors.

Our views on the results reported in the literature is that often they are easy to misinterpret and therefore potentially misleading. For a variety of reasons, EW models predict that large firms would pay higher wages than small firms and that industry would pay more than agriculture. ${ }^{4}$ Moreover, micro/small firms reside mainly in the informal sector and medium/large firms mainly in the formal sector. This points to the conclusion that EW effects, which operate most strongly in non-agriculture and at large firms, are the source of the wage premium. Accordingly, the formal sector wage premium should be calculated from the coefficient on the formal sector dummy and the coefficients on firm size and industry category dummies, not from the formal sector dummy alone, which captures merely the effect of formal status per se. In principle, the coefficients on firm size and industry dummies should be marked down to reflect the influence of any compensating differential paid in the formal sector for less agreeable workplace conditions. In practice, this is not necessary. As we emphasize in the answer to Question 2, the evidence suggests that workplace conditions favor the formal sector.

For models like DIG-Labor, there is another problem: with rare exceptions, empirical studies estimate one wage premium when two are needed. Much of the literature focuses on how after-tax wages vary by sector in an effort to ascertain whether firm demand is the operative constraint on employment in the formal sector. This information is valuable, but it needs to be supplemented with information from a second measure of the wage premium. Allocative efficiency depends on how the cost of labor for firms differs across the formal sector, the informal sector, and agriculture. The input required for calculation of this wage premium is the pre-tax wage plus all non-wage benefits financed by the firm, irrespective of whether employees value the benefits at one cent or one hundred cents on the dollar. Non-wage benefits matter only in the formal sector and vary considerably across the development landscape: negligible in some countries, they add up to 40 - 90 percent of the base wage in many others (e.g., Egypt, Mexico, Colombia, Brazil, India, Zimbabwe, South Africa, Panama, and Bolivia). ${ }^{5}$

A few examples may help underscore the importance of reading the results in the literature with a discerning eye. In a widely cited paper, Pratap and Quintin (2006) assert that "once we match formal sector workers with informal sector workers with similar propensity scores, the formal sector premium disappears...observably similar workers earn similar wages across sectors in Argentina." But the firm size effect alone generates a formal sector wage premium of 27.1 percent, and factoring in payroll taxes pushes the cost of labor in the formal sector 49.3 percent above that in the informal

\footnotetext{
${ }^{4}$ The incentive to pay EW is greater for large firms because management and supervision of the workforce is more difficult and the costs of labor turnover and idle equipment are higher when technology is more complex and capital intensive. See Fafchamps and Soderbom (2006) for compelling evidence of EW effects in African manufacturing.

${ }^{5}$ See Levy (2008), Ulyssea (2010), Fields (2011b), Joumard and Velez (2013), and Tansel et al. (2015).
} 
sector. Badaoui et al. (2010) take a similar line, proclaiming that in Ecuador "the formal sector wage premium is just a firm size wage differential" when comparing wages net of taxes. As do Tansel and Kan (2012): “....unobservable fixed effects when combined with controls for individual and employment characteristics explain the pay differentials between formal and informal employment entirely. The implication is remarkable....segmentation may not be a stylized fact of the Turkish labor market as previously thought." But incorporating the firm size effect and making the comparison for gross wages in Ecuador and for gross wages plus all social security contributions in Turkey delivers formal sector (employer) wage premiums of 47 percent and 72 percent, respectively. We could go on. Other examples include MacIsaac and Rama (1997), Maloney (1999), Jaffrey et al. (2006), Botelho and Ponczek (2006), Baskaya and Hulagu (2011), and Bargain and Kwenda (2014).

Question 2: Might unobservable heterogeneity in workers' characteristics and workplace conditions explain most of the large formal sector premium?

Short Answer: No, subject to the qualification that the findings of empirical economics are never fully dispositive.

Three distinct types of evidence rebut this conjecture. First, while many studies do not adequately control for the possibility that self-selection on unobservable characteristics may determine both an individual's sector of employment and their earnings, some do. Studies that exploit panel data to track the wages of individuals who move between sectors control for unobservable heterogeneity and sidestep numerous other vexing estimation issues. These studies — the gold standard in the literature - affirm that the formal sector wage premium is very large. ${ }^{6}$ To give but one example, Funkhouser (1997b) finds that the low-skill wage premium in El Salvador is 61.4 percent for females and 107 percent for males.

Second, the data for both developed and less-developed countries show very high correlations of inter-industry wage differentials across all occupations, not just occupational groups that work closely together. $^{7}$ This robust stylized fact is consistent with EW models that emphasize the connection between work effort and internal norms for fairness and horizontal equity (e.g., Akerlof, 1982), but not with the hypothesis that unobserved differences in ability and workplace conditions play a significant role in determining the formal sector wage premium - it is not credible that time and again compensating differentials would be the same for widely different occupational groups in different industries.

Third, there is a fair bit of evidence that workplace conditions are generally better in the formal

\footnotetext{
${ }^{6}$ Alvarez (2020) is a notable exception.

${ }^{7}$ In Brazil, for example, the correlation coefficient between the wage premiums for managers and security workers is an astonishing 0.896 (Abuhadba and Romaguera, 1993).
} 
sector than in the informal sector. Access to phones, electricity, restroom facilities, running water, and shelter from inclement weather; stability of income; less exposure to myriad environmental hazards; and lower injury rates all favor the formal sector. Fields (2011a) has this picture in mind when he avers that "Apart from low earnings levels and lack of social protections, a large number of jobs [in the informal sector] are downright miserable."

Assessments based on direct observation will be discounted by some as soft, unreliable data. We would disagree in this case because observations on access to running water, restroom facilities, etc., do not lend themselves to misinterpretation. Moreover, evidence from scattered pieces of hard data support Fields' assessment: (i) workers in Colombia give the formal sector much the highest scores for workplace conditions and job characteristics; ${ }^{8}$ (ii) employees at large firms in Trinidad and Tobago engage in less search on the job than employees at small firms, suggesting greater job satisfaction in the formal sector (Marcelle and Strobl, 2003); and (iii) inclusion of detailed controls for the workplace environment have either no effect or a positive effect on the formal sector wage premium in Zimbabwe (Velenchik, 1997), Peru (Schaffner, 1998), and Brazil (Arbache, 2001). ${ }^{9}$ Echoing Fields' view, Arbache observes that the positive results for Brazil "seem to be in accordance with LDC's labor market characteristics....poverty [pushes] poor people to take unpleasant and riskier jobs without being appropriately compensated."

We segue to the next question with a caveat. The case built here against compensating differentials pertains only to the comparison of wage employment in the formal sector with earnings in agriculture and wage employment in the informal sector; the comparison vis à vis self-employment in the informal sector is less clear-cut.

Question 3: How heterogeneous is the informal sector? More specifically, does the formal sector wage premium vary significantly vis-à-vis different segments of the informal sector? Short Answer: It depends on the country in question.

The informal sector is heterogeneous. It comprises, at a minimum, two distinct segments: salaried workers and the self-employed (owners of micro enterprises, independent professionals, and ownaccount workers). The relative importance of the two segments varies considerably from one developing country to the next. Self-employment accounts for 70 - 90 percent of informal employment in most LICs. In MICs and EMEs the two segments are of equal size or wage employment predominates.

\footnotetext{
${ }^{8}$ The findings in the special module on Quality of Employment in Colombia's 1994 National Household Survey are discussed in Goldberg and Pavcnik (2003).

${ }^{9}$ The United States can be added to the list of countries where the hedonic wage premium is larger than the nonhedonic premium (Krueger and Summers, 1987 and 1988). This will come as no surprise to anyone who has read Barbara Ehrenreich's Nickle and Dimed (2001).
} 
Typically, salaried workers in the informal sector strongly prefer employment in the formal sector, where pay is much higher and workplace conditions much better. For the self-employed, the results are more mixed. According to labor force surveys for Latin America and the Caribbean, the majority of the self-employed do not seek jobs in the formal sector; they work voluntarily in the informal sector in order to maximize earnings and/or enjoy greater independence (Maloney, 1999, 2002, 2004; Bosch and Maloney, 2007; Perry et al., 2007). This two-tiered structure also seems to describe the informal labor market in Côte d'Ivoire (Gunther and Launov, 2012).

But the separation between the two tiers is far from clean. Thirty percent of the self-employed in the aforementioned surveys for Latin American and Caribbean prefer employment in the formal sector. In Colombia and Turkey, the self-employed are no better off than wage employees in the informal sector, and in Ethiopia, Malawi, Tanzania, Uganda, South Africa, and Ghana they earn considerably less (Perry et al., 2007; Ben Salem and Bensidoun, 2012; McCullough, 2017; Heintz and Slonimcyzek, 2007; Heintz and Posel, 2008). Although hard data is lacking elsewhere, the consensus among informed observers is that, outside of four or five countries in Latin America, work in the informal sector is a desperate strategy-of-last-resort for both the self-employed and wage employees:

"The enterprises of the poor often seem more a way to buy a job when a more conventional employment opportunity is not available than a reflection of a particular entrepreneurial urge. Many of the businesses are run because someone in the family has (or is believed to have) some time on hand and every little bit helps....the many businesses of the poor are less a testimony to their entrepreneurial spirit than a symptom of the dramatic failure of the economies in which they live to provide them with something better." (Banerjee and Duflo, 2011)

"Many informal entrepreneurs would gladly close their businesses to work as employees in the formal sector if offered the choice." (La Porta and Shleifer, 2014)

"Typically, the better jobs are in wage employment, not self-employment....The problem the poor face is that not enough regular wage employment is available for all who would like jobs and are capable of performing them." (Fields, 2011a)

\section{Question 4: How strong is the evidence for EWs in the formal sector?}

\section{Short Answer: Very strong.}

Over the past 20 years, empirical studies have amassed abundant, compelling evidence that EWs operate throughout the formal sector in less-developed countries (LDCs). Estimates of the impact of unemployment on real wages confirm the existence of wage curves in Argentina, Turkey, Colombia, Uruguay, Chile, South Africa, Côte d'Ivoire, Mexico, China, South Korea, and a host of other LDCs 
(Blanchflower and Oswald, 2005). There is also powerful, if indirect, evidence supportive of EWs in the stylized facts documented in microeconomic studies of developing country labor markets. Across the development spectrum, wage and employment data exhibit the same patterns: (i) firm-size wage premiums that start at very small establishment size $(5+$ employees $)$ and are much larger than in developed countries; (ii) persistent, remarkably stable inter-industry wage differentials; (iii) high correlation of industry wage premiums across occupations; (iv) large wage premia for formal vs. informal sector employment and for informal non-agricultural employment vs. agricultural employment; (v) large cyclical flows into and out of unemployment in both the formal sector and the informal sector; (vi) virtually identical lists for low- and high-paying industries; (vii) large, stable wage differentials between firms in the same industry; (viii) payment of higher wage premiums in capital-intensive industries; and (ix) lower quit rates and longer job tenure in the formal sector. At present, only EW models can explain all of these stylized facts. Competing theories cannot be ruled out altogether the sheer number and diversity of LDCs precludes that - but none come close the explanatory power of EW. ${ }^{10}$

\section{Question 5: Are there EWs in the informal sector?}

\section{Short Answer: Yes, but only in the wage-employment sub-sector.}

We need to elaborate on some of the empirical evidence cited in support of EW in the answer to Question 4:

- Appendix B collects estimates of wage curves that relate the level of the real wage to the unemployment rate in LDCs. Clearly, wage curves are not confined to the formal sector; they also operate in the informal sector. This does not mean that wages are equally rigid in the two sectors. The common perception that wages are more flexible in the informal sector is correct. Most studies find that wages in the informal sector are more responsive to the unemployment rate than wages in the formal sector. But a large gap separates more responsive from highly responsive. The informal sector does not approximate a frictionless buffer sector with flexible, market-clearing wages.

- The firm size effect kicks in very quickly, starting at micro enterprises with 2-5 employees (Velenchik, 1997; Schaffner, 1998; Badaoui et al., 2010).

- If wages are rigid in the informal sector, the data should show large movements into and out of unemployment during booms and recessions. This is precisely what Bosch and Maloney (2007)

\footnotetext{
${ }^{10}$ Mixed models are relevant in some countries. EW effects can explain the many puzzling stylized facts associated with minimum wage increases in less-developed countries. We would also argue that optimizing union models should incorporate EW effects.
} 
find in their study of labor market dynamics in Mexico, Argentina, and Brazil. ${ }^{11}$ Salaried jobs in the informal sector showed high rates of separation toward unemployment and inactivity (i.e., dropping out of the labor force). In fact, in all three countries transitions out of informal sector employment contributed much more to unemployment than transitions out of formal sector employment. In Mexico, for example, transitions into unemployment from salaried informal employment were three times greater than transitions from formal employment; equally striking, none of the workers laid off in the formal sector found jobs in the informal sector - entry from the formal into the informal sector declined during downturns.

- For at least one important country, there is strong, direct evidence of job rationing in the informal sector. In labor force surveys in South Africa, 80 percent of the unemployed reported that they could not find any work; only three percent cited an inability to find "suitable work" as the reason for being unemployed (Heinz and Posel, 2008). Several other studies corroborate the survey findings. Nattras and Walker (2005) and Burger and Schotte (2017) estimate that the reservation wage of the unemployed is far below their predicted earnings and link their results to data showing a shortage of job offers is the principal cause of unemployment; job refusals are rare. Kingdon and Knight (2004) present data affirming that the unemployed are substantially worse off than the employed in the informal sector in income, consumption, and various indicators of non-economic well-being.

- Labor force participation rates are implausibly low in much of Sub-Saharan Africa (Falco et al., 2011; Teal, 2014). The most plausible explanation is that discouraged workers, who cannot find a job even in the informal sector, are misclassified as "out of the labor force."

Our brief includes one more bullet point. The puzzling stylized facts associated with minimum wages in LDCs are highly informative about the nature of wage determination in the informal sector:

- For a long time, conventional wisdom subscribed to a simple, intuitively appealing account of the repercussions of raising the minimum wage, to wit: employment decreases in the formal sector; some of the laid-off workers seek jobs in the informal sector; ergo employment increases and the real wage falls in the informal sector. But then the facts showed up and ruined a good story. The narrative goes badly wrong when it shifts to the impact on the informal sector. Sometimes employment increases in the informal sector; normally, however, it decreases more than employment in the formal sector (Betcherman, 2014). The real wage in the informal sector does not decline; reflecting the ubiquitous "lighthouse effect," it almost always increases (Gindling, 2014). These results are difficult — maybe impossible — to reconcile with a competitive, flex-wage view

\footnotetext{
${ }^{11}$ Berg and Contreras (2004) supply evidence for Chile. Neri (2002) and Ulyssea (2010) provide additional evidence for Brazil.
} 
of the labor market, but they make perfect sense if firms in the informal sector pay EW and the minimum wage shifts the norm for fairness among workers (Adam and Buffie, 2020).

At the risk of belaboring the obvious, we note that self-employed workers do not pay themselves an EW. In the self-employment segment of the informal labor market, the "wage" is an implicit payment for labor services and perfectly flexible. The need for multiple DIG-Labor models stems from this and the tremendous variation in the weight of the self-employed in informal sector employment. DIGLabor 1 and DIG-Labor 3 posit flexible wages in the informal sector. One or the other is appropriate for countries where informal employment is largely synonymous with self-employment. For countries where wage employment predominates in the informal sector, we recommend DIG-Labor 2, although users who believe wages are flexible across the informal sector will choose DIG-Labor 1 or DIG-Labor 3.

Question 6: Is the marginal value product of labor lower in agriculture than in the informal sector?

Short Answer: Probably.

Empirical studies of structural transformation and the economic returns to migration from agriculture to non-agricultural work speak to this question. The literature on both suggests that reallocation of labor from agriculture to other sectors - including the informal sector — generates large increases in aggregate labor productivity. The reason for hedging with "suggests" in the preceding sentence and with "probably" in the Short Answer is that doubts persist about the reliability of the data and the correct interpretation of the results.

The literature on structural transformation decomposes increases in aggregate labor productivity into within- and between-sector effects. For illustrative purposes, divide the economy into agriculture and non-agriculture (distinguished by subscripts $a$ and $n$ ). Let $L_{i}$ and $Y_{i}$ denote employment and value added in sector $i$. Aggregate labor productivity is then

$$
\frac{Y}{L}=\frac{Y_{n}+Y_{a}}{L}
$$

which can be expressed as

$$
\frac{Y}{L}=\frac{Y_{n}}{L_{n}} \ell_{n}+\frac{Y_{a}}{L_{a}} \ell_{a}
$$

where $L=L_{a}+L_{n}$ is total labor supply and $\ell_{i}=L_{i} / L$ is the share of employment in sector $i$.

Misallocation in the labor market depends on the gap in sectoral marginal value products of labor $\left(M V P L_{i}\right)$. From (1),

$$
\frac{d(Y / L)}{Y / L}=\underbrace{\frac{M V P L_{n}-M V P L_{a}}{Y / L} d \ell_{n}}_{\text {True Between-Sector Effect }}+\text { Within-Sector Effect. }
$$


where the Within-Sector Effect is calculated as a residual.

The structural transformation literature takes a different approach, focusing instead on the gap in sectoral labor productivity. Simple manipulation of (2) yields

$$
\frac{d(Y / L)}{Y / L}=\underbrace{\frac{Y_{n} / L_{n}-Y_{a} / L_{a}}{Y / L} d \ell_{n}}_{\text {Between-Sector Effect }}+\underbrace{\frac{\ell_{n} d\left(Y_{n} / L_{n}\right)+\ell_{a} d\left(Y_{a} / L_{a}\right)}{Y / L}}_{\text {Within-Sector Effect }} .
$$

To connect (4) to the theoretically correct decomposition in (3), assume labor is paid its marginal value product $(M V P)$ so that

$$
\frac{M V P L_{i}}{Y_{i} / L_{i}}=\theta_{i} \quad \Longrightarrow \quad \frac{M V P L_{n}}{M V P L_{a}}=\frac{\theta_{n}}{\theta_{a}} A P G,
$$

where $\theta_{i} \equiv w_{i} L_{i} / Y_{i}$ is the cost share of labor in value added and $A P G \equiv\left(Y_{n} / L_{n}\right) /\left(Y_{a} / L_{a}\right)$ is the agricultural productivity gap.

Clearly, the Between-Sector Effect in (4) is not an exact measure of the contribution of structural transformation to growth in aggregate labor productivity. In practice, however, it is an acceptable approximation. The data place $\theta_{n}$ around 0.5 and $\theta_{a}$ between 0.45 and 0.60 (see Section IV). The measurement error associated with the adjustment factor $\theta_{n} / \theta_{a}$ deviating from unity is not trivial, but the bias could go in either direction and is small relative to most estimates of $A P G$. In the meticulous, authoritative study conducted by Gollin et al. (2014), which controls for home production in agriculture, for differences in the cost of living and urban vs. rural amenities, and for sector differences in hours worked and in human capital acquired from experience and schooling, the mean APG for the poorest quartile of countries is three. Caselli (2005) and Restuccia et al. (2008) also present evidence of very large $A P G s$. Until recently, therefore, there was general agreement that labor productivity in agriculture is much lower than in non-agriculture and hence that the potential gains from structural transformation are large, especially in LICs. Back in 2014, in their introduction to a special issue of World Development on Understanding Structural Transformation in Africa, McMillan and Heady (2014) could follow the observation that

"The question underlying all this literature is why quasi-subsistence agriculture is so pervasive in poor countries, particularly since rural areas seem to be very poor and unproductive relative to urban areas."

with the strong, confident assertion that

"There is thus a potential for enormous economic gain in African countries from reallocating activity from low to high productivity sectors. The next set of papers in this special issue present evidence of significant untapped opportunities for structural change in Africa." 
That was then. Today the case for large gains from structural transformation is under a cloud of indeterminate size. Two recent papers challenge the view that the $A P G$ is large on the grounds that the datasets in Gollin et al. (2014) and a host of other studies rely on labor force surveys that greatly overstate hours worked in agriculture.

Arthi et al. (2018) test for recall bias in the Mara region of Tanzania by comparing labor input reported in weekly visits (presumed accurate) with labor input reported after the harvest (the practice in most agricultural surveys). The disparity in the answers is disturbing. Households surveyed after the harvest reported hours worked per person per plot 3 - 3.7 times greater than hours reported by households surveyed weekly. On the basis of this finding, the authors conclude that previous studies greatly exaggerate the $A P G$.

But households surveyed at the end of the agricultural season also underreport the number of family members engaged in farming by 33 percent and the number of plots cultivated by 47 percent. After adjusting for these offsetting errors, overreporting of labor hours decreases to 8.1 percent. The authors counter that the overlooked plots are likely to be marginal plots and the overlooked family members working in farming more likely to be children. This is probably true. But we do not know for sure. And even if the conjectures were known to be true, we do not know how much weight they carry in the calculation of total labor input. Long-period recall data understate labor productivity, but the magnitude of the bias is unknown.

McCullough (2017) provides further evidence that standard labor force surveys substantially overstate hours worked in agriculture. Armed with new rich micro-level household surveys, she decomposes the gap in output per worker $(G A P)$ in Ethiopia, Malawi, Tanzania, and Uganda into the product of the productivity gap $(P G A P)$ and the employment gap $(E G A P)$ :

$$
\frac{Y_{n} / L_{n}}{Y_{a} / L_{a}}=\left(\frac{Y_{n} / H_{n}}{Y_{a} / H_{a}}\right)\left(\frac{H_{n} / L_{n}}{H_{a} / L_{a}}\right) \Longrightarrow G A P=P G A P \times E G A P,
$$

where $H$ is hours worked, $P G A P \equiv\left(Y_{n} / H_{n}\right) /\left(Y_{a} / H_{a}\right)$, and $E G A P \equiv\left(H_{n} / L_{n}\right) /\left(H_{a} / L_{a}\right) \cdot{ }^{12}$

The decomposition in (6) reveals tremendous underemployment in agriculture. EGAP ranges from 2.1 in Uganda to 3.3 in Malawi and explains the majority of GAP. McCullough concludes that the results "call into question the productivity gains that laborers can achieve through structural transformation."

But again, the headline exaggerates. The average productivity gap in the four countries is 1.58. This is barely half the value for Sub-Saharan Africa in Gollin et al. (2014), but still large in absolute

\footnotetext{
${ }^{12}$ We have changed notation here. In equations (1)-(5), $L_{a}$ and $L_{n}$ refer to employment adjusted for differences in hours worked in sectors $a$ and $n$. In equation (6), they refer to the number of employed workers.
} 
terms. Moreover, Ethiopia is a distinct outlier in both Gollin et al.'s and McCullough's datasets. The average productivity gap in Malawi, Uganda, and Tanzania is 1.82 .

We have discussed this part of the literature in detail because the number for the $A P G$ has important implications for the size of the productivity gap between the informal sector and agriculture. None of the studies cited earlier compute separate APGs for the formal and informal sectors. But the aggregate $A P G$ together with estimates of the formal sector wage premium can be used to tease out guesstimates of the $A P G$ and $M V P L$ gap for the informal sector component of non-agriculture. Return to (1) and replace $Y_{n}$ and $L_{n}$ with $Y_{f}+Y_{j}$ and $L_{f}+L_{j}$, where subscripts $f$ and $j$ refer to the formal and informal sectors. By definition,

$$
A P G \equiv \frac{\left(Y_{f}+Y_{j}\right) /\left(L_{f}+L_{j}\right)}{Y_{a} / L_{a}} \Longrightarrow A P G=\left(\frac{Y_{f} / L_{f}}{Y_{j} / L_{j}}\right)\left(\frac{Y_{j} / L_{j}}{Y_{a} / L_{a}}\right) \frac{L_{f}}{L_{f}+L_{j}}+\left(\frac{Y_{j} / L_{j}}{Y_{a} / L_{a}}\right) \frac{L_{j}}{L_{f}+L_{j}} .
$$

Let $\ell_{j} \equiv L_{j} /\left(L_{j}+L_{f}\right), P G A P_{f j} \equiv\left(Y_{f} / L_{f}\right) /\left(Y_{j} / L_{j}\right)$, and $P G A P_{j a} \equiv\left(Y_{j} / L_{j}\right) /\left(Y_{a} / L_{a}\right)$ denote respectively the share of the informal sector in non-agricultural employment, the productivity gap between the formal and informal sector, and the productivity gap between the informal sector and agriculture. With this notation,

$$
P G A P_{j a}=\frac{A P G}{\ell_{j}+\left(1-\ell_{j}\right) P G A P_{f j}} \Longrightarrow \frac{M V P L_{j}}{M V P L_{a}}=\left(\frac{\theta_{j}}{\theta_{a}}\right) \frac{A P G}{\ell_{j}+\left(1-\ell_{j}\right) P G A P_{f j}} .
$$

Consider a LIC where $\lambda_{j}=0.8, P G A P_{f j}=2$, and $\theta_{j} / \theta_{a}=0.8-1$. For $A P G=3$, the mean value for the poorest quartile of countries in Gollin et al. (2014), equation (8) returns $M V P L_{j} / M V P L_{a}=$ $2-2.5$. This is much too large. In line with the critiques in Arthi et al. (2018) and McCullough (2017), an $A P G$ of three overstates the agricultural productivity gap. An $A P G$ of two, on the other hand, works quite well. The range for the $M V P L$ gap, 1.33 - 1.67, is consistent with the estimated earnings gaps of 46 percent, 39 - 46 percent, and 30 percent between informal wage employment and agricultural self-employment in Ghana, South Africa, and Turkey (Heintz and Slonimczyk, 2007; Heintz and Posel, 2008; Baskaya and Hulagu, 2011); with the 41 percent consumption gain for individuals who moved from agricultural to non-agricultural work in Beegle et al.'s (2011) tracking study of migration in Tanzania; and with the sizeable fraction of increased labor productivity in Vietnam and Tanzania attributable to reallocation of labor from agriculture to informal employment (McCaig and Pavnik, 2013; Diao et al., 2018).

The Catch: As usual, there is a catch. EW can explain the productivity gap between the formal sector and agriculture. But what explains the $M V P L$ gap between the informal sector and agriculture? If the gap is truly large, then why isn't there more rural-urban migration (De Brauw et al., 2014; Christiaensen and Todo, 2014)? Why doesn't arbitrage eliminate most or all of the MVPL gap? 
Development labor economists have struggled to answer these questions. Beegle et al. (2011) conjecture that social and family norms act as "exit barriers" to migration. Gollin and Rogerson (2011)

hypothesize that transportation and transactions costs are exit barriers. In Bryan et al. (2012), risk aversion interacting with information asymmetries deters migration. McCullough (2017) suggests that low work hours in agriculture reflect a combination of low labor demand outside of agriculture and "biophysical constraints" that limit the potential for productive work in agriculture. But the suggestion is not exactly wrapped in confidence: "It is important to better understand the reasons for low labor supply by agricultural workers....underemployment in agriculture is not a well understood phenomenon." Young (2013) denies that labor markets are inefficient, arguing that the large sectoral MVPL gaps are explained by sorting of high-ability workers into non-agriculture and low-ability workers into agriculture. Gollin et al. (2014) take the position in some places that large APGs "suggest labor is misallocated across sectors, and particularly in developing countries," with the implication that "there should be large income gains from workers moving out of agriculture and into other economic activities." But they also contend that the selection-on-unobserved-ability models in Lagakos and Waugh (2013) and Young (2013) "provide an important path toward understanding the productivity gaps" documented in the paper. A strange about-face, for the import of the selection-on-unobserved-ability hypothesis is that labor markets are fully efficient and the alleged productivity gaps not real; evidently the authors are not of one mind about how to interpret their results.

One of these conjectures may prove correct in the end. At present, however, the literature is in disarray. The confused bottom line — "We don't know what we have here" — invites scepticism and distrust of the empirical results.

Predictably, we believe the empirical results are genuine and that the DIG-Labor models offer good, albeit imperfect, explanations for them. In DIG-Labor 2, EWs in the informal sector can explain why earnings and the $M V P L$ are higher than in agriculture. This explanation is not available in DIG-Labor 1 and 3, which assume that the informal sector and agriculture form an integrated labor market with flexible wages. But though labor mobility equalizes earnings in the two sectors, the $M V P L$ gap is large because labor's remuneration in agriculture includes a share of land rents. All of the DIG-Labor models are compatible therefore with the stylized fact that structural transformation increases aggregate labor productivity when labor reallocates from agriculture to either the formal or informal sector in non-agriculture.

Question 7: How much involuntary unemployment exists in less-developed countries (LDCs)?

Short Answer: A lot, especially in urban areas.

Table 2 lists unemployment rates in various LDCs. In the most common case, high unemployment 
rates are confined to urban areas. But there are plenty of exceptions - cases where national, rural, and urban unemployment rates are all north of 10 percent.

What exactly do the high unemployment rates measure? In earlier periods one could discount the possibility that they measure involuntary unemployment by appealing to studies supportive of the "luxury unemployment" hypothesis: labor force surveys from the 1960s and 1970s revealed that the unemployed were predominantly young, relatively well-educated dependents from families with aboveaverage incomes (Udall and Sinclair, 1982; Berry and Sabot, 1978, 1984). This view still commands support in some quarters (e.g., Fields, 2011a; Fox et al., 2013) even though unemployment rates in urban areas and for the young have risen to levels that seem inexplicable if most unemployment is voluntary in nature. ${ }^{13}$ The point in dispute concerns the meaning of involuntary unemployment, a term that is inherently ill-defined in countries with segmented labor markets. Elaborating by way of example, suppose the wage is $\$ 100$ a week in the formal sector and $\$ 50$ a week in the informal sector. If the unemployed have a reservation wage above $\$ 100$ a week, they should be counted as voluntarily unemployed - as out of the labor force. But this is rarely the case. Both proponents and critics of the luxury unemployment hypothesis agree that the unemployed seek work in the high-wage formal sector while refusing jobs available in the flex-wage informal sector (or agriculture). This implies that the reservation wage of the unemployed lies somewhere between $\$ 50$ and $\$ 100$, say $\$ 70$. The adjective attached to unemployment depends therefore on the point of comparison for the reservation wage. Unemployment is voluntary when the reference point is the informal wage, but involuntary when it is the formal sector wage. ${ }^{14}$

In our view, this is pointless semantic quibbling. Whether the unemployment is labeled voluntary or involuntary is unimportant. What is important is that reductions in unemployment in EW models generate significant welfare gains. In an integrated labor market, when the wage rises from $\$ 100$ to $\$ 100.01$ and one more person goes to work, the welfare gain from the decrease in voluntary unemployment is second-order small. By contrast, in our example, the gain is first-order large. The term luxury unemployment is analytically and descriptively wrong. It should be taken out of circulation.

\section{The DIG-Labor 1 Model}

DIG-Labor 1 has three sectors, multiple types of public sector debt, and a wide array of tax and spending variables. The economy produces a composite traded good and two non-traded goods. The

\footnotetext{
${ }^{13}$ Turnham (1993) was calling attention to the new empirical reality twenty-six years ago.

${ }^{14}$ This ambiguity fuels part of the debate in developed countries between New Classical and New Keynesian macroeconomists. Robert Lucas articulates the case for the New Classical view that unemployment in EW models is voluntary because "however miserable one's current work options, one can always choose to accept them" (Lucas, 1981). The proffered rationale is baffling, to put it mildly. All unemployment is voluntary because McDonald's is always hiring?
} 
traded good is the numeraire and $x, j$, and $n$ subscripts refer to the tradables sector, the informal non-tradables sector, and the formal non-tradables sector. All quantity variables except labor and land are detrended by $(1+\mathfrak{g})^{t}$, where $\mathfrak{g}$ is the exogenous long-run growth rate of per capita income. To fix ideas, we refer to sector $x$ as agriculture.

The exposition of the model follows the outline of DIG in Buffie et al. (2012) and Zanna et al. (2019).

\section{A. Technology}

\section{A.1. Production Functions}

Firms convert inputs into output via Cobb-Douglas production functions:

$$
\begin{aligned}
& q_{x, t}=a_{x} z_{t-1}^{\psi_{x}} k_{x, t-1}^{\alpha_{x}} S_{x, t}^{\theta_{x}} H^{\chi}\left(e_{b, t} L_{x, t}\right)^{1-\alpha_{x}-\theta_{x}-\chi}, \\
& q_{n, t}=a_{n} z_{t-1}^{\psi_{n}} k_{n, t-1}^{\alpha_{n}} S_{n, t}^{\theta_{n}}\left(e_{n, t} e_{b, t} L_{n, t}\right)^{\left(1-\alpha_{n}-\theta_{n}\right)},
\end{aligned}
$$

and

$$
q_{j, t}=a_{j} z_{t-1}^{\psi_{j}} k_{j, t-1}^{\alpha_{j}} S_{j, t}^{\theta_{j}}\left(e_{b, t} L_{j, t}\right)^{\left(1-\alpha_{j}-\theta_{j}\right)} .
$$

All sectors utilize capital $k$, low-skill labor $L$, high-skill labor $S$, and government-supplied infrastructure $z$. Infrastructure is a public good that enhances productivity in all sectors, and land or some natural resource $H$ is a sector-specific input in sector $x$. The variable $e_{b}$ links the quantity and quality of primary education to human capital of low-skill labor. In the formal sector, where EW considerations apply, the productivity of low-skill labor also depends on work effort $e_{n}$.

Education capital is of two types, $S_{b}$ for basic education (primary + lower secondary) and $S_{u}$ for upper-level education (upper secondary + tertiary). Factories, infrastructure, and education capital are built by combining $a_{i m}$ imported machines with $a_{i n}$ and $a_{i j}\left(i=k, z, S_{u}, S_{b}\right)$ units of formal and informal sector inputs. The supply prices of $k, z$, and $S_{u} / S_{b}$ are thus

$$
P_{k, t}=a_{k m}+a_{k n} P_{n, t}+a_{k j} P_{j, t}, \quad P_{z, t}=a_{z m}+a_{z n} P_{n, t}+a_{z j} P_{j, t}, \quad \text { and } \quad P_{s, t}=a_{s m}+a_{s n} P_{n, t}+a_{s j} P_{j, t} .
$$

\section{A.2. Factor Demands}

Competitive firms maximize profits by hiring each input up to the point at which its MVP equals its price:

$$
\left(1-\alpha_{x}-\theta_{x}-\chi\right) \frac{q_{x, t}}{L_{x, t}}=w_{x, t}, \quad \theta_{x} \frac{q_{x, t}}{S_{x, t}}=w_{s, t}, \quad \alpha_{x} \frac{q_{x, t}}{k_{x, t-1}}=r_{x, t}, \quad \chi \frac{q_{x, t}}{H}=r_{h, t},
$$




$$
\begin{gathered}
P_{n, t}\left(1-\alpha_{n}-\theta_{n}\right) \frac{q_{n, t}}{L_{n, t}}=w_{n, t}, \quad P_{n, t} \theta_{n} \frac{q_{n, t}}{S_{n, t}}=w_{s, t}, \quad P_{n, t} \alpha_{n} \frac{q_{n, t}}{k_{n, t-1}}=r_{n, t}, \\
P_{j, t}\left(1-\alpha_{j}-\theta j\right) \frac{q_{j, t}}{L_{j, t}}=w_{j, t}, \quad P_{j, t} \theta_{j} \frac{q_{j, t}}{S_{j, t}}=w_{s, t}, \quad \text { and } \quad P_{j, t} \alpha_{j} \frac{q_{j, t}}{k_{j, t-1}}=r_{j, t},
\end{gathered}
$$

where $w_{s}$ is the skilled wage, $r_{h}$ is the land rent, and $w_{i}$ and $r_{i}$ are the low-skill wage and the capital rental in sector $i$. Skilled labor is intersectorally mobile, so the same wage appears in the equations (13) - (15) that involve the MVP of $S_{x, t}, S_{n, t}$ and $S_{j, t}$. Capital is sector specific, but the capital rentals differ only on the transition path. In the long run, after adjustment is complete, $r_{x}=r_{n}=r_{j}$.

A detailed discussion of the low-skill labor market follows in a couple of pages. For now, we note two points in connection with the equations that involve real wages in (13) - (15). First, the market is segmented, with $w_{n}>w_{j} \geq w_{x}$ and rationing of jobs in the high-wage formal sector. Second, $w_{x}$ does not necessarily correspond to earnings of low-skill labor in sector $x$; in countries with smallholder agriculture and insecure land rights, $w_{x}$ should be interpreted as the shadow wage of labor.

\section{B. Preferences}

\section{B.1. Household Optimization Problems}

There are two types of private agents, non-savers and savers (distinguished by subscripts 1 and 2). Preferences of both agents qua consumers are given by

$$
\begin{gathered}
c=\left[\kappa_{1}^{1 / \varepsilon_{1}} c_{x}^{\left(\varepsilon_{1}-1\right) / \varepsilon_{1}}+\left(1-\kappa_{1}\right)^{1 / \varepsilon_{1}} c_{f j}^{\left(\varepsilon_{1}-1\right) / \varepsilon_{1}}\right]^{\varepsilon_{1} /\left(\varepsilon_{1}-1\right)}, \\
c_{f j}=\left[\kappa_{2}^{1 / \varepsilon_{2}} c_{n m}^{\left(\varepsilon_{2}-1\right) / \varepsilon_{2}}+\left(1-\kappa_{2}\right)^{1 / \varepsilon_{2}} c_{j}^{\left(\varepsilon_{2}-1\right) / \varepsilon_{2}}\right]^{\varepsilon_{2} /\left(\varepsilon_{2}-1\right)},
\end{gathered}
$$

and

$$
c_{n m}=\left[\kappa_{3}^{1 / \varepsilon_{3}} c_{n}^{\left(\varepsilon_{3}-1\right) / \varepsilon_{3}}+\left(1-\kappa_{3}\right)^{1 / \varepsilon_{3}} c_{m}^{\left(\varepsilon_{3}-1\right) / \varepsilon_{3}}\right]^{\varepsilon_{3} /\left(\varepsilon_{3}-1\right)}
$$

where $c_{i}$ is consumption of good $i$. The bottom tier defines $c_{n m}$ as a CES aggregate of $c_{n}$ and consumption $c_{m}$ of an imported consumer good. In the middle tier, $c_{f j}$ is a CES aggregate of $c_{n m}$ and $c_{j}$. At the upper tier, $c_{f j}$ combines with $c_{x}$ in another CES function.

Three-tiered CES utility functions are not seen every day in macroeconomic models. The importance of working with a flexible, general specification of preferences will become clear in due course.

The representative agents choose $c_{i}(i=n, m, x, j)$ to minimize the cost of purchasing $c$ at prices $P_{n}(1+h), P_{j}\left(1+g_{j} h\right), 1+g_{m} h$, and $1+g_{x} h$, where $h$ is the VAT tax in the formal sector, $g_{m} \geq 1$, and $g_{x}, g_{j} \leq 1$ determine the reach of the tax net in sectors $j$ and $x$. This yields the set of demand functions

$$
c_{n, t}=\kappa_{3}\left[\frac{\left(1+h_{t}\right) P_{n, t}}{P_{n m, t}}\right]^{-\varepsilon_{3}} \kappa_{2}\left(\frac{P_{n m, t}}{P_{f j, t}}\right)^{-\varepsilon_{2}}\left(1-\kappa_{1}\right)\left(\frac{P_{f j, t}}{P_{c, t}}\right)^{-\varepsilon_{1}}\left(c_{1, t}+c_{2, t}\right),
$$




$$
\begin{gathered}
c_{j, t}=\left(1-\kappa_{2}\right)\left[\frac{\left(1+g_{j} h_{t}\right) P_{j, t}}{P_{f j, t}}\right]^{-\varepsilon_{2}}\left(1-\kappa_{1}\right)\left(\frac{P_{f j, t}}{P_{c, t}}\right)^{-\varepsilon_{1}}\left(c_{1, t}+c_{2, t}\right), \quad g_{j} \leq 1, \\
c_{x, t}=\kappa_{1}\left(\frac{1+g_{x} h_{t}}{P_{c, t}}\right)^{-\varepsilon_{1}}\left(c_{1, t}+c_{2, t}\right), \quad g_{x} \leq 1,
\end{gathered}
$$

and

$$
c_{m, t}=\left(1-\kappa_{3}\right)\left[\frac{1+g_{m} h_{t}}{P_{n m, t}}\right]^{-\varepsilon_{3}} \kappa_{2}\left(\frac{P_{n m, t}}{P_{f j, t}}\right)^{-\varepsilon_{2}}\left(1-\kappa_{1}\right)\left(\frac{P_{f j, t}}{P_{c, t}}\right)^{-\varepsilon_{1}}\left(c_{1, t}+c_{2, t}\right),
$$

and the associated price indices

$$
\begin{gathered}
P_{c, t}=\left[\kappa_{1}\left(1+g_{x} h_{t}\right)^{1-\varepsilon_{1}}+\left(1-\kappa_{1}\right) P_{f j, t}^{1-\varepsilon_{1}}\right]^{1 /\left(1-\varepsilon_{1}\right)} \\
P_{f j, t}=\left\{\kappa_{2} P_{n m, t}^{1-\varepsilon_{2}}+\left(1-\kappa_{2}\right)\left[\left(1+g_{j} h_{t}\right) P_{j, t}\right]^{1-\varepsilon_{2}}\right\}^{1 /\left(1-\varepsilon_{2}\right)}, \\
P_{n m, t}=\left\{\kappa_{3}\left[\left(1+h_{t}\right) P_{n, t}+\left(1-\kappa_{3}\right)\left(1+g_{m} h_{t}\right)^{1-\varepsilon_{3}}\right]^{1-\varepsilon_{3}}\right\}^{1 /\left(1-\varepsilon_{3}\right)}, \\
P_{t}=\left[\kappa_{1}+\left(1-\kappa_{1}\right) \mathbb{P}_{f j, t}^{1-\varepsilon_{1}}\right]^{1 /\left(1-\varepsilon_{1}\right)}, \\
\mathbb{P}_{f j, t}=\left[\kappa_{2} \mathbb{P}_{n m, t}{ }^{1-\varepsilon_{2}}+\left(1-\kappa_{2}\right) P_{j, t}^{1-\varepsilon_{2}}\right]^{1 /\left(1-\varepsilon_{2}\right)}
\end{gathered}
$$

and

$$
\mathbb{P}_{n m, t}=\left[\kappa_{3} P_{n, t}^{1-\varepsilon_{3}}+1-\kappa_{3}\right]^{1 /\left(1-\varepsilon_{3}\right)}
$$

$P_{c}$ is the price index for aggregate consumption, inclusive of VAT taxes. For later use, we also record the exact consumer price index $P$.

Unemployed individuals $L_{\mathfrak{u}}$ and low-skill workers in sectors $x$ and $j$ live hand-to-mouth, consuming all of their income each period. The group's share in transfer payments $\mathcal{T}$ handed out by the government equals its share in the labor force $L$, and labor's earnings in agriculture may include a share of land rents. Hence the budget constraint of the representative non-saver is

$$
P_{c, t} c_{1, t}=\left(1-f_{w x}\right)\left(w_{x, t} L_{x, t}+\sigma r_{h} H\right)+\left(1-f_{w j}\right) w_{j, t} L_{j, t}+a_{t} \mathcal{T}_{t}
$$

where

$$
a_{t}=\frac{L_{x, t}+L_{j, t}+L_{\mathfrak{u}, t}}{L}, \quad L=\bar{L}+S, \quad \bar{L}=L_{x}+L_{n}+L_{j}+L_{\mathfrak{u}},
$$

$S$ is the supply of skilled labor, $\bar{L}$ is the supply low-skill labor, $f_{w j}$ and $f_{w x}$ are ad valorem taxes on low-skill wage income, and $\sigma>0$ in the case of smallholder agriculture. ${ }^{15}$

Capitalists, skilled labor, and low-skill labor in the formal sector (sector $n$ ) comprise the saving class. They maximize

$$
V=\sum_{t=0}^{\infty} \beta^{t} \frac{c_{2, t}{ }^{1-1 / \tau}}{1-1 / \tau},
$$

\footnotetext{
${ }^{15} 0<\sigma<1$ when sector $x$ comprises smallholder agriculture and other sectors (e.g., estate agriculture, mining, sharecroppers).
} 
subject to

$$
\begin{aligned}
P_{t} b_{t}-b_{f, t}= & \left(1-f_{w}\right)\left(w_{n, t} L_{n, t}+w_{s, t} S_{t-1}\right)+\sum_{\mathfrak{q}=j, n, x}\left[r_{\mathfrak{q}, t}-f_{\mathfrak{q}}\left(r_{\mathfrak{q}, t}-\delta P_{\mathfrak{q}, t}\right)\right] k_{\mathfrak{q}, t-1} \\
& +\left(1-f_{h}\right)(1-\sigma) r_{h, t} H+\left(1-a_{t}\right) \mathcal{T}_{t}-\frac{1+r_{f}}{1+\mathfrak{g}} b_{f, t-1}+\frac{1+r_{t-1}}{1+\mathfrak{g}} P_{t} b_{t-1} \\
& -P_{k, t} \sum_{\mathfrak{q}=j, n, x}\left(i_{\mathfrak{q}, t}+\mathbb{A C}_{\mathfrak{q}, t}\right)-\frac{\eta}{2}\left(b_{f, t}-\bar{b}_{f}\right)^{2}-P_{c, t} c_{2, t}-\mu_{t} z_{t-1},
\end{aligned}
$$

and, for each sector $\mathfrak{q}$ with $\mathfrak{q}=j, n, x$,

$$
(1+\mathfrak{g}) k_{\mathfrak{q}, t}=i_{\mathfrak{q}, t}+(1-\delta) k_{\mathfrak{q}, t-1}
$$

where $\beta=\beta_{o}(1+\mathfrak{g})^{1-1 / \tau}$ is the transformed discount factor, since $c_{2, t}$ is detrended consumption $\beta_{o}$ is the original discount factor; $\tau$ is the intertemporal elasticity of substitution; $b$ is the stock of domestic bonds; $i_{\mathfrak{q}}$ is gross investment in sector $\mathfrak{q}$, with $\mathfrak{q}=j, n, x ; \delta$ is the depreciation rate; $r_{f}$ is the exogenous real interest rate on foreign loans $b_{f} ; r$ is the real interest rate on domestic bonds; $\mu$ is the user fee charged for infrastructure services; $v$ and $\eta$ are positive constants; and $f_{\mathfrak{q}}, f_{h}$, and $f_{w}$ are tax rates on capital income (net of depreciation) in sector $\mathfrak{q}$, with $\mathfrak{q}=j, n, x$, land rents, and wage income in the formal sector.

In the budget constraint $(23), \mathbb{A C}_{\mathfrak{q}, t}=\frac{v}{2}\left(\frac{i_{\mathfrak{q}, t}}{k_{\mathfrak{q}, t-1}}-\delta-\mathfrak{g}\right)^{2} k_{\mathfrak{q}, t-1}$, capturing adjustment costs incurred in changing the capital stock in sector $\mathfrak{q}$, with $\mathfrak{q}=j, n, x .{ }^{16}$ The term $\frac{\eta}{2}\left(b_{f, t}-\bar{b}_{f}\right)^{2}$ measures portfolio adjustment costs associated with deviations of foreign loans from their steady-state level $\left(\bar{b}_{f}\right)$, and $P_{t}$ multiplies $b_{t}$ and $b_{t-1}$ because domestic bonds are indexed to the price level. ${ }^{17}$ Observe also that the trend growth rate appears in several places in (23) and (24), reflecting the fact that some variables are dated at $t$ and others at $t$ - 1 . Note that the convention for detrending the capital stocks differs from that for other variables. We define $k_{\mathfrak{q}, t-1} \equiv \frac{K_{\mathfrak{q}, t-1}}{(1+\mathfrak{g})^{t}}$ for $\mathfrak{q}=j, n, x$. Under this convention, $i_{\mathfrak{q}}=(\delta+\mathfrak{g}) k_{\mathfrak{q}}$ in the long run - as required for the capital stocks to grow at the trend growth rate $\mathfrak{g}$.

On an optimal path,

$$
c_{2, t}=c_{2, t+1}\left[\beta\left(\frac{1+r_{t}}{1+\mathfrak{g}}\right) \frac{P_{t+1}}{P_{t}}\left(\frac{P_{c, t}}{P_{c, t+1}}\right)\right]^{-\tau},
$$

for each sector $\mathfrak{q}$, with $\mathfrak{q}=j, n, x$,

$$
\frac{\left(\frac{r_{\mathfrak{q}, t+1}}{P_{k, t+1}}-\delta\right)\left(1-f_{\mathfrak{q}, t+1}\right)+1+\mathbb{D}_{\mathfrak{q}, t+1}\left(\frac{i_{\mathfrak{q}, t+1}}{k_{\mathfrak{q}, t}}+1-\delta\right)-\frac{1}{2} \mathbb{D}_{\mathfrak{q}, t+1}^{2}}{1+\mathbb{D}_{\mathfrak{q}, t}}=\left(1+r_{t}\right) \frac{P_{t+1}}{P_{t}}\left(\frac{P_{k, t}}{P_{k, t+1}}\right)
$$

\footnotetext{
${ }^{16}$ For simplicity, we assume that adjustment costs are zero when the capital stock grows at the trend growth rate. This ensures that adjustment costs are zero across steady states as in models that ignore trend growth.

${ }^{17}$ The nominal value of government bonds carried over from the previous period is $B_{t-1}$. This is marked-up through indexation to $\left(\mathbb{P}_{t} / \mathbb{P}_{t-1}\right) B_{t-1}$, where $\mathbb{P}=P_{x}\left[\kappa+(1-\kappa) P_{n}^{1-\varepsilon}\right]^{1 /(1-\varepsilon)}$. After dividing by $P_{x, t}$ (the traded good is the numeraire), we get $\left(\mathbb{P}_{t} / P_{x, t}\right)\left(B_{t-1} / \mathbb{P}_{t-1}\right)=P_{t} b_{t-1}$ in the private agent's budget constraint.
} 
where $\mathbb{D}_{\mathfrak{q}, t}=v\left(\frac{i_{\mathfrak{q}, t}}{k_{\mathfrak{q}, t-1}}-\delta-\mathfrak{g}\right)$, and

$$
\eta\left(b_{f, t}-\bar{b}_{f}\right)=1-\left(\frac{1+r_{f}}{1+r_{t}}\right) \frac{P_{t}}{P_{t+1}} .
$$

Each of these equations admits a straightforward intuitive interpretation. Equation (25) is a slightly irregular Euler equation in which the slope of the consumption path depends on the real interest rate adjusted for trend growth and changes in the VAT (which enter through $P_{c}$ ). The other equations represented by $(26)$ - one equation for each sector $\mathfrak{q}$, with $\mathfrak{q}=j, n, x$ - are arbitrage conditions. They require the return on capital, net of marginal adjustment costs, to equal the real interest rate. Similarly, equation (27) says that marginal transactions costs offset the interest differential between domestic bonds and foreign loans.

\section{Labor Market Features \\ C.1. The Effort Function}

Work effort of low-skill labor in the formal sector depends on their own wage, the wage in the informal sector, and the unemployment rate $\mathfrak{u}$ :

$$
e_{n, t}=g_{0}+g_{1} \ln \left(\frac{w_{n, t}}{P_{t}}\right)-g_{2} \ln \left(\frac{w_{j, t}}{P_{t}}\right)+g_{3} \mathfrak{u}_{t},
$$

where

$$
\mathfrak{u}_{t}=\frac{\bar{L}_{t}-L_{n, t}-L_{j, t}-L_{x, t}}{\bar{L}_{t}} .
$$

Naturally, workers exert more effort when they are paid a higher real wage and when low pay in the informal sector and high unemployment increase their gratitude for having a job.

The effort function in (28) may be derived either (i) in a more general version of the micro-theoretic model in Shapiro and Stiglitz (1984) where effort is a continuous variable and the utility loss from being fired for shirking is increasing in the unemployment rate and decreasing in the informal wage; ${ }^{18}$ or (ii) by appending a separable term in the utility function à la Collard and de la Croix (2000) and Danthine and Kurmann $(2004,2010)$ that captures the non-pecuniary loss from effort at the job. Neither method affects the other first-order conditions associated with the solution to the household's optimization problem.

\footnotetext{
${ }^{18}$ In the Shapiro-Stiglitz model where effort is either zero or one, the informal wage and the unemployment rate will enter the no-shirking condition.
} 


\section{C.2. Efficiency Wages, Unemployment, and Underemployment}

Firms in the formal sector recognize the connection between labor productivity and the real wage. Accordingly, they optimize over $w_{n}$ as well as $L_{n}$. The profit-maximizing choice for $w_{n}$ satisfies the Solow condition

$$
\frac{\partial e_{n, t}}{\partial\left(w_{n, t} / P_{t}\right)}\left(\frac{w_{n, t} / P_{t}}{e_{n, t}}\right)=1
$$

Equations (28) and (29) imply

$$
e_{n, t}=g_{1}
$$

Conveniently, effort is constant in general equilibrium. Without loss of generality, we set $e_{n}$ equal to unity at the initial equilibrium. The wage curve defined by (28) and (30) then reads

$$
\ln \left(\frac{w_{n, t}}{P_{t}}\right)=1-g_{0}+g_{2} \ln \left(\frac{w_{j, t}}{P_{t}}\right)-g_{3} \ln \mathfrak{u}_{t} .
$$

Efficiency wage considerations do not apply in the informal sector and agriculture, where selfemployment and family-run farms predominate. These two sectors form an integrated labor market with flexible wages. Total labor supply is inelastic at $\bar{L}_{x j}$, and job seekers move freely between the two sectors. Perfect, frictionless labor mobility does not guarantee, however, that (shadow) wages and MVPL are the same in sectors $x$ and $j$. Arbitrage in the $j-x$ labor market ensures only that

$$
\left(1-f_{w j}\right) w_{j, t}=\left(1-f_{w x}\right)\left(w_{x, t}+\sigma r_{h, t} \frac{H}{L_{x, t}}\right) \Longrightarrow \frac{1-f_{w j}}{1-f_{w x}} w_{j, t}=w_{x, t}\left(1+\frac{\sigma \chi}{1-\alpha_{x}-\theta_{x}-\chi}\right)
$$

with $0 \leq \sigma \leq 1$. When property rights are tenuous or non-existent in agriculture, $\sigma=1$ and labor receives its marginal value product $\left(w_{x}\right)$ plus a share of land rents. ${ }^{19}$ In this case, a reallocation of labor from agriculture to the informal sector increases aggregate labor productivity. Wage rigidity and open unemployment in the formal sector co-exists with multiple types of underemployment (in sector $j$ relative to sector $n$ and in sector $x$ relative to both sectors $j$ and $n$ ).

\section{C.3. Sectoral Labor Supply}

Two factors, one exogenous and the other endogenous, influence the sectoral supplies of low-skill labor:

$$
\bar{L}_{x j, t}=L_{x, t}+L_{j, t}=L_{x, 0}+L_{j, 0}-\Delta_{x j}\left(S_{t}-S_{0}\right)-\xi\left(L_{n, t}-L_{n, 0}\right) \quad \text { and } \quad \bar{L}_{t}=\bar{L}_{0}-\left(S_{t}-S_{0}\right)
$$

Public investment in upper-level education converts some low-skill workers into high-skill workers. The mechanism that determines $\Delta_{x j}$ and the impact on $\bar{L}_{x j}$ lies outside the purview of the model.

\footnotetext{
${ }^{19}$ Sharecropping introduces a similar wedge between $w_{x}$ and the MVPL for the tenant. In the simplest sharecropping model, $w_{x}$, as viewed by the tenant, equals $M V P L(1-\phi)$, where $\phi$ is the share of output paid to the landowner.
} 
New job openings in the formal sector also affect sectoral labor supply. The reflex assumption that the jobs go to the unemployed is generally incorrect. Workers in sector $x-j$ compete with the unemployed for prize jobs in the formal sector and may have an inside track to many of them. Hiring for wage jobs often occurs through informal channels. Employers put out the word that they are hiring and rely on referrals from existing employees to fill the jobs (Funkhouser, 1997a; Fields, 2011b; Fox 2015, Tansel et al., 2015). We do not attempt to model the role played by friend-family-kinship networks in the labor market. The first equation in (33) simply assumes that workers previously employed in sector $x-j$ obtain $\xi$ percent of newly created jobs in the formal sector.

\section{The Public Sector}

\section{D.1. Public Investment in Infrastructure}

"In the case of infrastructure, success will require breaking with the past by applying greater scrutiny of projects at the selection stage, integrity in procurement, and effective postcompletion management to ensure maintenance and efficient operation and continuing accountability to users." (Ndulu, 2006; our emphasis)

Casual observation and indirect empirical evidence suggest that all too often high returns on infrastructure capital do not translate into equally high returns on public investment either because of inadequate expenditure on maintenance or because a large fraction of public investment spending does not increase the stock of productive infrastructure (Hulten, 1996; Pritchett, 2000). The DIGLabor models allow for both types of inefficiency. Public investment $i_{z}$ increases the stock of physical infrastructure $\tilde{z}$ :

$$
(1+\mathfrak{g}) \tilde{z}_{t}=i_{z, t}+\left(1-\delta_{z, t}\right) \tilde{z}_{t-1}
$$

Some of the newly built infrastructure, however, may not be economically valuable, productive infrastructure:

$$
z_{t}=z_{0}+s\left(\tilde{z}_{t}-\tilde{z}_{0}\right)
$$

with $s \in[0,1]$ denoting the efficiency of public investment. ${ }^{20}$

Spending on maintenance $\mathfrak{m}$ extends the service life of infrastructure by reducing the depreciation rate:

$$
\delta_{z, t}=\delta_{o} e^{-\Lambda \mathfrak{m}_{t} / \tilde{z}_{t-1}}
$$

\footnotetext{
${ }^{20}$ The return on public investment is not necessarily lower in countries with a history of low efficiency of public investment. Low values of $s$ in equation (35) are counterbalanced by lower values of $z_{0}$ and a higher marginal product of infrastructure. In an apple-to-apple comparison of otherwise structurally identical countries, the return to investment may be higher in the low-efficiency country (Berg et al., 2019).
} 
where $\Lambda>1 / \delta_{o}$. Maintenance is underfunded relative to new investment when $\Lambda>1 / \delta_{z}$. In too many countries this condition holds with margin to spare.

\section{D.2. Public Investment in Human Capital}

Investment in human capital takes much longer to pay off than investment in infrastructure. The time lag is six years for investment in basic education $i_{b}$ and eight years for investment in upper-level education $i_{u}$, which implies:

$$
S_{b, t}=i_{b, t-6}+\left(1-\delta_{b}\right) S_{b, t-1} \quad \text { and } \quad S_{u, t}=i_{u . t-8}+\left(1-\delta_{u}\right) S_{u, t-1} .
$$

Fixed input-output coefficients connect increases in education capital to the supply of high-skill labor $S$ and the productivity of low-skill labor $e_{b}$ :

$$
S_{t}=S_{0}+\phi_{1}\left(S_{u, t-1}-S_{u, 0}\right) \quad \text { and } \quad e_{b, t}=1+\phi_{2}\left(S_{b, t-1}-S_{b, 0}\right) .
$$

\section{D.3. Fiscal Adjustment and the Public Sector Budget Constraint}

The government spends on debt service, investment in infrastructure $\mathbb{I}_{z}$ (including costs overrums), maintenance $\mathfrak{m}$, transfers $\mathcal{T}$, and total investment in education $i_{s} \equiv i_{b}+i_{u}$. It collects revenue from user fees for infrastructure services $\mu z$, the consumption VAT, and taxes on wages and profits for each sector $\mathfrak{q}$, with $\mathfrak{q}=j, n, x$. When revenues fall short of expenditures, the resulting deficit is financed through domestic, external commercial, or concessional borrowing ( $\Delta b, \Delta d_{c}, \Delta d$, respectively) viz.:

$$
\begin{aligned}
P_{t} \Delta b_{t}+\Delta d_{c, t}+\Delta d_{t}= & \frac{r_{d}-\mathfrak{g}}{1+\mathfrak{g}} d_{t-1}+\frac{r_{d c}-\mathfrak{g}}{1+\mathfrak{g}} d c_{t-1}+\frac{r_{t-1}-\mathfrak{g}}{1+\mathfrak{g}} P_{t} b_{t-1}+P_{z, t}\left(\mathbb{I}_{z, t}+\mathfrak{m}_{t}\right) \\
& +\mathcal{T}_{t}+P_{s, t} i_{s, t}-\mu_{t} z_{t-1}-h_{t}\left(P_{n, t} c_{n, t}+g_{j} P_{j, t} c_{j, t}+g_{x} c_{x, t}+g_{m} c_{m, t}\right) \\
& -\sum_{\mathfrak{q}=j, n, x}\left[f_{\mathfrak{q}, t}\left(r_{\mathfrak{q}, t}-\delta P_{k, t}\right) k_{\mathfrak{q}, t-1}+f_{w \mathfrak{q}, t} w_{\mathfrak{q}, t} L_{\mathfrak{q}, t}\right]-f_{w, t} w_{s, t} S_{t}-f_{h, t} r_{h, t} H,
\end{aligned}
$$

where $\Delta b_{t}=b_{t}-b_{t-1}, \Delta d_{c, t}=d c_{t}-d c_{t-1}, \Delta d_{t}=d_{t}-d_{t-1}$, and $r_{d}$ and $r_{d c}$ are the interest rates (in dollars) on concessional debt $d$ and commercial debt $d c$.

The term $P_{z, t} \mathbb{I}_{z, t}$, where $\mathbb{I}_{z, t}=\mathcal{H}_{t}\left(i_{z, t}-i_{z, 0}\right)+i_{z, 0}$, needs some explanation. Because skilled administrators are in scarce supply in LICs, ambitious public investment programs are often plagued by poor planning, weak oversight, and myriad coordination problems, all of which contribute to large cost overruns during the implementation phase. ${ }^{21}$ To capture this, we multiply new investment $\left(i_{z, t}-i_{z, 0}\right)$

\footnotetext{
${ }^{21}$ Development agencies report that cost overruns of 35 percent and more are common for new projects in Africa. The most important factor by far is inadequate competitive bidding for tendered contracts (Foster and Bricendo-Garmendia, 2010).
} 
by $\mathcal{H}_{t}$, where $\mathcal{H}_{t}=\left(1+\frac{i_{z, t}}{z_{t-1}}-\delta_{z}-\mathfrak{g}\right)^{\phi}$ and $\phi \geq 0$ determines the severity of the absorptive capacity constraint in the public sector. The constraint affects only implementation costs for new projects: at the initial steady state, $\mathcal{H}=1$, as $i_{z}=(\delta+\mathfrak{g}) / \tilde{z}$.

Policy makers eagerly accept all concessional loans proffered by official creditors. The borrowing and amortization schedule for these loans is fixed exogenously, implying that $\Delta d_{t}$ is given in the analysis. Thus, in any given year, the ex-ante financing gap $(\mathfrak{G} \mathfrak{a p})$ is

$$
\begin{aligned}
\mathfrak{G} \mathfrak{a p}_{t}= & \frac{1+r_{d, t}}{1+\mathfrak{g}} d_{t-1}-d_{t}+\frac{r_{d c}-\mathfrak{g}}{1+\mathfrak{g}} d c_{t-1}+\frac{r_{t-1}-\mathfrak{g}}{1+\mathfrak{g}} P_{t} b_{t-1}+P_{z, t}\left(\mathbb{I}_{z, t}+\mathfrak{m}_{t}\right) \\
& +\mathcal{T}_{0}+P_{s, t} i_{s, t}-\mu_{t} z_{t-1}-h_{0}\left(P_{n, t} c_{n, t}+g_{j} P_{j, t} c_{j, t}+g_{x} c_{x, t}+g_{m} c_{m, t}\right) \\
& -\sum_{\mathfrak{q}=j, n, x}\left[f_{\mathfrak{q}, t}\left(r_{\mathfrak{q}, t}-\delta P_{k, t}\right) k_{\mathfrak{q}, t-1}+f_{w \mathfrak{q}, t} w_{\mathfrak{q}, t} L_{\mathfrak{q}, t}\right]-f_{w, t} w_{s, t} S_{t}-f_{h, t} r_{h, t} H .
\end{aligned}
$$

That is, $\mathfrak{G} \mathfrak{a p}$ corresponds to expenditures (including interest rate payments on debt) less revenues and concessional borrowing, when transfers and taxes are kept at their initial levels $\mathcal{T}_{0}$ and $h_{0}$. In the short/medium run, part of this $\mathfrak{G} \mathfrak{a p}$ can be financed by domestic and/or external commercial borrowing, which are determined by

$$
P_{t} \Delta b_{t}=\left(1-\lambda_{d c}\right)\left[\mathfrak{G} \mathfrak{a} \mathfrak{p}_{t}+\mathcal{T}_{t}-\mathcal{T}_{0}-\left(h_{t}-h_{0}\right)\left(P_{n, t} c_{n, t}+g_{j} P_{j, t} c_{j, t}+g_{x} c_{x, t}+g_{m} c_{m, t}\right)\right]
$$

and

$$
\Delta d_{c, t}=\lambda_{d c}\left[\mathfrak{G} \mathfrak{a} \mathfrak{p}_{t}+\mathcal{T}_{t}-\mathcal{T}_{0}-\left(h_{t}-h_{0}\right)\left(P_{n, t} c_{n, t}+g_{j} P_{j, t} c_{j, t}+g_{x} c_{x, t}+g_{m} c_{m, t}\right)\right],
$$

where $\lambda_{d c} \in[0,1]$ splits the borrowing between domestic and external commercial borrowing.

Debt sustainability requires, however, that the VAT and transfers eventually adjust to cover the entire gap. We let policy makers divide the burden of adjustment (net windfall when $\mathfrak{G a p}<0$ ) between tax increases and spending cuts. The debt-stabilizing values for the VAT and transfers their long-run target values - are

$$
h_{t}^{\text {target }}=h_{0}+(1-\lambda) \frac{\mathfrak{G} \mathfrak{a} \mathfrak{p}_{t}}{P_{n, t} c_{n, t}+g_{j} P_{j, t} c_{j, t}+g_{x} c_{x, t}+g_{m} c_{m, t}} \quad \text { and } \quad \mathcal{T}_{t}^{\text {target }}=\mathcal{T}_{0}-\lambda \mathfrak{G} \mathfrak{a} \mathfrak{p}_{t}
$$

where policy makers' preferences fix $\lambda \in[0,1]$. These targets are paired with targets for the long-run levels of domestic and external commercial debt, $b^{\text {target }}$ and $d c^{\text {target }}$ as we explain next.

The paths of $h_{t}$ and $\mathcal{T}_{t}$ are governed by the following non-linear reaction functions:

$$
h_{t}=\operatorname{Min}\left\{h_{t}^{r}, h^{\text {cap }}\right\} \quad \text { and } \quad \mathcal{T}_{t}=\operatorname{Max}\left\{\mathcal{T}_{t}^{r}, \mathcal{T}^{\text {floor }}\right\}
$$

where

$$
h_{t}^{r}=h_{t-1}+\lambda_{1}\left(h_{t}^{\mathrm{target}}-h_{t-1}\right)+\lambda_{2} \frac{d c_{t-1}-d c^{\mathrm{target}}}{y_{t}}+\lambda_{5} \frac{b_{t-1}-b^{\mathrm{target}}}{y_{t}}
$$




$$
y_{t}=P_{n, t} q_{n, t}+P_{j, t} q_{j, t}+q_{x, t},
$$

and

$$
\mathcal{T}_{t}^{r}=\mathcal{T}_{t-1}+\lambda_{3}\left(\mathcal{T}_{t}^{\text {target }}-\mathcal{T}_{t-1}\right)-\lambda_{4}\left(d c_{t-1}-d c^{\text {target }}\right)-\lambda_{6}\left(b_{t-1}-b^{\text {target }}\right) .
$$

$h_{t}^{r}$ and are $\mathcal{T}_{t}^{r}$ linear rules that incorporate the targets for debt, the VAT rate and transfers, as well as the policy makers' preference parameters $\lambda_{1}-\lambda_{6}$.

The reaction functions in (44) that govern the paths of $h_{t}$ and $\mathcal{T}_{t}$ incorporate socio-political constraints on how much and how fast fiscal policy can change: $h^{\text {cap }}$ is the upper bound on the VAT and $\mathcal{T}^{\text {floor }}$ is the lower bound on transfers. ${ }^{22}$ Inside the bounds, the parameters $\lambda_{1}-\lambda_{6}$ determine whether policy adjustment is fast or slow. Under "slow" adjustment, $d c_{t}$ and/or $b_{t}$ may rise above its target level in the time it takes $h_{t}$ and $\mathcal{T}_{t}$ to reach $h_{t}^{\text {target }}$ and $\mathcal{T}_{t}^{\text {target }}$. When this happens, the transition path includes a phase in which $\mathcal{T}_{t}<\mathcal{T}_{t}^{\text {target }}$ and $h_{t}>h_{t}^{\text {target }}$ to generate the fiscal surpluses needed to pay down the debt.

The reaction functions also embody the core policy dilemma. Fiscal adjustment is painful, especially when administered suddenly in large doses. The government would prefer therefore to phase-in tax increases and expenditure cuts slowly. But if it moves too slowly, or if the bounds on $h_{t}$ and $\mathcal{T}_{t}$ constrain adjustment too much, interest payments will rise faster than revenue net of transfers, causing the debt to grow explosively. Large debt-financed increases in public investment are undeniably risky - the economy converges to a stationary equilibrium only if policy makers win the race against time.

\section{E. Market-Clearing Conditions and External Debt Accumulation}

Flexible wages and prices equate demand to supply in the market for skilled labor, the market for low-skill labor in sector $x-j$, and the markets for the two non-traded goods:

$S_{t}=S_{x, t}+S_{n, t}+S_{j, t}, \quad \bar{L}_{x j, t}=L_{x, t}+L_{n, t}, \quad q_{n, t}=c_{n, t}+a_{k n} \sum_{\mathfrak{q}=j, n, x}\left(i_{\mathfrak{q}, t}+\mathbb{A}_{\mathfrak{q}, t}\right)+a_{z n}\left(\mathbb{I}_{z, t}+\mathfrak{m}_{t}\right)+a_{s n} i_{s, t}$, and

$$
q_{j, t}=c_{j, t}+a_{k j} \sum_{\mathfrak{q}=j, n, x}\left(i_{\mathfrak{q}, t}+\mathbb{A C}_{\mathfrak{q}, t}\right)+a_{z j}\left(\mathbb{I}_{z, t}+\mathfrak{m}_{t}\right)+a_{s j} i_{s, t}
$$

where, to repeat, $\mathbb{A C}_{\mathfrak{q}, t}=\frac{v}{2}\left(\frac{i_{\mathfrak{q}, t}}{k_{\mathfrak{q}, t-1}}-\delta-\mathfrak{g}\right)^{2} k_{\mathfrak{q}, t-1}$ in sector $\mathfrak{q}$ and $\mathbb{I}_{z, t}=\mathcal{H}_{t}\left(i_{z, t}-i_{z, 0}\right)+i_{z, 0}$.

The model is closed by the accounting identity that growth in the country's net foreign debt equals

${ }^{22} \mathcal{T}^{\text {floor }}$ may be rising over time, as in the case where other cuts in non-investment expenditure do not offset growth in public sector wages.

(CInternational Monetary Fund. Not for Redistribution 
the current account deficit. Adding the public and private budget constraints produces

$$
\begin{aligned}
\Delta d_{t}+\Delta d c_{t}+\Delta b_{f, t}= & \frac{r_{d}-\mathfrak{g}}{1+\mathfrak{g}} d_{t-1}+\frac{r_{d c}-\mathfrak{g}}{1+\mathfrak{g}} d c_{t-1}+\frac{r_{f}-\mathfrak{g}}{1+\mathfrak{g}} b_{f, t-1}+\frac{\eta}{2}\left(b_{f, t}-\bar{b}_{f}\right)^{2}+P_{z, t}\left(\mathbb{I}_{z, t}+\mathfrak{m}_{t}\right) \\
& +P_{s, t} i_{s, t}+P_{t}\left(c_{1, t}+c_{2, t}\right)+P_{k, t} \sum_{\mathfrak{q}=j, n, x}\left(i_{\mathfrak{q}, t}+\mathbb{A C}_{\mathfrak{q}, t}\right)-P_{n, t} q_{n, t}-P_{j, t} q_{j, t}-q_{x, t},
\end{aligned}
$$

where $\Delta d_{t}=d_{t}-d_{t-1}, \Delta d c_{t}=d c_{t}-d c_{t-1}$, and $\Delta b_{f, t}=b_{f, t}-b_{f, t-1}$. This equation includes extra terms that reflect the impact of trend growth on real interest costs. The textbook identity emerges when $\mathfrak{g}=0$.

\section{Calibration of the Model and Solution Technique}

\section{A. Linking Some Parameters to Elasticities and Rates of Return}

To prepare the model for calibration, we need to (i) link the capital and foreign bond adjustment cost parameters $v$ and $\eta$, in $\mathbb{A C}_{\mathfrak{q}, t}=\frac{v}{2}\left(\frac{i_{\mathfrak{q}, t}}{k_{\mathfrak{q}, t-1}}-\delta-\mathfrak{g}\right)^{2} k_{\mathfrak{q}, t-1}$ and $\frac{\eta}{2}\left(b_{f, t}-\bar{b}_{f}\right)^{2}$, to observable elasticities; and to (ii) pin down the relationship between the returns on infrastructure and education capital, private sector output, and the parameters $\psi_{\mathfrak{q}}$ for each sector $\mathfrak{q}=j, n, x, \phi_{1}$ and $\phi_{2}$, which show up in equations (9), (10), (11) and (38). This is readily done. Starting with the first item, note that in each sector - drop for now the sub-index $\mathfrak{q}$ - the first-order condition for investment reads $\left[1+v\left(\frac{i_{t}}{k_{t-1}}-\delta-\mathfrak{g}\right)\right] \Lambda_{1, t} P_{k, t}=\Lambda_{2, t}$, where $\Lambda_{1}$ and $\Lambda_{2}$ are the multipliers associated with the budget constraint (23) and the law of motion for the capital stock (24). Since $\frac{\Lambda_{2}}{\Lambda_{1}}$ is the shadow price of $k$ measured in dollars, $\frac{\Lambda_{2}}{\Lambda_{1}} P_{k}$ is effectively Tobin's $Q$, the ratio of the demand price to the supply price of capital. Let $\Omega \equiv \frac{\hat{I}}{\hat{q}}$ denote the $Q$-elasticity of investment spending. Evaluated at a stationary equilibrium, we then have $v(\delta+\mathfrak{g}) \Omega=1$, which, for given $\delta$, $\mathfrak{g}$, and $\Omega$, helps pin down $v$.

We employ a similar strategy to link the portfolio adjustment cost parameter to an elasticity that reflects the degree of substitutability between domestic bonds and foreign loans. Write equation (27) as $\eta \Gamma=\frac{1}{Y}$, where $Y$ is annual GDP and $\Gamma \equiv\left(\frac{b_{f, t}-\bar{b}_{f}}{Y}\right) \frac{1}{I R D}$ is the ratio of capital flows, measured as a percentage of annual GDP, to the interest rate differential $I R D \equiv 1-\left(\frac{1+r_{f}}{1+r_{t}}\right) \frac{P_{t}}{P_{t+1}}$. Since $\eta$ is not observable or unit free, we calibrate to $\Gamma$.

The only inputs needed to calculate the return on infrastructure are the purchase price $P_{z}$ and the shadow rental $r_{z}$. The latter is simply the marginal value product of infrastructure at constant prices. From (9) - (11),

$$
r_{z}=\frac{\psi_{x} q_{x}+P_{n} \psi_{n} q_{n}+P_{j} \psi_{j} q_{j}}{z}
$$

The net return — the return that measures the contribution to Net National Product — is

$$
R_{z}=\frac{r_{z}}{P_{z}}-\delta_{z}-\frac{\mathfrak{m}}{z}=\frac{\psi_{x} q_{x}+\psi_{n} P_{n} q_{n}+P_{j} \psi_{j} q_{j}}{P_{z} z}-\delta_{z}-\frac{\mathfrak{m}}{z},
$$


assuming maintenance spending increases with $z$ to keep the depreciation rate constant. ${ }^{23} \delta_{z}$ is set directly, while $q_{n}, q_{x}, q_{j}, z$, and $P_{z}$ are derived from the values of other variables. $\left(P_{n}=P_{j}=1\right.$ by choice of units.) This leaves $R_{z}, \psi_{x}, \psi_{j}$, and $\psi_{n}$ as unknowns in equation (45). We assign values to $R_{z}, \frac{\psi_{j}}{\psi_{x}}$, and $\frac{\psi_{n}}{\psi_{x}}$ and instruct the computer to solve (45) for $\psi_{x}$.

Calculating the returns to education capital is a more complicated business. Evaluated at the initial steady state, the shadow rentals are

$r_{b}=\left(\lambda_{x} q_{x}+\lambda_{n} P_{n} q_{n}+\lambda_{j} P_{j} q_{j}\right) \phi_{2} \quad$ and $\quad r_{u}=\left\{w_{s}\left(1-\Delta_{x j}\right)+\left[w_{s}-w_{j}\left(1-\frac{d L_{x}}{d \bar{L}_{x j}}\right)-w_{x} \frac{d L_{x}}{d \bar{L}_{x j}}\right] \Delta_{x j}\right\} \phi_{1}$,

where we have used the facts $\frac{d e_{b}}{d S_{b}}=\phi_{2}, \frac{d S}{d S_{u}}=\phi_{1}$, and $\frac{d L_{j}}{d \bar{L}_{x j}}=1-\frac{d L_{x}}{d \bar{L}_{x j}}$ and the following definitions $\lambda_{x} \equiv 1-\alpha_{x}-\theta_{x}-\chi, \lambda_{n} \equiv 1-\alpha_{n}-\theta_{n}$, and $\lambda_{j} \equiv 1-\alpha_{j}-\theta_{j}$. Hence

$$
R_{b}=\frac{r_{b}}{P_{s}}-\delta_{b}=\left(\lambda_{x} q_{x}+\lambda_{n} P_{n} q_{n}+\lambda_{j} P_{j} q_{j}\right) \frac{\phi_{2}}{P_{s}}-\delta_{b}
$$

and

$$
R_{u}=\frac{r_{u}}{P_{s}}-\delta_{u}=\left\{w_{s}\left(1-\Delta_{x j}\right)+\left[w_{s}-w_{j}\left(1-\frac{d L_{x}}{d \bar{L}_{x j}}\right)-w_{x} \frac{d L_{x}}{d \bar{L}_{x j}}\right] \Delta_{x j}\right\} \frac{\phi_{1}}{P_{s}}-\delta_{u} .
$$

Analagous to (45), equation (46) neatly ties $\phi_{2}$ to the value assigned to $R_{b}$. In (47), however, the return depends on the messy general equilibrium solution for $\frac{d L_{x}}{d \bar{L}_{x j}}$. We approximate $\frac{d L_{x}}{d \bar{L}_{x j}}$ by the initial employment share $\frac{L_{x}}{L_{x}+L_{j}}$ and work with

$$
R_{u}=\left[w_{s}\left(1-\Delta_{x j}\right)+\left(w_{s}-w_{x j}\right) \Delta_{x j}\right] \frac{\phi_{1}}{P_{s}}-\delta_{u}
$$

where

$$
w_{x j} \equiv \frac{L_{x}}{L_{x}+L_{j}} w_{x}+\frac{L_{j}}{L_{x}+L_{j}} w_{j}
$$

Two other points merit comment. First, $R_{z}$ and $R_{b}$ are partial equilibrium returns that do not take into account the impact of increases in infrastructure and higher productivity of low-skill labor on unemployment and underemployment. The general equilibrium returns, which incorporate the effects of $z, e_{b}$, and induced increases in the private capital stock on labor demand, are much higher than $R_{z}$ and $R_{b}$. The rationale for calibrating to partial instead of general equilibrium returns is that, among other advantages (e.g., simplicity), it facilitates communication with the data: $R_{z}$ and $R_{b}$ closely align with empirical estimates of returns to infrastructure and education.

The interpretation of $R_{u}$ is slightly different. Obviously, calculation of the return in (47) requires information on how low-skill employment changes in each sector. $R_{u}$ is still a partial equilibrium measure, however. It captures only the direct gain from converting low-skill labor, drawn in a particular mix from sectors $n, j$, and $x$, into high-skill labor. The general equilibrium gains from increases in

\footnotetext{
${ }^{23}$ Equation (45) assumes $\tilde{z}=z$ and $s_{0}=s=1$.
} 
the supply of skilled labor and crowding-in of private capital further reducing unemployment and underemployment by raising the productivity of low-skill labor are missing.

Second, unlike $R_{z}, R_{u}$ and $R_{b}$ are not (partial equilibrium) internal rates of return. Because of the long time lag that separates investment from the start date of returns, the internal rate of return $(I R R)$ is lower than $R_{u}$ or $R_{b}$. To get a rough sense of how much lower, switch for facility to continuous time and calculate

$$
V=\int_{0}^{\infty}\left[Y\left(S_{u}\right)-P_{s} i_{u}\right] e^{-\rho t} d t \quad \text { with } \quad \dot{S}_{u}=i_{u}-\delta_{u} S_{u}
$$

when it takes $t_{1}$ years for a jump in $i_{u}$ from $i_{u 0}$ to $i_{u 1}$ to increase $S_{u}$. The path for $S_{u}$ is

$$
S_{u}=\left\{\begin{array}{l}
S_{u 0}, \quad 0 \leq t \leq t_{1}, \\
S_{u 0}+\left(S_{u 1}-S_{u 0}\right)\left[1-e^{-\delta_{u}\left(t-t_{1}\right)}\right], \quad t \geq t_{1},
\end{array}\right.
$$

where $S_{u 0}=\frac{i_{u 0}}{\delta_{u}}$ and $S_{u 1}=\frac{i_{u 1}}{\delta_{u}}$. The $I R R$ is the value of $\rho$ for which

$$
V\left(i_{u 1}\right)-V\left(i_{u 0}\right)=0 \quad \Longrightarrow \quad \int_{t_{1}}^{\infty}\left(R_{u}+\delta_{u}\right)\left(S_{u}-S_{u 0}\right) e^{-\rho t} d t=\int_{0}^{\infty}\left(i_{u 0}-i_{u 1}\right) e^{-\rho t} d t
$$

Substituting for $S_{u}-S_{u 0}$ from (48) leads to

$$
\frac{R_{u}+\delta_{u}}{\rho+\delta_{u}} e^{-\rho t_{1}}=1
$$

The time lag takes a heavy toll. As $t_{1}$ rises, for $R_{u}$ between 20 and 30 percent and a depreciation rate $\delta_{u}$ of 5 percent, the $I R R$ decreases rapidly, dropping from 20 - 30 percent at $t_{1}=0$ to $9.3-12$ percent at $t_{1}=6$ and to $7.2-9.1$ percent at $t_{1}=10$.

\section{B. Base Case Calibration}

Calibration of the model requires data on cost shares, elasticities of substitution, consumption shares, depreciation rates, tax rates, debt stocks, and the returns on infrastructure and education capital at the benchmark equilibrium. Once values are set for these parameters, all other variables that enter the model can be tied down by budget constraints, the first-order conditions associated with the solution to the private agents' optimization problems, and various adding-up constraints.

The values in Table 3 are based on a mixture of data, empirical estimates, and guesstimates. We discuss below the rationale for the value assigned to each parameter and the problems that arose in calibrating certain parts of the model: 
- Consumption shares of goods $n, m, j$, and $x\left(\gamma_{n}, \gamma_{m}, \gamma_{j}\right.$, and $\left.\gamma_{x}\right)$. The consumption shares for the formal good, the informal good, the imported consumer good, and the agricultural good are 40 percent, 20 percent, 10 percent, and 30 percent, respectively. These shares and the values assigned to other parameters imply GDP shares of 31.8 percent, 25.5 percent, and 42.7 percent for sectors $n, j$, and $x$.

- Intertemporal elasticity of substitution $(\tau)$. Most estimates of $\tau$ for LDCs lie between 0.15 and 0.75 (Agenor and Montiel, 2015). The value in the base case, 0.40, is slightly higher than the average estimate for LICs in Ogaki et al. (1996).

- Elasticity of substitution in consumption between good $x$ and other goods $\left(\varepsilon_{1}\right)$. We fix $\varepsilon_{1}$ at 0.50 as estimates of compensated elasticities of demand tend to be small at high levels of aggregation, especially when food claims a large share of total consumption. ${ }^{24}$

- Elasticity of substitution in consumption between the composite formal good - i.e., $c_{n m}$ - and the informal good $\left(\varepsilon_{2}\right)$. Estimates of demand systems do not distinguish between goods produced by formal and informal firms. The right value for $\varepsilon_{2}$ is a judgment call therefore that depends on whether firms in the formal and informal sectors sell in similar or distinct product markets. Variation across countries in the sectoral overlap between formal and informal firms suggests that both high and low values of $\varepsilon_{2}$ are defensible. In LICs, informal firms cluster in services and commerce while formal firms dominate in manufacturing. Since DIG-Labor 1 is framed with LICs in mind, $\varepsilon_{2}=0.5$ in the base case.

- Elasticity of substitution between imported consumer goods and the formal good $\left(\varepsilon_{3}\right)$. The law of one price does not hold for manufactured goods, which, unlike primary products, are highly heterogeneous. The characterization of the formal sector as tradable or non-tradable depends therefore on the value assigned to $\varepsilon_{3}$. Lacking a strong prior for this parameter, we carry out runs for both $\varepsilon_{3}=0.5$ and $\varepsilon_{3}=5$.

- Wages in the formal and informal sectors $\left(w_{s}, w_{n}\right.$, and $\left.w_{j}\right)$. The formal sector wage premium for low-skill labor is highly country specific. For the base case, we chose the mid-range value 67 percent $\left(w_{n}=1\right.$ and $\left.w_{j}=.60\right)$. The wage for skilled labor $\left(w_{s}=3\right)$ agrees with data on wages for workers with high vs. low levels of education in Latin America (Joumard and Velez, 2013) and with empirical estimates that each additional year of upper-level education raises earnings $11-13$ percent. $^{25}$

\footnotetext{
${ }^{24}$ See Lluch et al. (1977, chapter 3), Deaton and Muellbauer (1980, p.71), Blundell (1988, p.35), and Blundell et al. (1993, Table 3b).

${ }^{25}$ See Peet et al. (2015) for recent, comparable estimates of the increase in earnings for each additional year of postprimary education in Africa. The simple average for secondary and tertiary education is 11 percent in Uganda and Malawi, 12.7 percent in Tanzania, 12 percent in Niger, and 12.8 percent in Ethiopia. the average for the group is 11.9 percent. If high-skill workers have 10 more years of education than low-skill workers, $w_{s}=(1.119)^{10}=3.07$.
} 
- Factor shares in the formal sector $\left(\alpha_{n}\right.$ and $\left.\theta_{n}\right)$. Data on factor shares may be found in World Bank Enterprise Surveys and in social accounting matrices assembled by GTAP (Global Trade Analysis Project) and IFPRI (International Food Policy Research Institute). These sources suggest a capital share of 40-60 percent in LICs. The data in Thurlow et al. (2004) and Perrault et al. (2010) suggest similar numbers. Accordingly, we set $\alpha_{n}=0.50$. There is no hard data on factor shares by skill or education level. We set the cost share for high-skill labor to be consistent with data on the share of high-education (secondary+) workers in the formal sector. The values assigned to $\theta_{n}(0.30)$ and the wage rates $w_{s}$ and $w_{n}$ give an employment share of 33.3 percent for high-skill labor. By way of comparison, the share is 35.6 percent in Côte d'Ivoire (Gunther and Launov, 2012) and 32.9 percent in Egypt (Harati, 2013).

- Factor shares in the informal sector $\left(\alpha_{j}\right.$ and $\left.\theta_{j}\right)$. Good, sensible data are not readily available for factor shares in the informal sector. We chose cost shares to match data on the share of high-education workers in the informal sector and the share of the informal sector in total non-agricultural employment. High-education workers account for 6.2 percent of informal sector employment in Côte d'Ivoire (Gunther and Launov, 2012) and 7 percent in Egypt (Harati, 2013). The informal sector share in non-agricultural employment equals 75 percent in Sub-Saharan Africa and 70 percent in South Asia and Southeast Asia (OECD, 2009). For the base case values $\alpha_{j}=0.20$ and $\theta_{j}=0.20$ in DIG-Labor 1 , the high-skill employment share in the informal sector is 6.3 percent and the sector's share in non-agricultural employment is 74.1 percent.

- Factor shares in agriculture $\left(\chi, \alpha_{x}\right.$, and $\left.\theta_{x}\right)$. It is no secret that there are problems with the data for labor, land, and capital costs in smallholder agriculture. Given the limitations of the data, our preference is to consult a variety of sources and hope that a rough consensus emerges about the likely values for factor shares. This hope is partly satisfied: Restuccia and SantaeulaliaLlopis (2017) estimate the land share from survey data for Malawi to be 36 percent; in the GTAP database, the cost share for land in LDCs ranges from 12 percent to 51 percent, while Fuglie (2010) cites studies that place the cost share between 22 percent and 29 percent in India, Indonesia, China, Mexico, and Sub-Saharan Africa; the common 50-50 split in sharecropping contracts (Otsuka, 2007) suggests a cost share of 50 percent for labor and 30-35 percent for land (the landowner usually provides equipment and structures in addition to land). In keeping with these numbers and the fact that smallholder agriculture in LICs is highly intensive in low-skill labor, we fixed the cost shares for land, capital, and high-skill labor at 30 percent, 20 percent, and 5 percent, respectively. ${ }^{26}$ For these shares and the factor shares assigned in sectors $j$ and $n$, the shadow wage in agriculture is 40 percent less than the wage in the informal sector

\footnotetext{
${ }^{26}$ These are conventional values. Gottlieb and Grobovsek (2019) set the cost for land at 33 percent in Ethiopia. Chen (2017) chooses 27 percent - a "conservative value" — for Mali and observes that there is a general consensus the cost share of labor is close to 50 percent.
} 
$\left(w_{x}=0.36\right.$ vs. $\left.w_{j}=0.60\right)$ and agriculture's share in total employment equals 59.5 percent.

- Depreciation rates $\left(\delta, \delta_{z}, \delta_{u}\right.$, and $\left.\delta_{b}\right)$. Our choice of 5 percent is in line with estimated depreciation rates for private capital in developed countries (Musgrave, 1992; Nadiri and Prucha, 1996) and for various types of infrastructure in LDCs (Pereira and Ferreira, 2008; Ianchovichina et al., $2012)^{27}$

- Real interest rate on concessional + semi-concessional loans $\left(r_{d}\right)$. The IMF's Debt Sustainability Analyses show an interest rate close to 2 percent on concessional loans taken out by LICs. Assuming 2 percent inflation in world prices of traded goods, the corresponding real rate (in dollars) is zero. For semi-concessional loans from non-Paris Club creditors, the OPEC Fund, etc., we assume a real interest rate of 3 percent. The weighted average rate, $r_{d}$, equals 1.3 percent.

- Real interest rate on external commercial loans $\left(r_{d c}\right)$. In recent years, Ghana, Kenya, Senegal, Tanzania, Nigeria, Rwanda, and Angola have floated Eurobonds paying interest rates of 6-9.7 percent. The average real rate in dollars is approximately 6 percent.

- Trend growth rate $(\mathfrak{g})$. The average growth rate in per capita income for 2002-2017 was 1.2 percent in fragile LICs and 3.5 percent in non-fragile LICs (IMF, 2018). We use the simple average of the two growth rates $(\mathfrak{g}=.023)$.

- Ratio of user fees to recurrent costs per unit of infrastructure $(f)$. The user fee for infrastructure services is a fixed multiple/fraction $f$ of recurrent costs, thus $\mu=f\left(\delta_{z}+\mathfrak{m}\right) P_{z, 0}$. Fuel taxes (earmarked for road maintenance and construction), electricity tariffs, and user charges for water and sanitation are low but not trivial in LICs. On average, user fees recoup 50 percent of recurrent costs in Sub-Saharan Africa (Briceno-Garmendia et al., 2008). There is tremendous variation, however, across time periods and countries.

- Consumption VAT rates $\left(h, g_{x}, g_{j}\right.$, and $\left.g_{m}\right)$. The consumption VAT in the model proxies for all indirect taxes (VAT, sales and excise taxes, etc.). Our rate of 20 percent is representative of the aggregate indirect tax rate in LICs. Exemptions for foodstuffs and limited enforcement of the VAT outside the formal sector suggest that $g_{x}$ and $g_{j}$ are far below 0.5. Based on this and World Bank data showing C-efficiency ratios of $0.3-0.7$ in SSA, we set $g_{j}$ at 0.3 and $g_{x}$ at $0.1 .^{28}$ Imports pay the same rate as the formal good in the base case $\left(g_{m}=1\right)$. When the government discourages consumer imports with a tariff, $g_{m}>1$.

\footnotetext{
${ }^{27}$ The Fiscal Affairs Department of the IMF also uses 5 percent in its perpetual inventory calculations of public sector capital stocks.

${ }^{28}$ The C-efficiency ratio is the ratio of actual revenue raised from the VAT to revenue that would be raised with all consumption subject to the tax. In the base case, the C-efficiency ratio is 0.56.
} 
- Taxes on wages, profits, and land rents $\left(f_{n}, f_{j}, f_{x}, f_{h}, f_{w}, f_{w x}\right.$, and $\left.f_{w j}\right)$. La Porta and Shleifer (2008) report that firms in the formal sector evade 30 percent of their tax liability. The number increases to 75 percent for the informal sector. Taking these numbers as a guide, we fixed $f_{n}$ at 0.15 and $f_{j}$ at 0.03 , and $f_{x}$ at 0.02 . Taxes on wage income are significant only in the formal sector. The base case assumes tax rates of 12 percent in the formal sector and 1 percent in the informal sector and smallholder agriculture. ${ }^{29}$ Total revenue from income taxes is 5.1 percent of GDP, the number for LICs in 2015 (Akitoby et al., 2018). Combined revenue from income taxes, the VAT, and user fees equals 16.4 percent of GDP, the average for LICs in 2015 (Akitoby et al., 2018).

- Efficiency of public investment $(s)$ and the absorptive capacity constraint $(\phi)$. The base case assumes that public investment is efficient and that scaling up does not strain absorptive capacity $(\phi=0) \cdot{ }^{30}$

- Return on infrastructure $\left(R_{z}\right)$ and the elasticity parameters $\left(\psi_{i}\right)$. Estimates of the return on infrastructure are all over the map, but the weight of the evidence in both micro and macro studies points to a high average return. The median rate of return on World Bank projects circa 2001 was 20 percent in Sub-Saharan Africa and 15-29 percent for various sub-categories of infrastructure investment. In the Bank's comprehensive study of infrastructure in Africa, estimated returns for electricity, irrigation, and roads range from 17 percent to 24 percent (Briceno-Garmendia and Foster, 2010, chapter 2); ${ }^{31}$ in developing Asia, the average returns for roads, electricity transmission and distribution, and power generation are 23 percent, 20 percent, and 33 percent, respectively (Asian Development Bank, 2017). Similarly, the macro-based estimates in Dalgaard and Hansen (2005) cluster between 15 percent and 30 percent for a wide array of different estimators. Hulten et al. (2006) and Escribano et al. (2008), supply additional evidence of high returns. Some growth regressions suggest low or insignificant returns, but these are dominated by studies that use cumulative public investment instead of physical indicators to measure the stock of infrastructure. All of this adds up to a presumption that high returns are the norm. Our low-, average-, and high-return scenarios assume therefore initial returns of 10 percent, 20 percent, and 30 percent, respectively. ${ }^{32}$ The associated values for $\psi$, the elasticity of GDP with respect to infrastructure (when $\psi_{n}=\psi_{j}=\psi_{x}=\psi$ ) are $0.140,0.222$, and $0.304 .{ }^{33}$ To economize

\footnotetext{
${ }^{29}$ In the case of smallholder agriculture, the tax rate on (implicit) land rents is the same as the tax on wage income $\left(f_{h}=f_{w x}=0.01\right)$.

${ }^{30}$ The estimates in Presbitero (2016) indicate that rapid scaling-up of investment adversely effects project outcomes. The effect is quite small, however.

${ }^{31}$ The estimated return for road maintenance is 139 percent.

${ }^{32}$ Thirty percent may raise some eyebrows, but it is not as big as some of the numbers thrown around in the literature.

${ }^{33}$ The values in the average-return and high-return scenarios are close to the average estimate forless-developed countries (0.22) and the estimate for Africa (0.32) in Ivanchovichina et al. (2013), the estimate for Chile (0.219) in AlbalaBertrand and Mamazatkis (2001), and the range of estimates for South Asia (0.21 - 0.34) in Sahoo and Dash (2012), while the value in the low-return scenario is slightly lower than the range of estimates (0.15-0.18) in Calderon and Serven
} 
on space, we present results only for the average-return scenario.

- The discount rate $(\beta)$, the real interest rate $(r)$ on domestic bonds, and the real return on private capital. Across steady states, the real interest rate on domestic debt and the real return on private capital equal $(1+\mathfrak{g}) / \beta-1$. We choose $\beta$ jointly with $\mathfrak{g}$ so that the domestic real interest rate is 10 percent at the initial equilibrium. This is consistent with the data for Sub-Saharan Africa in Fedelino and Kudina (2003); with the estimated return on private capital in Isham and Kaufmann (1999), Dalgaard and Hansen (2005), and Marshall (2012); with the stylized fact that domestic debt in LICs and MICs is usually much more expensive than external commercial debt; and with the range of real loan rates in LDCs (generally 7 - 15 percent) reported in World Development Indicators.

- Real interest rate on foreign debt held by the private sector $\left(r_{f}\right)$. Equation (27) implies that $r_{f}=r$ across steady states. Hence $r_{f}=0.10$, a value that incorporates a substantial risk premium.

- Interest elasticity of private capital flows $(\Gamma)$. Empirical evidence on the likely value of $\Gamma$ is limited and indirect. The value in the base case, unity, implies that a one percentage point increase in the domestic interest rate induces capital inflows equal to one percent of annual GDP. This intermediate degree of capital mobility is consistent with the estimate of $\Gamma$ for EMEs in Chang et al. (2013), with the estimated response of capital flows to the interest rate differential in De Gregorio et al. (2000), with the finding that the offset coefficient for capital flows is far below unity $(0.15-0.60)$ in LDCs and transition economies (Ljubaj et al., 2010), and with abundant casual evidence that capital flows in LICs are not elastic enough to prevent large fluctuations in domestic bond rates. ${ }^{34}$

- Initial ratios of maintenance spending and investment in infrastructure to $G D P\left(P_{z} \mathfrak{m} / G D P\right.$ and $\left.P_{z} i_{z} / G D P\right)$. Outlays on depreciation and net investment associated with trend growth sum to 6 percent of GDP, the average for LICs in Sub-Saharan Africa. Proper maintenance of roads, railroads, and the electrical grid requires annual expenditure equal to two percent of the capital stock (Yepes, 2010). This works out to 1.64 percent of GDP at the initial equilibrium.

- Initial ratios of investment in education capital to GDP $\left(P_{s} i_{b} / G D P\right.$ and $\left.P_{s} i_{u} / G D P\right)$. Government expenditure on education is $3-7$ percent in the great majority of LDCs. Data on expenditure by level of education are not generally available, but post-secondary education claims 22 - 28 percent of total spending in Mexico, Argentina, Colombia, Costa Rica, and Turkey. ${ }^{35}$ We set

(2003) and slightly higher than the range (0.07-0.10) in Calderon et al. (2015).

${ }^{34}$ It should also be noted here that in $20-25$ percent of LICs the elasticity of non-FDI private capital flows is comparable to that for emerging markets (Araujo et al., 2015).

${ }^{35}$ The numbers cited here and for total government spending on education are from OECD Education Statistics (OECD 
investment in basic and upper-level education at 2.8 percent and 1.2 percent percent of GDP, respectively. Investment in upper-level education is 30 percent of total education spending higher than the 22-28 percent figure cited above because it includes spending on secondary education.

- Domestic debt (b). Domestic debt ratios have risen substantially in last ten years. The value in the base case, 15 percent of GDP, equals the median value in LICs in 2016 (IMF, 2018).

- Private and public external debt $\left(b_{f}, d\right.$, and $\left.d c\right)$. Concessional + semi-concessional loans and external commercial debt are respectively 32 percent and 6 percent of GDP, the values for LICs in 2016 (IMF, 2018). ${ }^{36}$ Since little is known about the likely value of private foreign debt (or assets) in LICs, we chose $\bar{b}_{f}=0$ for the base case.

- Q-elasticity of investment spending $(\Omega)$. There are only a couple of reliable estimates of this elasticity for LDCs. The estimates for Egypt in Shafik (1992) and for Korea in Kong (2002) and Kim et al. (2015) are $2.11-2.56,3.1$, and $2.08-2.36$, respectively. The assigned value $\Omega=2.5$ is consistent with these estimates and with estimates for developed countries that clean noisy data from $Q$ and relate investment to the fundamentals. ${ }^{37}$ The results do not change substantively when $\Omega$ equals 0.5 or 10 .

- Return on maintenance relative to new investment in infrastructure $\left(R_{\mathfrak{m} z}\right)$. In the base case $R_{\mathfrak{m} z}=1$ on the optimistic assumption that maintenance spending suffices to secure a normal service life for the infrastructure stock.

- Share of new high-skill workers drawn from the pool of low-skill workers in sector $x-j\left(\Delta_{x j}\right)$ and the fraction of newly created/vacant formal sector jobs filled by workers from sector $x-j(\xi)$. Unfortunately, the values assigned to $\Delta_{x j}(0.80)$ and $\xi(0.50)$ are pure guesses. Data do not exist to quantify either of these parameters, although informed observers maintain that $\xi$ is large. ${ }^{38,39}$

Database), the UNESCO Institute of Statistics, and the Digest of Education Statistics (National Center for Education Statistics).

${ }^{36}$ The initial values of $d$ and $d c$ affect the initial value of transfers but little else. There is virtually no impact on the solution path.

${ }^{37}$ Numerous estimates place the $Q$-elasticity between 0.3 and 1.5 in developed countries. there are many reasons to believe, however, that most empirical estimates of $\Omega$ are biased downward. Besides the bias from noise in stock prices that proxy for the demand price of capital, there is aggregation bias, bias from imperfect competition in product markets, bias from the fact that even non-noisy stocks prices track average $Q$ but not marginal $Q$ (the two are equal only under stringent conditions unlikely to hold), and bias from endogeneity of $Q$. See Shapiro (1986), Schaller (1990), Hayashi and Inoue (1991), and Chirinko (1993). Eberly et al. (2008) quantify the bias created by noisy data for $Q$. It is considerable. When variation in $Q$ reflect only variation in the fundamentals, the estimated $Q$-elasticities in the Generalized Hayashi model with and without regime-switching are 9.3 and 2.56. Re-estimating the model with noisy data for $Q$ reduces the elasticities to $0.16-0.74$ and $0.36-1.16$.

${ }^{38}$ Although there is an urban bias in the supply of secondary + tertiary education, it seems unlikely that $1-\Delta_{x j}$ will differ significantly from the formal sector share in the total supply of low-skill labor - i.e., $\left(L_{n}+L_{u}\right) /\left(L_{n}+L_{u}+L_{x}+L_{j}\right)$. In the base case, this equals 11.1 percent.

${ }^{39}$ Users should note that their guess for $\Delta_{x j}$ depends in part on their guess for $\xi$. Suppose, for example, that investment 
- Unemployment rate $(\mathfrak{u}) . \mathfrak{u}$ is the national unemployment rate in the low-skill labor market. This is the conceptually correct definition of the unemployment rate, given that the informal sector and agriculture form an integrated labor market. The equivalent urban unemployment rate, calculated using the official government definition, is 12.9 percent. ${ }^{40}$ Fox (2015) reports that the range is $11-15$ percent in most of Sub-Saharan Africa.

- Elasticity of the real wage in the formal sector with respect to the unemployment rate $\left(g_{3}\right)$ and the real wage in the informal sector $\left(g_{2}\right)$. Estimates of wage curves in the formal sector place $g_{3}$ between 0.05 and 0.15 (see Appendix B). We chose the midpoint for the base case. The right value for $g_{3}$ depends on the fraction of low-skill formal sector employees who, if they lose their job, are willing to work in the informal sector. We suspect this is close to $\xi$ (the fraction of newly created/vacant formal sector jobs filled by workers from sector $x$ - $j$ ). Ergo $g_{2}=0.5$.

- Cost shares of non-traded inputs in the production of capital goods $\left(\alpha_{i j}\right.$, and $\alpha_{i n}$, for $\left.i=s, z, k\right)$. Data on the ratio of imported machinery and equipment to aggregate investment indicate that $\alpha_{k j}+\alpha_{k n}$ is around 0.50 in Sub-Saharan Africa. One-half is also the guesstimate used by the IMF (2007) in its analysis of scaling up public investment in Nigeria. Since informal firms dominate the construction sector, we set $\alpha_{k n}=\alpha_{z n}=0.15$ and $\alpha_{k j}=\alpha_{z j}=0.35$. Education capital is much less import intensive; our educated guesses are $\alpha_{s n}=0.20$ and $\alpha_{s j}=0.60$.

- Returns to education $\left(R_{u}\right.$ and $\left.R_{b}\right)$. Psacharopoulos and Patrinos (2004) compile estimates of private and social returns to education in 84 countries. In LICs, the average social return (i.e., the return that includes all private and public costs) is 21.3 percent for primary education, 15.7 percent for secondary education, and 11.2 percent for tertiary education. But the studies that underlie these average returns differ widely in their data sources, models, estimation methods, assumptions about opportunity costs, and overall quality. They also tend to rely on non-representative surveys that oversample urban areas and large firms within the formal sector. ${ }^{41}$ More recent studies by Barouni and Broecke (2014), Montenegro and Patrinos (2014), and Peet et al. (2015) use a consistent methodology and comparable, representative data. All three studies suggest that the estimated private returns collected in Psacharopoulos and Patrinos (2004) are too high, especially for primary education. ${ }^{42}$ Assuming comparisons of social returns would yield similar results, we chose an internal rate of return $(I R R)$ of 12 percent for basic education and 10 percent for upper-level education. The associated values for $R_{u}$ and $R_{b}$ are

in secondary+ education converts thirty low-skill workers into high-skill workers, with eight workers drawn from sector $n$ and twenty-two from sector $x$ - $j$. If four of the eight workers drawn from sector $n$ would have been unemployed, then four jobs open up in the formal sector. If $\xi=0.5$, two of the jobs are filled by workers from $x-j$. Hence $\Delta_{x j}=0.80$.

${ }^{40}$ The urban labor force is $\bar{L}_{o}-L_{x o}+S_{o}-S_{x o}$.

${ }^{41}$ Both types of oversampling are known to inflate estimated returns to education.

${ }^{42}$ See also Schultz (2004), Colclough et al. (2010), and Diagne and Dienne (2011), where the estimated private return to primary education is 49- 66 percent lower than the average estimate for LICs in the Psacharopoulos and Patrinos (2004) survey. 
backed out from expressions such as (49) for a time lag of six years for basic education and eight years for upper-level education. Many development economists would disagree with the $I R R$ s we have assumed for the base case, citing the insignificant effects of education variables in cross-country growth regressions (Pritchett, 2001) and the very poor educational outcomes in LICs as evidence that $I R R$ s are probably much lower than 10-12 percent. The scepticism is justified. There $i s$ a great deal of uncertainty about the true returns to education in LICs. We discuss in Section VII the implications for the optimal investment mix of reducing $I R R_{u}$ and $I R R_{b}$ to $5-8$ percent.

- Residual financing of the fiscal deficit $\left(\lambda_{d c}\right)$. Domestic and external commercial debt adjust endogenously to cover the residual financing gap. The share of of the gap allocated to external commercial debt equals its initial share in non-concessional debt - i.e., $\lambda_{d c}=\frac{d c_{0}}{d c_{0}+P_{0} b_{0}}$.

- The long-run target for commercial debt $\left(d c^{\text {target }}\right)$ and the division of fiscal adjustment between expenditure cuts and tax increases $(\lambda)$. Across steady states, non-investment expenditure and taxes share the burden of fiscal adjustment equally $(\lambda=0.5)$ and commercial loans are repaid in full $\left(d c^{\text {target }}=d c_{0}\right)$.

The numerical simulations are free of approximation error - in all scenarios, they simulations track the global non-linear saddle path. The solutions were generated by a set of programs written in Matlab R2017b and Dynare 4.4.3.

\section{The Long-Run Trade-offs of Different Types of Public Investment}

The general equilibrium interactions in the model are intuitive but also complex. It will prove helpful in understanding the results in Section VI and VII to first analyze the effects of each type of public investment in isolation.

\section{A. Increasing Investments One at a Time}

Table 4 shows how an increase in public investment equal to 1 percent of initial GDP affects real output, aggregate consumption (or Net National Income), the aggregate private capital stock $\left(k=k_{x}+k_{n}+k_{j}\right)$, sectoral output and employment, the unemployment rate, real wages, real income 
of the ex ante poor $(E A P G)$, and the relative prices of the formal and informal goods. ${ }^{43} C I C$ is the crowding-in coefficient, the ratio of the increase in real private investment to the increase in real public investment. The VAT and all other taxes are held constant, so the change in transfers (divided by initial GDP) measures the net fiscal gain/loss.

We present two solutions for each investment program. When $\varepsilon_{3}=0.5$, output of the formal sector has no close substitutes; it is a pure non-traded good. In the other solution, where $\varepsilon_{3}=5$, the formal sector produces both non-traded services and differentiated varieties highly substitutable with similar varieties of imported consumer goods. ${ }^{44}$

The numbers for everything - GDP, the unemployment rate, real wages, sectoral employment, etc. - differ substantially with the composition of public investment and the tradability of formal sector output. Four results stand out:

- In the long run, investment in basic education strongly dominates investment in infrastructure. Investment in basic education (IBE) increases GDP, formal sector employment, and real wages 2 - 2.5 times as much as investment in infrastructure (II). The outsized gains stem from potent, positive, mutually-reinforcing general equilibrium effects. Balanced sectoral growth minimizes the decrease in $P_{n}$ and thereby promotes strong expansion in the formal sector. The boom in the formal sector, in turn, fuels a boom in private capital accumulation and large secondary gains in aggregate labor productivity - the supply of good high-wage jobs increases 5 percent. Strong crowding-in of private capital also lessens the toll of diminishing returns: across steady states, the returns to investment in infrastructure and upper-level education drop 14 - 15 percent and 33-40 percent, respectively; for investment in basic education, the return decreases only 6 percent (from 30 percent to 28.1 percent). One way to quantify the contribution of the potent pro-growth general equilibrium effects is to reduce $R_{b}$ from 30 percent to 20 percent, the net return on infrastructure investment. Panel (c) shows the results for this run. Strikingly, although $R_{b}$ is the same as $R_{z}$, aggregate consumption increases 60 - 90 percent more and real income of the poor 35 percent more than with II.

- Investment in upper-level education also strongly dominates investment in infrastructure. Because it is highly capital intensive and faces a relatively flat supply curve for hiring low-skill labor, the formal sector is the most dynamic sector in the economy. Moreover, as the most skillintensive sector in the economy, the formal sector benefits disproportionately from an increase in the supply of skilled labor. It is not surprising therefore that investment in upper-level education

\footnotetext{
${ }^{43} E A P G$ includes the income gains of the ex ante poor who become skilled workers or obtain a high-wage job in the formal sector. The increase in aggregate consumption equals the increase in Net National Income across steady states.

${ }^{44}$ Suppose that nontraded goods/services account for half of formal output. When the elasticity of substitution between domestic manufactured varieties and imported varieties is 10 (a common value in macroeconomic models), the overall elasticity of substitution between formal sector output and imported consumer goods is 5.25.
} 
(IUE) reduces unemployment much more and generates much larger increases in GDP, aggregate consumption, real wages for low-skill labor, and real income of the ex ante poor $(E A P G)$ than II. In the run with $\varepsilon_{3}=5$, it is also much more effective in crowding in private capital and increasing the supply of high-wage formal sector jobs for low-skill labor. Again, the complete dominance of II is not an artifact of $R_{u}$ being ten percentage points higher than $R_{z}$. Even when $R_{u}=R_{z}$ as in Panel (e), investment in upper-level education scores better than II.

- The impact of IUE on GDP, the supply of good high-wage jobs, and the government budget constraint is sensitive to the tradability of formal sector output. The formal sector is far more dynamic than agriculture or the informal sector. What constrains expansion in the sector is the decrease in its relative price. The elasticity of demand for the formal good has little effect on the results for II and IBE, which deliver roughly balanced growth. It makes a big difference, however, in the case of IUE. Macroeconomic returns are much higher when formal sector output is highly tradable and the supply curve shifts out against a relatively flat demand curve. Compare the results for $\varepsilon_{3}=0.5$ and $\varepsilon_{3}=5$ in Panel (d). In the run for $\varepsilon_{3}=5$, GDP increases another three percentage points and formal sector (low-skill) employment and output another 11 percentage points. Note also that the net fiscal impact of IUE is highly sensitive to the tradability of formal sector output. Since the formal sector provides the bulk of VAT and income tax revenue, there is a risk with IUE that a large decrease in $P_{n}$ will severely erode the tax base. When $\varepsilon_{3}=5$, strong expansion in the formal sector offsets the large decrease in $P_{n}$, giving rise to a small fiscal surplus. By contrast, when the sector's output is non-tradable, endogenous revenue gains cover only 36 percent of the investment bill.

- The choice between IUE and IBE entails a growth-inequality tradeoff. Policy makers face a tradeoff when comparing the gains from IUE with those from IBE. The GDP comparison favors IBE, but IUE does more to reduce poverty: real income of the ex ante poor increases an additional eight percentage points both for $\varepsilon_{3}=0.5$ and $\varepsilon_{3}=5$. In the latter case, where the GDP differential is small, IUE is certainly competitive with if not superior to IBE.

\section{B. The High Cost of Underfunding Maintenance}

Maintenance increases net investment by reducing the depreciation rate. Unlike new investment, however, spending more to correct suboptimal maintenance immediately increases Net National Product $(N N P)$. It is possible therefore to increase net investment, without lowering consumption, by shifting funds from gross investment to maintenance. Up to a point, higher spending on maintenance is truly a free lunch. ${ }^{45}$

\footnotetext{
${ }^{45}$ See Adam and Bevan (2014) for a slightly different take on the free-lunch result. Working with a more detailed specification of $\mathrm{O}+\mathrm{M}$, they demonstrate that inadequate maintenance increases the fiscal deficit for a given level of
} 
Consider the following simple model in continuous time:

$$
\begin{aligned}
& c=q(z)-\mathcal{T}, \\
& \mathcal{T}=i_{z}+\overline{\mathfrak{m}} z,
\end{aligned}
$$

and

$$
\dot{z}=i_{z}-\delta_{z} z
$$

where $\delta_{z}=\delta_{z 0} e^{-\Lambda \overline{\mathfrak{m}}}$ and $\overline{\mathfrak{m}} \equiv \mathfrak{m} / z$. Substituting for $\mathcal{T}$ in (50) gives

$$
c=q(z)-i_{z}-\overline{\mathfrak{m}} z
$$

Seeking a free lunch, at $t=0$ the government pairs a permanent decrease in $i_{z}$ with an offsetting increase in $\mathfrak{m}$. Since $d i_{z}+d \mathfrak{m}=d i_{z}+z_{0} d \overline{\mathfrak{m}}$, there is no effect on $\mathcal{T}$ or $c$. But

$$
\left.\dot{z}\right|_{t=0}=\left.\left.\left(\Lambda \delta_{z}-1\right) z_{0} d \overline{\mathfrak{m}}\right|_{t=0} \quad \Longrightarrow \quad \dot{z}\right|_{t=0}=\left.\left(R_{\mathfrak{m} z}-1\right) z_{0} d \overline{\mathfrak{m}}\right|_{t=0}=\left.d N N P\right|_{t=0}
$$

as $\Lambda \delta_{z}=R_{\mathfrak{m} z}$, the return on maintenance relative to new investment. When maintenance is underfunded, $R_{\mathfrak{m} z}>1$ and the increase in net investment is paid in full by the increase in $N N P$. Assuming the increase in $\overline{\mathfrak{m}}$ is permanent (i.e., $\dot{\mathfrak{m}}=\overline{\mathfrak{m}} \dot{z}, t>0$ ), $c$ rises monotonically with $z$ on the transition path to the new steady state (Figure 1). In the long run,

$$
d z=\left(R_{\mathfrak{m} z}-1\right) \frac{z}{\delta_{z}} d \overline{\mathfrak{m}} \quad \text { and } \quad \frac{d c}{c}=\left(R_{\mathfrak{m} z}-1\right)\left(\frac{R_{z}}{\delta_{z}}+1\right) \frac{z}{c} d \overline{\mathfrak{m}}
$$

The import of the second equation in (53) is that the free lunch is also a big lunch, e.g., when $R_{\mathfrak{m} z}=1.6$, $R_{z}=.20, \delta_{z}=.075$, and $z / c=1$, the coefficient multiplying $d \overline{\mathfrak{m}}$ equals $2.2{ }^{46}$

Table 5 quantifies the cost of neglecting maintenance in the DIG-Labor 1 model. The run in Panel (b) starts from an equilibrium with gross underfunding of maintenance: $\mathfrak{m}=0$ slices 6.6 years off the service life of infrastructure (the depreciation rate is 7.46 percent) and raises the return on maintenance 49 percent above the return on new investment at the initial steady state. Spending 1.64 percent of GDP on maintenance eliminates the return gap and increases GDP 9.1-10 percent and aggregate consumption 8.3-9.1 percent, with the free lunch component delivering 35-39 percent of the total gains. These gains are twice as large as the gains produced by increasing new investment 1 percent of GDP; note also that after taking into account the free lunch (0.49 percent of GDP) and the larger endogenous increase in tax revenue, the net fiscal cost is lower by 0.28-0.42 percent of GDP.

infrastructure capital.

${ }^{46}$ Typically $z / c$ is slightly above unity. (For the base case calibration values in Table 3 , it equals 1.1 .) $R_{m z}=1.6$ might be very conservative. According to empirical estimates and countless case studies, the return to $m$ is $2-5$ times higher than the return to $i_{z}$ (Heggie and Vickers, 1998; Briceno-Garmendia and Foster, 2010, Chapter 2). We cannot muster the nerve to set $R_{m z}$ equal to 5 . 


\section{Big-Push Investment Programs}

Figure 2 relates the ranking of public investments in human capital and infrastructure in SubSection A. to the results for big-push investment programs in this section. The MR schedules show how the marginal general equilibrium return (i.e., the increase in NNI) to investment $i_{j}$ declines, holding investment in other types of public capital constant. For small changes of the sort considered in Table 3, IBE pays the highest return, followed - much further down the vertical axis — by IUE and II. ${ }^{47}$ It would be wrong to infer from this, however, that there is no role for investment in infrastructure or upper-level education in the optimal big-push program. IUE increases real income of the poor much more than IBE. Moreover, the three capital stocks are strong gross complements: an increase in one component of public capital increases the productivity of the other two components, shifting their MR schedules vertically upward. In our base case calibration, the combination of diminishing returns, strong gross complementarity, and a non-trivial weight on distributional objectives - a willingness to trade slightly less growth for more inclusive growth - ensures a sizeable share for IUE in the optimal investment program. The fate of II is less certain. NNI increases less and poverty decreases less when some investment shifts from human capital to infrastructure. But only in the long run. Because investment in education increases labor productivity with a 6 - 8 year lag, it takes more than a decade for the paths of NNI, real wages for the poor, and formal sector employment in an all-human-capital investment program to overtake the corresponding paths in a mixed infrastructure + human capital program. The preferred program depends on how policy makers evaluate this intertemporal trade-off. We discuss this issue in depth in Sections VI and VII.

\section{Pure vs. Mixed Investment Programs}

Table 6 quantifies the long-run effects of big-push programs that permanently increase public investment by 4 percent of initial GDP. Panels (a), (b), and (c) assume all investment goes either to infrastructure or human capital, while Panels (d) and (e) allocate 25 - 40 percent of investment to infrastructure.

As expected, investing only in infrastructure is highly inefficient. The numbers in Panel (a) are perfectly satisfactory viewed in isolation. But they pale in comparison with the gains generated by programs that invest mainly or entirely in human capital. Substituting one of the investment programs in Panels (b) - (d) for the all-infrastructure program in Panel (a) increases NNI 21-27 percentage points, real wages in the informal sector 17-25 percentage points, and real income of the ex ante poor 19-37 percentage points. The belief that development is best served by building stuff instead of

\footnotetext{
${ }^{47}$ In the case of IUE, the MR gap is only one percentage point when $\varepsilon_{3}=5$.
} 
investing in people is an expensive fallacy.

\section{E. Ranking Some of the Contenders}

A complete, rigorous ranking of the investment programs in Panels (b) - (e) awaits information on the transition path and a formal welfare analysis. We are confident, however, on the basis of just the long-run results in Table 6, that the all-human-capital program that invests 33 percent in upper-level education and 67 percent in basic education dominates the program that invests 100 percent in basic education. This is obvious in the run where formal sector output is highly tradable. The numbers for NNI, real income of the ex ante poor, good high-wage jobs for low-skill labor in the formal sector, and unemployment - the most important numbers - are all much better in Panel (c) than in Panel (b). In the run where formal sector output is non-tradable $\left(\varepsilon_{3}=0.5\right)$, choosing Panel (c) over Panel (b) sacrifices one percentage point of NNI in exchange for increasing real income of the ex ante poor an additional 17 percentage points. If the commitment to inclusive growth means anything at all, policy makers will happily accept the trade-off.

There are no other easy calls in Table 6. The all-human-capital program in Panel (c) generates significantly larger increases in NNI and real income of the poor than the programs in Panels (d) and (e) that dedicate 25 - 40 percent of investment to infrastructure. But, to repeat, investment in human capital affects productivity with a long lag. Consequently, the mixed infrastructure + human capital programs deliver larger development gains than the all-human-capital program over a lengthy medium run. All we can say at this point is that the ranking of the investment programs in Panels (c) - (e) depends on policy makers' social discount rate.

\section{The Transition Path}

Figures 3 and 4 show the transition paths associated with the big-push investment programs presented in Table 6. We start with a comparison of the two boundary cases, the all-infrastructure program and the all-human capital program, which highlights the principal inter-temporal trade-offs that need to be navigated by policy makers (Figure 3). The first of these arises from the long gestation lags associated with investment in human capital: while the all-human capital program dominates the all infrastructure program in the long-run, these returns take much longer to realize. It is true we assume infrastructure projects to be 'shovel-ready' — so that returns to infrastructure are realized only one period after the investment takes place — but even complex infrastructure investment projects are likely to come on stream substantially quicker than most human capital investments. The returns 
to human capital investment will still be heavily deferred relative to those from infrastructure investment. Second, big-push investment programs all involve a substantial scale-up in public investment - 4 percent of initial GDP in the long run, with a degree of front-loading, and with maintenance expenditure rising in line with the public capital stock - which places a substantial and sustained fiscal burden on the economy during the transition period, a burden that significantly overshoots the steady-state fiscal costs reported in Table 6. Third, the corollary of the deferred aggregate returns to human capital investment is that the associated long-run poverty-reduction gains are also heavily delayed, and indeed over the short-term the ex ante poor do worse in this scenario than if public investment is specialized in physical infrastructure.

Across all the runs considered here, we assume domestic political economy considerations place limits on the degree of domestic fiscal financing so that overall feasibility requires substantial external (concessional) financing. Specifically, we assume that the VAT rate cannot increase by more than 2 percentage points above its initial level (of 20 percent) and that government is unable to reduce transfers to households by more than 1 percentage point of initial GDP. At the same time, though, we allow for fiscal reforms to broaden the tax base so that over a period of a decade a steadily increasing proportion of domestic consumption of the agricultural and informal goods is taxed (the tax base widens from 10 percent of agricultural consumption to 30 percent and from 30 percent to 60 percent of the non-agricultural informal good). The remainder of financing is met by (exogenous) concessional borrowing equivalent to 24 percent of initial GDP over 8 years, which is repaid over the next 14 years, with a blend of non-concessional external and domestic borrowing delivering the residual fiscal financing. ${ }^{48}$ These runs are for the case where we assume the formal good is highly substitutable with the import good (i.e., $\varepsilon_{3}=5$ ).

\section{A. Growth and Structural Change}

We have already examined the long-run growth effects of public investment programs. What is clear from the transition paths, however, is the strength of the inter-temporal trade-off. The more the public investment program (PIP) is skewed in favor of investment in human capital, the stronger longrun growth, structural transformation, and poverty reduction, but the weaker are the development gains in the short-run. Thus while output and consumption per capita and real wages for both formal and informal sector workers grow by about twice as much after 40 years when investment is specialized in human capital, the gains over the first decade are pretty nugatory. Private investment slumps, aggregate consumption and real wages stagnate, and there is no measurable improvement in the incomes of the ex ante poor. When the returns to education start to flow, however, private

\footnotetext{
${ }^{48}$ In the base run, 30 percent of the residual financing gap is met from external concessional borrowing with 70 percent from domestic borrowing.
}

CInternational Monetary Fund. Not for Redistribution 
investment surges, growth takes off and structural change begins to occur.

The key driver is the change in the supply and productivity of labor. During the incubation period, investment in human capital leaves the supply side of the economy unchanged. Hence, over this period, with no change in the productivity of aggregate labor, the spending effect of the debt-financed increase in aggregate demand sees the real exchange rate appreciate and production and consumption shift away from the tradable (agricultural) sector and the formal sector toward the non-traded informal sector. ${ }^{49}$ By contrast, when the PIP is channeled to physical infrastructure, the complementarity of public capital with private factors increases the demand for labor in the formal sector, moderating the real exchange rate appreciation and associated movement out of the tradable sector.

As the effects of education yield fruit in the medium term, three things happen. First, upper-level education increases the supply of skilled labor available to all three sectors, with the relatively skillintensive formal sector enjoying the strongest boost. Since there is no unemployment of skilled labor in the economy, the increase in supply sees a sharp decline in the skilled wage premium. Second, basiclevel education increases effective unskilled labor to all three sectors and further strengthens output growth across the economy. Together, both labor supply effects drive up the marginal product of capital further, boosting private investment. Finally, the combination of upper-level education converting unskilled labor into skilled labor, the decline in unemployment, and rising labor productivity from basic education across all sectors sees the incomes of the ex ante poor rise sharply and more rapidly than aggregate income.

The crossing point in this experiment is around year 15, some 6 to 7 years after the returns to education first hit the economy (although the private sector investment response is somewhat more attenuated). Though the benefits are large, this is a long time to wait. Of course, if public investment in education begins to pay off more rapidly, for example if students at all grades rather than just the entry cohort benefit from higher spending, and/or infrastructure spending takes longer before it starts to generate returns, the difference between the two programs becomes much less stark.

\section{B. Fiscal Adjustment and Debt Dynamics}

Transformative public investment programs of the scale considered here necessarily entail a substantial fiscal burden, especially when the incubation period is long. Unless we allow for an implausible degree of domestic fiscal flexibility, this means large external resource flows, which in the absence of unrequited aid grants means external debt financing is required to fill the gap. Again, the long gestation period for investment in human capital plays an important role here. Though the investment

\footnotetext{
${ }^{49}$ Although not reported here, the contraction of the formal sector is much weaker when the formal good is effectively non-tradable (i.e. $\varepsilon_{3}=0.5$ ).
} 
cost is comparable across programs, the all-human capital PIP sees the tax rate and transfers hit their limits sooner and stay there longer while the total public debt burden is around 8 - 10 percentage points of GDP higher for almost 40 years compared to the infrastructure-only case.

The fiscal configuration shown here is relatively favorable. Concessional financing is available on generous terms (the rate of interest is 1.3 percent against a market rate of 6 percent and repayment commences after 9 years) while non-concessional external borrowing is modest (rising by 2 percentage points of initial GDP during the investment phase, and by a further 2 percentage points during the period concessional debt is being repaid). Moreover, while we assume limits on the extent to which the tax rate can be increased, we have allowed for a measure of base expansion that, in the initial equilibrium, generates an additional 2 percent of GDP in revenue. Even so, with this structure, total public debt peaks at around 80 percent of GDP (relative to an initial level of 55 percent of GDP) in the human capital-only PIP and at 70 percent in the infrastructure-only PIP. Faced with reduced access to concessional borrowing and less effective base expansion, the fiscal program would quickly be rendered infeasible, especially if the government faced a rising risk premium on commercial debt. It is, however, a straightforward matter to explore the boundaries of the fiscal space under a range of alternative financing rules.

\section{Blended Public Investment Programs}

Figure 4 reproduces the transition path for the blended PIP shown in Table 6, panel (d), for the case where $\varepsilon_{3}=5$. Qualitatively, the results remain very similar although blending necessarily operates on both ends of the trade-offs. With less human capital investment in the mix, the long-run gains are reduced, but at the same time the tendency towards up-front stagnation is slightly, but not completely, diminished. In contrast to the all human capital case, the mixed investment program avoids outright contraction in aggregate consumption.

\section{Intertemporal Trade-offs: Summary}

These transition paths throw into sharp relief the powerful intertemporal trade-offs that must be negotiated when considering investment in slow-maturing human capital. Even when long-run returns are high and certain, policymakers must steer the economy through a protracted period of low growth and a heavy fiscal burden before reaping the positive growth and distributional gains that investment in human capital will deliver. Whether it is in their interest to do so will, of course, depend on how heavily they discount the future and how much weight they place on the poverty reduction engineered by investment in human capital. For this we need to turn to some welfare calculations.

CInternational Monetary Fund. Not for Redistribution 


\section{Welfare Calculations}

In the absence of detailed household disaggregation, the most natural way to incorporate the welfare effects of poverty reduction among the ex-ante poor is to include their real income in the social welfare function:

$$
S W=\sum_{t=0}^{\infty} \beta_{s}^{t} \frac{\left(c_{t}+\zeta E A P Y_{t}\right)^{1-1 / \tau}}{1-1 / \tau},
$$

where $c_{t}$ is aggregate consumption, $\beta_{s}$ is the social discount factor, $E A P Y_{t}$ is income of the ex ante poor, and $\zeta$ is a measure of the relative welfare weight placed on income of the ex ante poor.

Since the model does not allow us to directly identify the consumption of the ex ante poor within aggregate consumption $c_{t}$, we are forced to rely on the income of this group as an imperfect proxy for their consumption. ${ }^{50}$ Note, however, that if $E A P Y_{t}$ tracked consumption of the ex ante poor perfectly, $1+\zeta$ would measure the marginal rate of substitution between consumption of the ex ante poor and the consumption of the non-poor in social welfare. The results reported in Tables 7 - 9 report results for $\zeta=0, \zeta=1$, and $\zeta=2$.

The second relevant choice is the policy makers' choice of social discount factor, $\beta_{s}$. In both developed and less-developed countries, the social discount factor used to calculate the cost-benefit ratio for public sector projects is usually much higher than the private counterpart. The HM Treasury (2018) Green Book: Guidance on Appraisal and Evaluation recommends $\beta_{s}=0.966-0.979$ (and as high as 0.993 for health-related projects), substantially above the private value of $\beta=0.93$ used here. Theory cannot tell us whether these elevated discount factors are sensible, HM Treasury notwithstanding. It does, however, offer cogent arguments for $\beta_{s}>\beta$. In Sen's (1967) isolation paradox, private savings is sub-optimal because individuals would be willing to enter into a social contract that required everyone to save more. Feldstein (1964) and Baumol (1965) reach the same conclusion more quickly by appealing to the notion that economic development is partly a public good; if the premise is granted, then the social discount rate "must be administratively determined as a matter of public policy [because] the market cannot express the 'collective' demand for investment to benefit the future" (Feldstein, 1964, pp. 362, 365).

While policymakers may not know what the social discount factor is, their value of $\beta_{s}$ can be elicited directly from the answer to the question: abstracting from all other factors that cause the social return to capital to differ from its private return, what is the value of one dollar of aid that

\footnotetext{
${ }^{50}$ To directly track their consumption we would have to define and solve the optimization problem of a distinct household group consisting of the ex ante unemployed, plus those who, ex post, secure low-skilled jobs in the formal sector and those that become high-skill workers.
}

(CInternational Monetary Fund. Not for Redistribution 
permanently increases private investment relative to one dollar of aid that permanently increases private consumption? If the answer is $X$, then

$$
\frac{1-\beta(1-\delta)}{1-\beta_{s}(1-\delta)} \frac{\beta_{s}}{\beta}=X
$$

$X>1$ signifies a preference for investment and, implicitly, a value of $\beta_{s}>\beta$. In our base case calibration where $\beta=0.93$ and $\delta=0.05$, for example, $X=1.25,1.50$, and 1.75 imply $\beta_{s}=0.952$, 0.968 , and 0.979 .

Tables 7 to 9 measure the welfare gains in our baseline big-push investment program for alternative shares of investment in physical infrastructure $\left(i_{z}\right)$ and human capital. In all cases, we hold constant the split between upper-level education $(1 / 3)$ and basic education $(2 / 3)$, reflecting the results from Table 6 , and then vary the split between investment in physical infrastructure and in the composite human capital. We restrict the reporting to cases where the formal good is tradable $\left(\varepsilon_{3}=5\right)$ as the results are robust to variations in this parameter. For each table we report separate panels of alternative values of the weight on poverty-reduction, $\zeta$, and vary the value of the social discount factor from $\beta_{s}=\beta=0.93$ to $\beta_{s}=0.98$, the top end of the HM Treasury range for non-health investments. Table 7 reports the compensating variation for the baseline returns to education case, while in Tables 8 and 9 we allow for much lower rates of return to investment in human capital.

The results are consistent with the patterns observed on the transition path. In the base case (Table 7), when the policy maker ignores the public good element of the investment program so that the social discount rate is the same as the private $\left(\beta_{s}=\beta=0.93\right)$, between a quarter and a half of the welfare-optimal big push program consists of investment in physical infrastructure. As the policy maker places more weight on the future gains — so that the effect of the gestation lags in human capital weigh less heavily on the welfare calculus — and/or place more weight on redistribution, the optimal share of physical infrastructure falls away. At a social discount factor of $\beta_{s}=0.96$, towards the bottom end of the Treasury Green Book guidelines, the optimal spending mix involves at most 25 percent investment in infrastructure and at least 75 percent in human capital, which generates substantially larger social welfare gains (the compensating variation is approximately twice as large). When policy makers operate with a discount factor at the top end of the Treasury range and where the weight on policy reduction is high, the optimal program consists almost entirely of investment in human capital.

As the estimated returns to human capital decrease, the welfare gains from mixed investment programs decline and the optimal share of infrastructure rises. In Table 8, the $I R R s$ for basic- and upper-level education are reduced from 12 percent and 10 percent, respectively, to 9.3 percent and 8.1 percent, in which case the optimal infrastructure share in investment rises to between 35 percent and 50 percent for $\beta_{s}=0.96$. When the IRRs are 7.6 percent and 6.7 percent, as per Table 8, 
infrastructure accounts for the lion's share of the optimal program for all but the highest level of the social discount factors. It is striking, however, that these welfare surfaces are very flat and so it would require a mixture of substantial pessimism on the returns to education, comparatively high social discounting and a low weight on poverty reduction, and a complete disregard of the merit-good returns to education to overturn a welfare-based argument that the optimal public investment program should be build around significant investment in human capital.

\section{Where to From Here?}

The DIG-Labor models enable policy makers to analyze how big-push public investment programs with different mixes of investment in human capital and infrastructure affect growth, debt, and various dimensions of inequality and poverty in economies where payment of EWs gives rise segmented labor markets, underemployment, and involuntary unemployment.

At present, there are three variants of DIG-Labor. In DIG-Labor 1, the model examined at length here, EWs operate only in the formal sector and open unemployment coexists with extensive underemployment. This is the model of choice for most LICs. DIG-Labor 2 differs from DIG-Labor 1 in that EWs prevail in both the formal and non-agricultural informal sector. It is the preferred model for the great majority of MICs and EMEs. DIG-Labor 3 is for those who acknowledge the existence of underemployment but do not believe that involuntary unemployment is a real phenomenon in LDCs. Although we disagree with the model's premise, we include it to facilitate debate between policy makers who hold different views about the nature of the labor market.

In future research we hope to furnish the DIG-Labor suite with more and better models. Labor markets in the world's 140+ LDCs exhibit a bewildering diversity. It is not hard therefore to find countries with labor market structures not covered by DIG-Labor 1-3. At a minimum, DIG-Labor 1 - 3 needs to expand to DIG-Labor 4- 6 to account for unemployment/underemployment of high-skill labor, wage and productivity gaps between estate and smallholder agriculture, and binding minimum wage laws: 51

- Casual observation and a fair bit of hard data suggest that the assumption in DIG-Labor 1-3 of flexible wages and an integrated labor market for educated workers is often dubious or flat out wrong. In some countries high rates of unemployment and underemployment of educated workers reflect a mismatch between the skills employers desire and those acquired by secondary

\footnotetext{
${ }^{51}$ This list is not exhaustive. In some country applications, it may be important to allow for external migration of skilled labor or to explicitly model public sector employment (e.g., when privatization or downsizing of the parastatal sector is part of a program to create more fiscal space for core investments in infrastructure and education).
}

CInternational Monetary Fund. Not for Redistribution 
school and university graduates, but in others the evidence points to a shortage of high-skill jobs stemming from payment of EWs in the formal sector.

- In much of Latin America and parts of Sub-Saharan Africa, the estate sector accounts for a large share of agricultural output. Typically wages and labor productivity are substantially higher than on smallholder farms. Efficiency wage effects and monopsony power in the estate sector provide the most likely explanations for the productivity and earnings gaps (Azam, 1997; Devereux, 2005).

- Binding minimum wage laws set wages in the formal sector in many MICs and EMEs and are likely to become increasingly relevant in LICs over the next 10-15 years. Given the abundant empirical evidence in support of EW effects throughout the formal sector and, in the case of MICs and EMEs, in the informal sector as well, DIG-Labor seems the ideal framework for analyzing the economy-wide repercussions of minimum wage increases in the short, medium, and long run. And while debt sustainability is not a frontline issue as in big-push public investment programs, there are first-order effects on the fiscal budget when minimum wage increases encompass both the public and private sector.

The second, complementary task for future research is to make all of the DIG-Labor models better by incorporating health as a separate component of human capital. Originally we thought this was unnecessary, reasoning that health affects the productivity of low-skill labor in the same way as basic education.

We were wrong. Diminishing returns to any single component of public capital and gross complementarity of different types of public capital guarantee that the overall return to human capital will be higher when the investment program includes spending on health. Moreover, the results from random clinical trials argue that complementarity of health and education is exceptionally strong in LICs (Miguel and Kremer, 2004; Bobonis et al., 2006; Baird et al., 2011). This bears on the right interpretation of estimated returns to education. When the return to basic education is depressingly low in some LICs, is it because the quality of education is depressingly low? Maybe not. Maybe children suffering from anemia, stunting, chronic diarrhea, and intestinal worms cannot learn even at schools that offer the chance for a good education. 


\section{References}

Abuhadba, M., and P. Romaguera, 1993, "Inter-Industrial Wage Differentials: Evidence from Latin American Countries." Journal of Development Studies 30, 190-205.

Adam, C., and D. Bevan, 2014, "Public Investment, Public Finance, and Growth: The Impact of Distortionary Taxation, Recurrent Costs, and Incomplete Appropriability." IMF Working Paper No. 14/73 (International Monetary Fund).

Adam, C., and E. Buffie, 2020, "The Minimum Wage Puzzle in Less Developed Countries: Reconciling Theory and Evidence." IMF Working Paper (forthcoming).

Akerlof, G., 1982, "Labor Contracts as Partial Gift Exchange." Quarterly Journal of Economics 97, 543-569.

African Development Bank, 2018, "African Economic Outlook 2018," Report.

Agenor, P.-R., and P. Montiel, 2015, Development Macroeconomics, 4th edition (Princeton, Princeton University Press).

Aigbokhan, B., 2011, "Efficiency Wage, Rent-Sharing Theories and Wage Determination in the Manufacturing Sector in Nigeria." AERC Research Paper 222. (African Economic Research Consortium).

Akitoby, B., A. Baum, C. Hackney, O. Harrison, K. Primus, and V. Salins, 2018, "Tax Revenue Mobilization Episodes in Emerging Markets and Low-Income Countries: Lessons From a New Dataset." IMF Working Paper No. 18/234 (International Monetary Fund).

Albala-Bertrand, J. and E. Mamatzakis, 2001, "Is Public Infrastructure Productive? Evidence from Chile." Applied Economics Letters, 195-198.

Alcaraz, C., D. Chiquiar, and M. Ramos-Francia, 2011, "Wage Differenentials in Mexico's Urban Labor Market." Economics Bulletin 31, 250-258.

Alcaraz, C., 2009, "Informal and Formal Labor Flexibility in Mexico." Revista Desarollo y Sociedad, First Semester, 115-143.

Alvarez, J., 2020, "The Agricultural Wage Gap: Evidence from Brazilian Micro-Data." American Economic Journal: Macroeconomics 12, 153-173.

Appleton, S., L. Song, and Q. Xia, 2005, "Has China Crossed the River? The Evolution of Wage Structure in Urban China During Reform and Retrenchment." Journal of Comparative Economics 33, 644-663.

Arango, L., N. Obando, and C. Esteban Posada, 2010, "Sensibilidad de los Salarios de Desempleo Regional en Colombia: Nuevas Estimaciones de la Curva de Salarios." Borradores de Economia No. 590/2010 (Banco de la Republica).

Araujo, J., A. David, C. van Hombeeck, and C. Papageorgiou, 2015, "Non-FDI Capital Inflows in Low-Income Countries: Catching the Wave?" IMF Working Paper No. 15/86 (International Monetary Fund).

Arbache, J., 2001, "Wage Differentials in Brazil: Theory and Evidence." Journal of Development Studies 38, 109-130. 
Arthi, V., K. Beegle, J. De Weerdt, and A. Palacios-Lopez, 2018, "Not Your Average Job: Measuring Farm Labor in Tanzania." Journal of Development Economics 130, 160-172.

Asian Development Bank, 2017. "Meeting Asia's Infrastructure Needs." (Manila).

Aslam, A., E. Berkes, M. Fukac, J. Menkulasi, and A. Schimmelpfennig, 2014. "Afghanistan: Balancing Social and Security Spending in the Context of a Shrinking Resource Envelope," Asian Development Review 31(2), 165-197.

Atolia, M., B. Li, R. Marto, and G. Melina, 2019, "Investing in Public Infrastructure: Roads or Schools?" Macroeconomic Dynamics, 1-30.Y.

Azam, J., 1997, "Efficiency Wage and the Family: An Explanation for the Impact of the Agricultural Minimum Wage in Morocco." Kyklos 50(3), 369-382.

Badaoui, E., E. Strobl, and F. Walsh, 2010, "The Formal Sector Wage Premium and Firm Size." Journal of Development Economics 91, 37-47.

Baird, S., J. Hicks, M. Kremer, and E. Miguel, 2011, "Worms at Work: Long-run Impacts of Child Health Gains." Working Paper.

Baltagi, B., Y. Baskaya, and T. Hulagu, 2013, "How Different are the Wage Curves for Formal and Informal Workers? Evidence from Turkey." Papers in Regional Science 92, 271-283.

Baltagi, B., Y. Baskaya, and T. Hulagu, 2012, "The Turkish Wage Curve: Evidence from the Household Labor Force Survey." Economics Letters 114, 128-131.

Baltagi, B., B. Rokicki, and K. de Souza, 2017, "The Brazilian Wage Curve: New Evidence from the National Household Survey." Empirical Economics 53, 267-286.

Banerjee, A., and E. Duflo, 2011, Poor Economics (Public Affairs).

Bargain, O., and P. Kwenda, 2014, "The Informal Sector Wage Gap: New Evidence Using Quantile Estimations on Panel Data." Economic Development and Cultural Change 63, 117-153.

Barouni, M., and S. Broecke, 2014, "The Returns to Education in Africa: Some New Estimates." Journal of Development Studies 50, 1593-1613.

Baskaya, Y., and T. Hulagu, 2011, "Informal-Formal Worker Wage Gap in Turkey: Evidence From a SemiParametric Approach." IZA Discussion Paper No. 6556 (Institute for the Study of Labor Economics).

Baumol, W., 1965, Welfare Economics and the Theory of the State (G. Bell and Sons).

Beegle, K., J. de Weerdt, and S. Dercon, 2011, "Migration and Economic Mobility in Tanzania: Evidence from a Tracking Survey." Review of Economics and Statistics 93, 1010-1033.

Ben Salem, M., and I. Bensidoun, 2012, "The Heterogeneity of Informal Employment and Segmentation in the Turkish Labour Market." Journal of the Asia Pacific Economy 17, 578-592.

Berg, A., E. Buffie, C. Pattillo, R. Portillo, A. Presbitero, and L.-F. Zanna, 2019, "Some Misconceptions About Public Investment Efficiency and Growth.” Economica 86, 409-430.

CInternational Monetary Fund. Not for Redistribution 
Berg, J., and D. Contreras, 2004, "Political-Economic Regime and the Wage Curve: Evidence from Chile, 1957-1996." International Review of Applied Economics 18, 151-165.

Berry, A., and R. Sabot, 1978, "Labor Market Performance in Developing Countries: A Survey." World Development 6, 1199-1242.

Berry, A., and R. Sabot, 1984, "Unemployment and Economic Development." Economic Development and Cultural Change 33, 99-116.

Betcherman, G., 2014, "Labor Market Regulations: What Do We Know About Their Impacts in Developing Countries?" World Bank Research Observer 30, 124-153.

Blanchflower, D., and A. Oswald, 2005, "The Wage Curve Reloaded." IZA Discussion Paper, No. 1665 (Institute for the Study of Labor Economics).

Blundell, R., 1988, "Consumer Behavior: Theory and Evidence - A Survey." Economic Journal 98, 16-65.

Blundell, R., P. Pashardes, and G. Weber, 1993, "What We Learn about Consumer Demand Patterns from Micro Data?" American Economic Review 83, 570-597.

Bobonis. G., E. Miguel, and C. Puri-Sharma, 2006, "Iron Deficiency Anemia and School Participation." Journal of Human Resources 41, 692-721.

Bosch, M., and W. Maloney, 2007, "Comparative Analysis of Labor Market Dynamics Using Markov Processes: An Application to Informality." IZA Discussion Paper No. 3038 (Institute for the Study of Labor Economics).

Botelho, F., and V. Ponczek, 2011, "Segmentation in the Brazilian Labor Market." Economic Development and Cultural Change 59, 437-463.

Briceno-Garmendia, C., K. Smits, and V. Foster, 2008, "Financing Public Infrastructure in Sub-Saharan Africa: Patterns and Emerging Issues." AICD Background Paper 15 (World Bank).

Briceno-Garmendia, C., and V. Foster, 2010, Africa's Infrastructure: A Time for Transformation (World Bank).

Bryan, G., S. Chowdhury, and A. Mobarak, 2012, "Seasonal Migration and Risk Aversion." Centre for Economic Policy Research (London).

Bucheli, M., and C. Gonzalez, 2007, "An Estimation of the Wage Curve for Uruguay." Documentos de Trabajo No. 11-07, Universidad de la Republica.

Buffie, E., A. Berg, C. Pattillo, R. Portillo, and L. -F. Zanna, 2012, "Public Investment, Growth, and Debt Sustainability: Putting Together the Pieces." IMF Working Paper, No.12/144 (International Monetary Fund).

Burger, C., and S. Schotte, 2017, "A Structural Approach to Modelling Employment Transitioning in South Africa." Mimeo. (University of Stellenbusch; University of Gottingen and German Institute of Global and Area Studies, Institute of African Affairs.)

Calderon, C., E. Moral-Benito, and L. Serven, 2015, "Is Infrastructure Capital Productive? A Dynamic Heterogeneous Approach." Journal of Applied Econometrics 30, 177-198.

CInternational Monetary Fund. Not for Redistribution 
Calderon, C., and L. Serven, 2003, "The Output Cost of Latin America's Infrastructure Gap." In, W. Easterly and L. Serven, eds., The Limits of Stabilization: Infrastructure, Public Deficits, and Growth in Latin America (Stanford University Press and The World Bank).

Carneiro, F., and A. Henley, 2001, "Modelling Formal vs. Informal Employment and Earnings: MicroEconometric Evidence for Brazil.” Research Paper 2001-15 (Ysgol Rheolaeth a School of Management and Business, University of Wales).

Caselli, F., 2005, "Accounting for Cross-Country Income Differences." In, P. Aghion and S. Durlauf, eds., Handbook of Economic Growth, vol. 1 (Elsevier).

Castro Lugo, D., 2006, "Curva Salarial: Una Aplicaction Para El Caso de Mexico, 1993-2002." Estudios Economicos 21, 233-273.

Chang, C., Z. Liu, and M. Spiegel, 2013, "Capital Controls and Optimal Chinese Monetary Policy." Working Paper No. 2012-13, Federal Reserve Bank of San Francisco.

Chen, C., 2017, "Untitled Land, Occupational Choice, and Agricultural Productivity." American Economic Journal of Macroeconomics 9, 91-21.

Chirinko, R., 1993, "Business Fixed Investment Spending: Modeling Strategies, Empirical Results, and Policy Implications." Journal of Economic Literature 31, 1875-1911.

Christiaensen, L., and Y. Todo, 2014, "Poverty Reduction During the Rural-Urban Transformation — The Role of the Missing Middle." World Development 63, 43-58.

Christensen, B., and J. Schanz, 2018, "Central Banks and Debt: Emerging Risks to the Effectiveness of Monetary Policy in Africa." BIS Papers No. 99.

Colclough, C., G. Kingdon, and H. Patrinos, 2010, "The Changing Pattern of wage Returns to Education and Its Implications." Development Policy Review 28, 733-747.

Collard, F., and D. de la Croix, 2000, "Gift Exchange and the Business Cycle: The Fair Wage Strikes Back." Review of Economic Dynamics 3, 166-193.

Dalgaard, C., and H. Hansen, 2005, "The Return to Foreign Aid." Discussion Paper No.05-04, Institute of Economics, University of Copenhagen.

Danthine, J., and A. Kurmann, 2004, "Fair Wages in a New Keynesian Model of the Business Cycle." Review of Economic Dynamics 7, 107-142.

Danthine, J., and A. Kurmann, 2010, "The Business Cycle Implications of Reciprocity in Labor Relations." Journal of Monetary Economics 57, 837-850.

Deaton, A., and D. Muellbauer, 1980, Economics and Consumer Behavior (Cambridge University Press).

De Brauw, A., V. Mueller, and H. Lee, 2014, "The Role of Rural-Urban Migration in the Structural Transformation of Sub-Saharan Africa." World Development 63, 33-42.

De Gregorio, J., S. Edwards, and R. Valdes, 2000, "Controls on Capital Inflows: Do They Work?" Journal of Development Economics 63, 59-83. 
Devereux, S., 2005, "Can Minimum Wages Contribute to Poverty Reduction in Poor Countries?" Journal of International Development 17, 899-912.

Diao, X., J. Kseka, and M. McMillan, 2018, "Small Firms, Structural Change and Labor Productivity Growth in Africa." World Development 105, 400-415.

Diagne, A., and B. Diene, 2011, "Estimating Returns to Higher Education: A Survey of Models, Methods and Empirical Evidence." Journal of African Economies 20, iii80-iii132.

Djido, A., and B. Shiferaw, 2018, "Patterns of Labor Productivity and Income Diversification — Empirical Evidence from Uganda and Nigeria." World Development 105, 416-427.

Doss, C., C. Kovarik, A. Peterman, A. Quisumbing, and M. van den Bold, 2015, "Gender Inequalities in Ownership and Control of Land in Africa: Myth and Reality." Agricultural Economics 46, 403-434.

Eberly, J., S. Rebelo, and N. Vincent, 2008, "Investment and Value: A Neoclassical Benchmark." NBER Working Paper No. 13866 (National Bureau of Economic Research).

Ehrenreich, B., 2001, Nickled and Dimed (Picador).

Escribano, A., J. Guasch, and J. Pena, 2008, "Impact of Infrastructure Constraints on Firm Productivity in Africa." AICD Working Paper No. 9 (World Bank).

Fafchamps, M. and M. Soderbom, 2006, "Wages and Labor Management in African Manufacturing." Journal of Human Resources 41, 346-379.

Falco, P., A. Kerr, N. Rankin, J. Sandefur, and F. Teal, 2011, "The Returns to Formality and Informality in Urban Africa. Labour Economics 18 (Supplement 1), S23-S31.

Fedelino, A., and A. Kudina, 2003, "Fiscal Sustainability in African HIPC Countries: A Policy Dilemma?" IMF Working Paper No. 03/187 (International Monetary Fund).

Feldstein, M., 1964, "The Social Time Preference Discount Rate in Cost Benefit Analysis." Economic Journal $74,360-379$.

Fields, G., 2011a, "Labor Market Analysis for Developing Countries." Labour Economics 18, S16-S22.

Fields, G., 2011b, Working Hard, Working Poor: A Global Journey (Oxford University Press).

Foster, V., and C. Briceno-Garmendia, 2010, Africa's Infrastructure: A Time for Transformation (Agence Francaise de Developpement and the World Bank).

Fox, L., 2013, "Africa's Got Work to Do: Employment Prospects in the New Century." IMF Working Paper No. 13/201 (International Monetary Fund).

Fox, L., 2015, "Are African Households Heterogeneous Agents? Stylized Facts in Pattterns of Consumption, Employment, Income and Earnings for Macroeconomic Modelers." IMF Working Paper No. 15/102 (International Monetary Fund).

Fuglie, K., 2010, "Total Factor Productivity in the Global Agricultural Economy: Evidence from FAO Data." In, J. Alston, B. Babcock, and P. Pardey, eds., The Shifting Patterns of Agricultural Production and Productivity Worldwide (Iowa State University Press).

CInternational Monetary Fund. Not for Redistribution 
Funkhouser, E., 1997a, "Demand-Side and Supply-Side Explanations for Barriers to Labor Market Mobility in Developing Countries: The Case of Guatemala." Economic Development and Cultural Change, 45, 341-366.

Funkhouser, E., 1997b, "Mobility and Labor Market Segmentation: The Urban Labor Market in El Salvador." Economic Development and Cultural Change 46, 123-153.

Funkhouser, E., 1998, "The Importance of Firm Wage Differentials in Explaining Hourly Earnings Variation in the Large-Scale Sector of Guatemala." Journal of Development Economics 55, 115-131.

Galiani, S., 1999, "Wage Determination in Argentina: An Econometric Analysis With Methodology Discussion." Mimeo (Wolfson College, University of Oxford and Instituto Torcuato Di Tella).

Galindo, L., and H. Catalan, 2010, "El Mercado Laboral en Mexico: Una Curva de Salarios?" Comercio0 Exterior 60, 221-272.

Garcia, P., and P. Granados, 2005, "La Curva de Salarios en Chile." Working Paper No. 320 (Central Bank of Chile).

Gindling, T., 2014, "Does Increasing the Minimum Wage Reduce Poverty in Developing Countries?" IZA World of Labor 30, 1-10.

Glinskaya, E., and M. Lokshin, 2005, "Wage Differentials Between the Public and Private Sectors." World Bank Policy Research Working Paper No. 3574.

Goldberg, P., and N. Pavcnik, 2003, "The Response of the Informal Sector to Trade Liberalization." Journal of Development Economics 72, 463-496.

Gollin, D., D. Lagakos, and M. Waugh, 2014, "The Agricultural Productivity Gap." Quarterly Journal of Economics 129, 939-993.

Gollin, D., and R. Rogerson, 2011, "Agricultural Development and Structural Transformation in a Closed Economy: Evidence From Uganda." Presented at the World Bank ABCDE Conference (Paris).

Gong, X., and A. van Soest, 2002, "Wage Differentials and Labor Mobility in the Urban Labor Market: A Panel Data Analysis for Mexico." Labor Economics 9, 513-529.

Gottlieb, C., and J. Grobovsek, 2019, "Communal Land and Agricultural Productivity." Journal of Development Economics 138, 135-152.

Gunther, I., and A. Launov, 2012, "Informal Employment in Developing Countries: Opportunity or Last Resort?" Journal of Development Economics 97, 88-98.

Gurara, D., G. Melina, and L. -F. Zanna, 2019, "Some Policy Lessons from Country Applications of the DIG and DIGNAR Models." IMF working Paper No. 19/62 (International Monetary Fund).

Harati, R., 2013, "Heterogeneity in the Egyptian Informal Labor Market: Choice or Obligation?" CES Working Paper No. 2013.32 (University of Paris).

Hayashi, F., and T. Inoue, 1991, "The Relation Between Firm Growth and Q With Multiple Capital Goods: Theory and Evidence from Panel Data on Japanese Firms." Econometrica 59, 731-753.

Heggie, I., and P. Vickers, 1998, "Commercial Management and Financing of Roads." World Bank Technical Paper 409. 
Heintz, J., and F. Slonimczyk, 2007, "Beyond Dualism: Multisegmented Labor Markets in Ghana." Economics Department Working Paper Series, Paper 35 (University of Massachusetts).

Heintz, J., and D. Posel, 2008, "Revisiting Informal Employment and Segmentation in the South African Labour Market." South African Journal of Economics 76, 26-44.

HM Treasury, 2018, The Green Book: Central Government Guidance on Appraisal and Evaluation. The Stationary Office (London).

Hoddinot, J., 1996, "Wages and Unemployment in an Urban African Labour Market." Economic Journal 106, 1610-1626.

Hulten, C., 1996, "Infrastructure Capital and Economic Growth: How Well You Use It May Be More Important Than How Much You Have." NBER Working Paper, No. 5847.

Hulten, C., E. Bennathan, and S. Srinivasan, 2006, "Infrastructure, Externalities, and Economic Development: A Study of Indian Manufacturing." World Bank Economic Review 20(2), 291-308

Ilkkaracan, I., and R. Selim, 2003, "The Role of Unemployment in Wage Determination: Further Evidence on the Wage Curve from Turkey." Applied Economics 35, 1589-1598.

International Monetary Fund, 2007, "Regional Economic Outlook: Sub-Saharan Africa." April (International Monetary Fund).

International Monetary Fund, 2017, "Guidance Note on the Bank-Fund Debt Sustainability Framework for Low Income Countries" (International Monetary Fund).

International Monetary Fund, 2018, Macroeconomic Developments and Prospects in Low-Income Countries 2018." IMF Policy Paper (International Monetary Fund).

International Monetary Fund, 2020, "Guidance Note on the Bank-Fund Debt Sustainability Framework for Low Income Countries" (International Monetary Fund).

Isham, J., and D. Kaufmann, 1999, "The Forgotten Rationale for Policy Reform: The Productivity of Investment Projects." Quarterly Journal of Economics 114, 149-184.

Issoufou, S., E. Buffie, M. Bamba Diop, and K. Thiaw, 2014. "Efficient Energy Investment and Fiscal Adjustment in Senegal." IMF Working Paper No. 14/44 (International Monetary Fund).

Italian Centre for International Development, 2018, "The Employment Situation in The Gambia." Mimeo.

Ivanchovichina, E., Estache, A., Foucart, R., Garsous, G., and T. Yepes, 2013, "Job Creation Through Infrastructure Investment in the Middle East and North Africa." World Development 45, 209-222.

Jaffrey, S., Y. Ghulam, and V. Shah, Winter 2006, "Inter-Industry Wage Differentials in Pakistan." Pakistan Development Review 45, 925-946.

Joumard, I., and J. Velez, 2013, "Income Inequality an Poverty in Colombia, Part 1: The Role of the Labor Market." OECD Economics Department Working Paper No. 1036.

Kim, J., Kwak, J., and K. Lee, 2015, "Estimating Tobin's Q for Listed Firms in Korea (1980-2005): Comparing Alternative Approaches and an Experiment with Investment Functions." Seoul Journal of Economics 28, $1-26$. 
Kingdon, G., and J. Knight, 1999, "Unemployment and Wages in South Africa: A Spatial Approach." Mimeo. (Institute of Economics and Statistics, Oxford)

Kingdon, G., and J. Knight, 2004, "Unemployment in South Africa: The Nature of the Beast." World Development 32, 391-408.

Kingdon, G., J. Sandefur, and F. Teal, 2005, "Labor Market Flexibility, Wages and Incomes in Sub-Saharan Africa in the 1990s." Global Poverty Research Group Working Paper No. 030.

Kong, M., 2002, "Stock Market Development, Liquidity Constraint and Investment: A Case of Korean Jaebol and Non-Jaebol Manufacturing Firms in the 1980s." Asian Economic Journal 12, 1-22.

Krueger, A., and L. Summers, 1987, "Reflections on the Inter-Industry Wage Structure." In, K. Lang and J. Leonard, eds., Unemployment and the Structure of Labor Markets (Basil Blackwell).

Krueger A., and L. Summers, 1988, "Efficiency Wages and the Inter-Industry Wage Structure." Econometrica $56,259-293$.

Lachaud, J., 1995, "Public-Private Wage Differentials in French-Speaking Africa: A Comparative Analysis." Labour 9, 295-341.

Lagakos, D., and M. Waugh, 2013, "Selection, Agriculture, and Cross-Country Productivity Differences." American Economic Review 103, 948-980.

La Porta, R., and A. Shleifer, 2008, "The Unofficial Economy and Economic Development." Brookings Papers on Economic Activity, Fall, 275-352.

La Porta, R. and A. Shleifer, 2014, "Informality and Development." Journal of Economic Perspectives 28 (Summer), 109-126.

Levy, S., 2008, Good Intentions, Bad Outcomes: Social Policy, Informality, and Economic Growth in Mexico (Brookings Institution; Washington, D.C.).

Lluch, C., A. Powell, and R. Williams, 1977, Patterns in Household Demand and Saving (Oxford University Press).

Lopez Machuca, J., and J. Mendoza Cota, 2017, "Wage, Unemployment, and Labor Productivity in Mexican Manufacturing Industry." Ensayos Revista de Economia 36, 185-228.

Ljubaj, I., A. Martinis, and M. Mrkalj, 2010, "Capital Inflows and Efficiency of Sterilisation - Estimation of Sterilisation and Offset Coefficients." Mimeo (Croatian National Bank).

Lucas, R., 1981, "Unemployment Policy." In, R. Lucas, ed., Studies in Business Cycle Theory (MIT Press).

MacIsaac, D.,, and M. Rama, 1997, "Determinants of Hourly Earnings in Ecuador: The Role of Labor Market Regulations." Journal of Labor Economics 15, 136-165.

Maloney, W., and E. Ribeiro, 1999, "Efficiency Wage and Union Effects in Labor Demand and Wage Structure in Mexico: An Application of Quantile Analysis." Mimeo.

Maloney, W., 1999, "Does Informality Imply Segmentation in Urban Labor Markets? Evidence From Sectoral Transitions in Mexico.” World Bank Economic Review 13, 275-302.

CInternational Monetary Fund. Not for Redistribution 
Maloney, W., 2002, "Distortion and Protection in the Mexican Labor Market." Mimeo (World Bank).

Maloney, W., 2004, "Informality Revisited.” World Development 32, 1159-1178.

Manda, D., 2002, "Wage Determination in Kenyan Manufacturing." In, A. Bigsten and P. Kimuyu, eds., Structure and Performance of Manufacturing in Kenya (Palgrave).

Marcelle, M., and E. Strobl, 2003, "Do Smaller Firms Pay Less in the Caribbean? The Case of Trinidad and Tobago." Journal of Development Studies 39, 181-198.

Marshall, K., 2012, "Factor Payment Shares in a Large Cross-Section of Countries." Mimeo (California Polytechnic State University).

Marto, R., C. Papageorgiou, and V. Klyuev, 2018, "Building Resilience to Natural Disasters: An Application to Small Developing States," Journal of Development Economics 135, 574-586.

McCaig, B., and N. Pavcnik, 2013, "Moving Out of Agriculture: Structural Change in Vietnam." NBER Working Paper No. 19616.

McCullough, E., 2017, "Labor Productivity and Employment Gaps in Sub-Saharan Africa." Food Policy 67, 133-152.

McMillan, M., and D. Heady, 2014, "Introduction - Understanding Structural Transformation in Africa." World Development 63, 1-10.

Melina, G., S. C. Yang, and L. -F. Zanna, 2016, Debt Sustainability, Public Investment, and Natural Resources in Developing Countries: The DIGNAR Model," Economic Modelling 52, 630-649.

Miguel, E., and M. Kremer, 2004, "Worms: Identifying Impacts on Education and Health in the Presence of Treatment Externalities." Econometrica 72, 159-217.

Mizala, A., and P. Romaguera, 1998, "Wage Differentials and Occupational Wage Premia: Firm-Level Evidence for Brazil and Chile." Review of Income and Wealth 44, 239-257.

Montenegro, C., and H. Patrinos, 2014, "Comparable Estimates of Returns to Schooling Around the World." Policy Research Working Paper No. 7020 (World Bank).

Mudiriza, G., and L. Edwards, 2018, "Can the New Economic Geography Explain Regional Wage Disparities in South Africa?" Mimeo (University of Capetown, South Africa).

Musgrave, J., 1992, "Fixed Reproducible Wealth in the United States, Revised Estimates." Survey of Current Business 72 (January), 106-137.

Nadiri, M., and I. Prucha, 1996, "Estimation of the Depreciation Rate of Physical and R\&D Capital in the U.S. Total Manufacturing Sector." Economic Inquiry 34, 43-56.

Nattrass, N., and R. Walker, 2005, "Unemployment and Reservation Wages in Working-Class Cape Town." South African Journal of Economics 73, 498-509.

Ndulu, B., 2006, "Infrastructure, Regional Integration and Growth in Sub-Saharan Africa: Dealing with the Disadvantages of Geography and Sovereign Fragmentation." Journal of African Economies 15 (AERC Supplement 2), 212-244.

CInternational Monetary Fund. Not for Redistribution 
Neri, M., 2002, "Decent Work and the Informal Sector in Brazil." Ensaios Economicos No. 461 (Fundacao Getulio Vargas).

OECD, 2009, Is Informal Normal? Towards More and Better Jobs in Developing Countries (Organization for Economic Develpment and Cooperation).

Ogaki, M., J. Ostry, and C. Reinhart, 1996, "Saving Behavior in Low- and Middle-Income Developing Countries." IMF Staff Papers 43, 38-71.

Otsuka, K., and F. Place, 2001, Land Tenure and Natural Resource Management: A Comparative Study of Agrarian Communities in Asia and Africa (International Food Policy Research Institute).

Otsuka, K., 2007, "Efficiency and Equity Effects of Land Markets." In, R. Evenson, and P. Pingali, eds., Handbook of Agricultural Economics, vol. 3 (North-Holland).

Park, S., and D. Shin, 2008, "New Evidence on the Korean Wage Curve." Applied Economics Letters 15, 221-224.

Peet, E., G. Fink, and W. Fawzi, 2015, "Returns to Education in Developing Countries: Evidence From the Living Standards and Measurement Study Surveys." Economcs of Education Review 49, 69-90.

Pereira, A., and P. Ferreira, 2007, "Efeitos de Crescimento e Bemestar da Lei de Parceria Publico-Privada no Brasil." Mimeo (EPGE-Getulio Vargas Foundation).

Perrault, J., L. Savard, and A. Estache, 2010, "The Impact of Infrastructure Spending in Sub-Saharan Africa: A CGE Modeling Approach." Policy Research Working Paper, No. 5386 (World Bank).

Perry, G., Maloney, W., and O. Arias, 2007, "Informality: Exit and Exclusion.” Mimeo (World Bank).

Pinto, B., 2018, "The Distressing Debt Sustainability Framework of the IMF and World Bank" (Brookings Institute).

Pradhan, M., and A. van Soest, 1995, "Formal and Informal Sector Employment in Urban Areas of Bolivia." Labour Economics 2, 275-297.

Pratap, S., and E. Quintin, 2006, "Are Labor Markets Segmented in Developing Countries? A Semi-Parametric Approach.” European Economic Review 50, 1817-1841.

Presbitero, A., 2016, "Too Much and Too Fast? Public Investment Scaling-Up and Absorptive Capacity." Journal of Development Economics 120, 17-31.

Pritchett, L., 2000, "The Tyranny of Concepts: CUDIE (Cumulated, Depreciated, Investment Effort) is Not Capital." Journal of Economic Growth 5, 361-384.

Pritchett, L., 2001, "Where Has All the Education Gone?", The World Bank Economic Review, 15(3), 367-391.

Psacharopoulos, G. and H. Patrinos, 2004, "Returns to Investment in Education: A Further Update." Education Economics 12, 111-134.

Ramos, R., Duque, J., and J. Surinach, 2010, "Is the Wage Curve Formal or Informal? Evidence for Colombia." Economics Letters 109, 63-65.

CInternational Monetary Fund. Not for Redistribution 
Rand, J., and N. Torm, 2012, "The Informal Wage Gap Among Vietnamese Micro Firms." Journal of the Asia Pacific Economy 17, 560-577.

Restuccia, D., D. Yang, and X. Zhu, 2008, "Agriculture and Aggregate Productivity: A Quantitative CrossCountry Analysis." Journal of Monetary Economics 55, 234-250.

Restuccia, D., and R. Santaeulalia-Lopis, 2017, "Land Misallocation and Productivity." NBER Working Paper No. 23128 (National Bureau of Economic Research).

Sahoo, P., and R. Dash, 2012, "Economic Growth in South Asia: Role of Infrastructure." Journal of International Trade and Economic Development, 217-252.

Schaffner, J., 1999, "Premiums to Employment in Larger Establishments: Evidence from Peru." Journal of Development Economics 55, 81-113.

Schaller, H., 1990, "A Re-Examination of the Q Theory of Investment Using U.S. Firm Data." Journal of Applied Econometrics 5, 309-325.

Schultz, P., 2004, "Evidence of Returns to Schooling in Africa From Household Surveys: Monitoring and Restructuring the Market for Education." Journal of African Economies 13/2, ii95-ii148.

Sen, A., 1967, "Isolation, Assurance and the Social Rate of Discount." Quarterly Journal of Economics 81, 112-124.

Shafik, N., 1992, "Modeling Investment Behavior in Developing Countries: An Application to Egypt." Policy Research Working Paper No. 452 (World Bank).

Shapiro, M., 1986, "The Dynamic Demand for Capital and Labor." Quarterly Journal of Economics 101, 513542.

Shapiro, C., and J. Stiglitz, 1984, "Equilibrium Unemployment as a Worker Discipline Device." American Economic Review 74, 433-444.

Soderbom, M., and F. Teal, 2004, "Size and Efficiency in African Manufacturing Firms: Evidence from FirmLevel Panel Data." Journal of Development Economics 73, 369-394.

Soderbom, M., F. Teal, and A. Wambugu, 2005, "Unobserved Heterogeneity and the Relation Between Earnings and firm Size: Evidence from Two Developing Countries." Economics Letters 87, 153-159.

Strobl, E., and R. Thornton, 2004, "Do Large Employers Pay More? The Case of Five Developing African Countries." Journal of Economic Development 29, 137-161.

Tansel, A., and E. Acar, 2012, "The Formal/Informal Employment Earnings Gap: Evidence from Turkey." IZA Discussion Paper No. 6556 (Institute for the Study of Labor).

Tansel, A., H. Keskin, and Z. Ozdemir, 2015, "Is There an Informal Employment Wage Penalty in Egypt?" Turkish Economic Association Discussion Paper No. 2015/14.

Teal, F., 2011, "The Price of Labour and Understanding the Causes of Poverty." Labour Economics 18, S17-S15.

Teal, F., 2017, "What Constrains the Demand for Labour in Firms in Sub-Saharan Africa? Some Evidence from Ghana." Mimeo. 
Thomas, M., and L. Vallee, 1996, "Labor Market Segmentation in Cameroonian Manufacturing." Journal of Development Studies 32, 876-898.

Thurlow, J., and P. Wobst, 2004, "The Road to Pro-Poor Growth in Zambia: Past Lessons and Future Challenges." DSGD Discussion Paper No. 16 (International Food Policy Research Center).

Turnham, D., 1993, Employment and Development: A New Review of the Evidence (Organization for Economic Cooperation and Development).

Udall, A., and S. Sinclair, 1982, "The 'Luxury Unemployment' Hypothesis: A Review of Recent Evidence." World Development 10, 49-62.

Ulyssea, 2010, "Regulation of Entry, Labor Market Institutions and the Informal Sector." Journal of Development Economics 91, 87-99.

United States Department of Agriculture, 2018, "Agricultural Total Factor Productivity Growth Indices for Individual Countries" (data set).

von Fintel, D., 2015, "Wage Flexibility in a High Unemployment Regime: Spatial Heterogeneity and the Size of Local Labour Markets." REDI3x3 Working Paper 8 (Research Project on Employment, Income Distribution and Inclusive Growth, University of Capetown).

Velenchik, A., 1997, "Government Intervention, Efficiency Wages, and the Employer Size Wage Effect in Zimbabwe." Journal of Development Economics 53, 305-338.

Wichern, R., U. Hausner, and D. Chiwele, 1999, "Impediments to Agricultural Growth in Zambia." TMD Discussion Paper No. 47 (International Food Policy Research Center).

World Bank, 2017, "The Gambia: Education Sector Public Expenditure Review." Report No. ACS23503 (World Bank).

Wu, Z., 2004, "Wage Curve for Urban China: A Panel Data Approach." Applied Economics Letters 11, 425-428.

Yepes, T., 2010, "Expenditure on Infrastructure in East Asia Region, 2006-2010." Paper commissioned for the ADB-JBIC-World Bank East Asia Pacific Infrastructure Flagship Study.

Young, A., 2013, "Inequality, the Urban-Rural Wage Gap, and Migration." Quarterly Journal of Economics $128,1727-1785$.

Zanna, L. -F., E. Buffie, R. Portillo, A. Berg, and C. Pattillo, 2019, "Borrowing for Growth: Big Pushes and Debt Sustainability in Low-Income Countries." World Bank Economic Review 33, 661-689.

CInternational Monetary Fund. Not for Redistribution 


\section{TABLES}

Table 1. The DIG-Labor Suite of Models: Alternative Specifications

\begin{tabular}{|c|c|c|c|}
\hline \multirow[t]{3}{*}{ DIG } & \multicolumn{3}{|c|}{$\begin{array}{l}\text { Two sectors, with integrated labor market, full wage flexibility and full } \\
\text { employment. No open unemployment or under-employment }\end{array}$} \\
\hline & \multicolumn{3}{|c|}{ Sector } \\
\hline & Formal & Agriculture & Non-Agricultural Informal \\
\hline $\begin{array}{l}\text { DIG-Labor 1: } \\
\text { Involuntary } \\
\text { unemployment in } \\
\text { formal sector only. }\end{array}$ & $\begin{array}{l}\text { EW } \rightarrow \text { open } \\
\text { unemployment. }\end{array}$ & $\begin{array}{l}\text { Flex-wage, with labor paid its } \\
\text { marginal value product plus a } \\
\text { share of land rents. }\end{array}$ & $\begin{array}{l}\text { Own account workers. Wage } \\
\text { equals what labor earns in } \\
\text { agriculture. }\end{array}$ \\
\hline $\begin{array}{l}\text { DIG-Labor 2: } \\
\text { Involuntary } \\
\text { unemployment in } \\
\text { entire non- } \\
\text { agricultural sector. }\end{array}$ & $\begin{array}{l}\text { EW } \rightarrow \text { open } \\
\text { unemployment. }\end{array}$ & $\begin{array}{l}\text { Flex-wage, with labor paid its } \\
\text { marginal value product plus a } \\
\text { share of land rents. }\end{array}$ & $\begin{array}{l}\text { Wage employees. Firms pay } \\
\text { an EW below formal sector } \\
\text { wage } \rightarrow \text { open unemployment. } \\
\text { Wage exceeds earnings of } \\
\text { labor in agriculture. }\end{array}$ \\
\hline DIG-Labor 3 & $\begin{array}{l}\text { EW, no open } \\
\text { unemployment. }\end{array}$ & $\begin{array}{l}\text { Flex-wage, with labor } \\
\text { receiving marginal value } \\
\text { product plus a share of land } \\
\text { rents. }\end{array}$ & $\begin{array}{l}\text { Own account workers. Wage } \\
\text { equals what labor earns in } \\
\text { agriculture. }\end{array}$ \\
\hline $\begin{array}{l}\text { All DIG-Labor } \\
\text { variants }\end{array}$ & \multicolumn{3}{|c|}{$\begin{array}{l}\text { Underemployment. For any given unemployment rate (even zero in DIG-Labor 3), } \\
\text { aggregate labour productivity rises if labor moves from informal to formal sector } \\
\text { or from agriculture to non-agriculture. }\end{array}$} \\
\hline
\end{tabular}

Notes: EW refers to Efficiency Wages. 
Table 2. Unemployment Rates in Less-Developed Countries.

\begin{tabular}{|c|c|c|c|c|}
\hline Country & Year & National & Rural & Urban \\
\hline Algeria & 2013 & 9.8 & 8.1 & 10.6 \\
\hline Bahamas & 2013 & 15.8 & - & $15.8^{\mathrm{a}}$ \\
\hline Bangladesh & 2010 & 4.5 & 4.0 & 6.5 \\
\hline Belize & 2013 & $11.7^{\mathrm{d}}$ & 11.8 & 11.5 \\
\hline Botswana & 2010 & 17.9 & - & $9.8^{\mathrm{b}}$ \\
\hline Brazil & 2009 & $8.4^{\mathrm{d}}$ & 3.4 & 9.3 \\
\hline Cameroon & 2010 & 3.8 & 1.4 & 8.1 \\
\hline Colombia & 2014 & 9.1 & 5.7 & 10.0 \\
\hline Costa Rica & 2014Q2 & $8.6^{\mathrm{d}}$ & 8.8 & 8.5 \\
\hline Cyprus & 2014 & 16.1 & 17.1 & 15.7 \\
\hline Cote d'Ivoire & 2015 & $6.9^{\mathrm{e}}$ & 3.0 & $13.4,7.7^{\mathrm{c}}$ \\
\hline Dominican Rep. & 2013 & $15.0^{\mathrm{d}}$ & 14.2 & 15.4 \\
\hline Egypt & 2013 & 13.2 & 10.7 & 16.5 \\
\hline Gabon & 2010 & 20.4 & 19.0 & 21.0 \\
\hline Gambia & 2012 & 29.8 & 31.1 & 28.4 \\
\hline Guyana & 2002 & - & - & $11.8^{\mathrm{b}}$ \\
\hline India & 2014 & $4.9^{\mathrm{d}}$ & 5.5 & 4.7 \\
\hline Indonesia & 2012 & $6.1^{\mathrm{f}}$ & 4.7 & 7.7 \\
\hline Iran & 2013 & 10.4 & 7.0 & 11.8 \\
\hline Jamaica & 2013 & 15.2 & - & - \\
\hline Jordon & 2012 & 12.2 & 14.2 & 11.8 \\
\hline Kyrgyzstan & 2012 & $8.4^{\mathrm{f}}$ & 7.9 & 9.5 \\
\hline Malawi & 2013 & 6.6 & 6.0 & 11.5 \\
\hline Malaysia & 2014 & 2.9 & 3.2 & 3.1 \\
\hline Mauritania & 2012 & 10.1 & - & - \\
\hline Mauritius & 2014 & 7.8 & - & - \\
\hline Mexico & 2014 & 4.8 & 2.8 & 5.3 \\
\hline Morocco & 2014 & 9.7 & 4.2 & 15.0 \\
\hline Mozambique & 2012 & $22.6^{\mathrm{d}}$ & - & - \\
\hline Namibia & 2014 & $28.1^{\mathrm{e}}$ & 30.2 & 26.2 \\
\hline Nigeria & 2015Q3 & $9.9^{\mathrm{d}, \mathrm{f}}$ & 9.0 & 12.1 \\
\hline Philippines & 2014 & 6.8 & - & $9.3^{\mathrm{b}}$ \\
\hline Senegal & 2015 & $13.4^{\mathrm{g}}$ & 10.1 & 17.2 \\
\hline South Africa & 2012 & 24.7 & 28.0 & 24.3 \\
\hline Tajikistan & 2009 & 11.5 & 9.6 & 16.8 \\
\hline Thailand & 2015 & .9 & 1.0 & .9 \\
\hline Tunisia & 2012Q4 & $16.7^{\mathrm{f}}$ & - & $20.4^{\mathrm{b}}$ \\
\hline Turkey & 2013 & 9.7 & 6.1 & 11.5 \\
\hline Uruguay & 2014 & 6.6 & 4.7 & $6.7,7.0^{\mathrm{c}}$ \\
\hline Zambia & 2012 & 7.8 & 3.3 & 14.2 \\
\hline
\end{tabular}

Sources: International Labor Office, World Economic Outlook, World Bank, CIA World Factbook, and National Statistical Offices (Labor Force Surveys, Censuses, Poverty Surveys, AIDS Surveys, and Household Surveys). Unless otherwise noted, figures for the national unemployment rate are based on two sources that agree to within one percentage point.

${ }^{a}$ Unemployment rate for New Providence Island (where the capital city is located).

${ }^{\mathrm{b}}$ Unemployment rate for the capital city.

${ }^{c}$ Unemployment rates in the capital city and other urban centers, respectively.

${ }^{\mathrm{d}}$ Disagreement between two or more sources.

e Only one source (Labor Force Survey for Cote d'Ivoire and Namibia; Population Census for Guyana).

${ }^{\mathrm{f}}$ Data cross-checked for a different year.

g Unemployment rate changed more than $10 \%$ across two years in the Labor Force Survey and the Census. 
Table 3. Calibration of the Model.

\begin{tabular}{|c|c|}
\hline Parameter/Variable & Value in Base Case \\
\hline $\begin{array}{l}\text { Consumption shares of the imported consumer } \\
\text { good and the formal and informal goods }\left(\gamma_{m}, \gamma_{n}, \gamma_{j}\right)\end{array}$ & $\begin{array}{c}\gamma_{n}=0.40, \gamma_{m}=0.10, \gamma_{j}=0.20 \\
\gamma_{x}=1-\gamma_{n}-\gamma_{m}-\gamma_{j}=0.30\end{array}$ \\
\hline Intertemporal elasticity of substitution $(\tau)$ & 0.40 \\
\hline $\begin{array}{l}\text { Elasticity of substitution between } \\
\text { good } x \text { and goods } n, j \text {, and } m\left(\varepsilon_{1}\right)\end{array}$ & 0.5 \\
\hline $\begin{array}{l}\text { Elasticity of substitution between the } \\
\text { formal and informal traded goods }\left(\varepsilon_{2}\right)\end{array}$ & 0.5 \\
\hline $\begin{array}{l}\text { Elasticity of substitution between the imported } \\
\text { consumer good and the formal good }\left(\varepsilon_{3}\right)\end{array}$ & $0.5(5)$ \\
\hline Wages in the formal and informal sectors $\left(w_{s}, w_{n}, w_{j}\right)$ & $w_{s}=3, w_{n}=1, w_{j}=0.6$ \\
\hline Factor shares in the formal sector $\left(\alpha_{n}, \theta_{n}\right)$ & $\alpha_{n}=0.50, \theta_{n}=0.30$ \\
\hline Factor shares in the informal sector $\left(\alpha_{j}, \theta_{j}\right)$ & $\alpha_{j}=0.20, \theta_{j}=0.20$ \\
\hline Factor shares in agriculture $\left(\chi, \alpha_{x}, \theta_{x}\right)$ & $\chi=0.30, \alpha_{x}=0.20, \theta_{x}=0.05$ \\
\hline Depreciation rates $\left(\delta, \delta_{z}, \delta_{b}, \delta_{u}\right)$ & $\delta=\delta_{z}=\delta_{b}=\delta_{u}=0.05$ \\
\hline Real interest rate on concessional loans $\left(r_{d}\right)$ & 0.013 \\
\hline Real interest rate on external commercial debt $\left(r_{d c}\right)$ & 0.06 \\
\hline Trend growth rate $(g)$ & 0.023 \\
\hline Ratio of user fees to recurrent costs $(f)$ & 0.5 \\
\hline Consumption VAT rates $\left(h, g_{j}, g_{x}\right)^{1}$ & $h=0.20, g_{j}=0.30, g_{x}=0.10$ \\
\hline Taxes on profits, wages, and land rents $\left(f_{n}, f_{j}, f_{x}, f_{w}, f_{w j}, f_{w x}, f_{h}\right)$ & $\begin{array}{c}f_{n}=0.15, f_{j}=0.03, f_{x}=0.02 \\
f_{w}=0.12, f_{w j}=f_{w x}=f_{h}=0.01\end{array}$ \\
\hline Efficiency of public investment $(s)$ & 1 \\
\hline Absorptive capacity constraint $(\phi)$ & 0 \\
\hline Return on infrastructure $\left(R_{z}\right)$ & 0.20 \\
\hline Real interest rate on domestic bonds $(r)$ & 0.10 \\
\hline Real interest rate on foreign loans held by the private sector $\left(r_{f}\right)$ & 0.10 \\
\hline
\end{tabular}


Table 3 (Cont.)

\begin{tabular}{|c|c|}
\hline Parameter/Variable & Value in Base Case \\
\hline Interest elasticity of private capital flows $(\Gamma)$ & 1 \\
\hline Ratio of maintenance spending to GDP $\left(P_{z} m / G D P\right)$ & 0.01644 \\
\hline Ratio of infrastructure investment to GDP $\left(P_{z} i_{z} / G D P\right)$ & 0.06 \\
\hline Ratios of investment in education to GDP $\left(P_{s} i_{b} / G D P, P_{s} i_{u} / G D P\right)$ & $P_{s} i_{b} / G D P=0.028, P_{s} i_{u} / G D P=0.012$ \\
\hline Ratio of domestic public debt to GDP $(b / G D P)$ & 0.15 \\
\hline $\begin{array}{l}\text { Ratio of private foreign loans and concessional and non- } \\
\text { concessional public external debt }\left(b_{f}, d, d c\right) \text { to initial GDP }\end{array}$ & $\begin{array}{c}b_{f} / G D P=0, d / G D P=0.32 \\
d c / G D P=0.06\end{array}$ \\
\hline q-elasticity of investment spending $(\Omega)$ & 2.5 \\
\hline $\begin{array}{l}\text { Return on maintenance relative to new } \\
\text { investment in infrastructure }\left(R_{m z}\right)\end{array}$ & $R_{m z}=1$ \\
\hline $\begin{array}{l}\text { Share of new high-skill workers drawn from the pool of low-skill } \\
\text { workers in sector } x-j\left(\Delta_{x j}\right) \text { and the fraction of newly created/vacant } \\
\text { formal sector jobs filled by workers from sector } x-j(\xi)\end{array}$ & $\Delta_{x j}=0.80, \xi=0.5$ \\
\hline Unemployment rate $(u)$ & $u=0.06$ \\
\hline $\begin{array}{l}\text { Elasticity of the real wage in the formal sector with respect to the } \\
\text { unemployment rate }\left(g_{3}\right) \text { and the real informal sector wage }\left(g_{2}\right)\end{array}$ & $g_{2}=0.1, g_{3}=0.5$ \\
\hline $\begin{array}{l}\text { Cost shares of nontraded inputs in the production of capital goods } \\
\left(\alpha_{i j}, \alpha_{i n}, i=s, z, k\right)\end{array}$ & $\begin{aligned} \alpha_{k j}=\alpha_{z j} & =0.35, \alpha_{k n}=\alpha_{z n}=0.15 \\
\alpha_{s j} & =0.60, \alpha_{s n}=0.20\end{aligned}$ \\
\hline Returns to education $\left(R_{u}, R_{b}\right)^{2}$ & $R_{u}=0.30, R_{b}=0.30$ \\
\hline $\begin{array}{l}\text { Ratio of elasticities of sectoral output with respect } \\
\text { to the stock of infrastructure }\left(\psi_{n} / \psi_{x}, \psi_{j} / \psi_{x}\right)\end{array}$ & 1 \\
\hline $\begin{array}{l}\text { Long-run targets for domestic debt }\left(b^{\text {target }}\right) \text { and external commercial } \\
\text { debt }\left(d c^{\text {target }}\right)\end{array}$ & $\begin{array}{l}b^{\mathrm{target}}=b_{0} \\
d c^{\mathrm{target}}=d c_{0}\end{array}$ \\
\hline $\begin{array}{l}\text { Division of fiscal adjustment between } \\
\text { expenditure cuts and tax increases }(\lambda)\end{array}$ & 0.5 \\
\hline Residual financing of the fiscal gap $\left(\lambda_{d c}\right)$ & 0.30 \\
\hline
\end{tabular}

${ }^{1}$ Recall that the consumption VAT proxies for all indirect tax rates.

${ }^{2}$ For the assumed time lags, the internal rate of return is $12 \%$ for basic education and $10 \%$ for upper-level education. 
Table 4. Long-Run Effects of Increasing One Component of Public Investment. Increase of One Percent of Initial GDP. ${ }^{1}$

\begin{tabular}{|c|c|c|c|c|c|c|c|c|c|}
\hline \multicolumn{10}{|c|}{ (a) Infrastructure investment } \\
\hline Calibration & $G D P$ & $C / N N I$ & $k$ & $C I C$ & $q_{x}$ & $q_{n}$ & $q_{j}$ & $P_{n}$ & $P_{j}$ \\
\hline$\varepsilon_{3}=0.5$ & 4.6 & 3.8 & 3.9 & 0.52 & 4.6 & 4.8 & 4.6 & -2.3 & -0.2 \\
\hline \multirow[t]{2}{*}{$\varepsilon 3=5$} & 5.1 & 4.3 & 4.8 & 0.65 & 4.1 & 6.5 & 5.0 & -1.7 & 0.2 \\
\hline & $L_{n}$ & $L_{j}$ & $L_{x}$ & $u$ & $E A P G$ & $w_{n} / P$ & $w_{j} / P$ & $w_{s} / P$ & $\triangle T / G D P_{o}$ \\
\hline$\varepsilon 3=0.5$ & 0.6 & -0.1 & 0 & 6.0 & 5.5 & 2.8 & 5.5 & 4.3 & -0.35 \\
\hline$\varepsilon 3=5$ & 2.3 & 0.6 & -0.4 & 5.9 & 5.4 & 2.7 & 5.2 & 5.4 & -0.24 \\
\hline \multicolumn{10}{|c|}{ (b) Investment in basic education } \\
\hline Calibration & $G D P$ & $C / N N I$ & $k$ & CIC & $q_{x}$ & $q_{n}$ & $q_{j}$ & $P P_{n}$ & $P_{j}$ \\
\hline$\varepsilon_{3}=0.5$ & 10.1 & 10.3 & 10.6 & 0.98 & 9.5 & 10.0 & 11.3 & 0.1 & -2.3 \\
\hline \multirow[t]{2}{*}{$\varepsilon 3=5$} & 10.1 & 10.2 & 10.5 & 0.97 & 9.6 & 9.9 & 11.3 & 0.1 & -2.4 \\
\hline & $L_{n}$ & $L_{j}$ & $L_{x}$ & $u$ & $E A P G$ & $w_{n} / P$ & $w_{j} / P$ & $w_{s} / P$ & $\triangle T / G D P_{o}$ \\
\hline$\varepsilon 3=0.5$ & 5.2 & -0.7 & 0 & 5.8 & 10.3 & 5.2 & 10.0 & 10.1 & 0.47 \\
\hline$\varepsilon_{3}=5$ & 5.1 & -0.8 & 0.1 & 5.8 & 10.3 & 5.2 & 10.0 & 10.0 & 0.47 \\
\hline \multicolumn{10}{|c|}{ (c) Investment in basic education $\left(R_{b}=R_{z}=0.20\right)$} \\
\hline Calibration & GDP & $C / N N I$ & $k$ & $C I C$ & $q x$ & $q_{n}$ & $q_{j}$ & $P_{n}$ & $P_{j}$ \\
\hline$\varepsilon 3=0.5$ & 7.3 & 7.1 & 7.6 & 0.70 & 6.8 & 7.1 & 8.6 & 0.1 & -1.7 \\
\hline \multirow[t]{2}{*}{$\varepsilon_{3}=5$} & 7.3 & 7.0 & 7.5 & 0.70 & 6.8 & 7.0 & 8.5 & 0.1 & -1.7 \\
\hline & $L_{n}$ & $L_{j}$ & $L_{x}$ & $u$ & $E A P G$ & $w_{n} / P$ & $w_{j} / P$ & $w_{s} / P$ & $\Delta T / G D P_{o}$ \\
\hline$\varepsilon 3=0.5$ & 3.6 & -0.1 & -0.2 & 5.9 & 7.4 & 3.8 & 7.2 & 7.3 & 0.03 \\
\hline$\varepsilon 3=5$ & 3.5 & -0.2 & -0.1 & 5.9 & 7.4 & 3.8 & 7.2 & 7.3 & 0.03 \\
\hline
\end{tabular}


Table 4 (Cont.)

\begin{tabular}{|c|c|c|c|c|c|c|c|c|c|}
\hline \multicolumn{10}{|c|}{ (d) Investment in upper-level education } \\
\hline Calibration & $G D P$ & C/NNI & 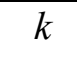 & $C I C$ & $q_{x}$ & $q_{n}$ & $q_{j}$ & $P_{n}$ & $P_{j}$ \\
\hline$\varepsilon 3=0.5$ & 6.2 & 6.5 & 2.7 & 0.25 & 3.0 & 10.1 & 6.6 & -13.6 & -6.2 \\
\hline \multirow[t]{2}{*}{$\varepsilon_{3}=5$} & 9.1 & 9.3 & 8.4 & 0.77 & 0.4 & 20.8 & 9.2 & -10.7 & -4.3 \\
\hline & $L_{n}$ & $L_{j}$ & $L_{x}$ & $u$ & $E A P G$ & $w_{n} / P$ & $w_{j} / P$ & $w_{\mathrm{s}} / P$ & $\triangle T / G D P_{o}$ \\
\hline$\varepsilon 3=0.5$ & -4.2 & -4.4 & -1.6 & 5.7 & 18.0 & 6.3 & 12.0 & -29.0 & -0.64 \\
\hline$\varepsilon 3=5$ & 6.9 & -0.3 & -4.2 & 5.3 & 18.1 & 6.5 & 10.7 & -24.1 & 0.02 \\
\hline \multicolumn{10}{|c|}{ (e) Investment in upper-level education $\left(R_{u}=R_{z}=0.20\right)$} \\
\hline Calibration & $G D P$ & $C / N N I$ & k & $C I C$ & $q x$ & $q_{n}$ & $q_{j}$ & $P_{n}$ & $P_{j}$ \\
\hline$\varepsilon 3=0.5$ & 4.7 & 4.6 & 2.1 & 0.19 & 2.2 & 7.4 & 5.4 & -10.4 & -4.6 \\
\hline \multirow[t]{2}{*}{$\varepsilon_{3}=5$} & 6.9 & 6.7 & 6.4 & 0.59 & 0.2 & 15.4 & 7.4 & -8.0 & -3.2 \\
\hline & $L_{n}$ & $L_{j}$ & $L_{x}$ & $u$ & $E A P G$ & $w_{n} / P$ & $w_{j} / P$ & $w_{s} / P$ & $\Delta T / G D P_{o}$ \\
\hline$\varepsilon 3=0.5$ & -3.2 & -2.9 & -1.3 & 5.8 & 14.0 & 4.7 & 8.9 & -22.6 & -0.74 \\
\hline$\varepsilon 3=5$ & 5.4 & 0.3 & -3.3 & 5.5 & 13.9 & 4.7 & 7.8 & -18.5 & -0.23 \\
\hline
\end{tabular}

${ }^{1}$ Solutions for all variables other than the crowding-in coefficient $(C I C)$, the unemployment rate, and the change in transfers are percentage deviations from the initial steady state. 
Table 5. The High Cost of Neglecting Maintenance. ${ }^{1}$

\begin{tabular}{|c|c|c|c|c|c|c|c|c|c|}
\hline \multicolumn{10}{|c|}{ (a) Gains from eating the free lunch ${ }^{2}$} \\
\hline Calibration & $G D P$ & $C / N N I$ & $k$ & $C I C$ & $q_{x}$ & $q_{n}$ & $q_{j}$ & $P_{n}$ & $P_{j}$ \\
\hline$\varepsilon_{3}=0.5$ & 3.3 & 3.2 & 2.8 & 0.69 & 3.2 & 3.6 & 3.0 & -1.5 & -0.1 \\
\hline \multirow[t]{2}{*}{$\varepsilon 3=5$} & 3.6 & 3.4 & 3.5 & 0.84 & 2.9 & 4.8 & 3.3 & -1.1 & 0.1 \\
\hline & $L_{n}$ & $L_{j}$ & $L_{x}$ & $\Delta u$ & $E A P G$ & $w_{n} / P$ & $w_{j} / P$ & $w_{s} / P$ & $\triangle T / G D P_{o}$ \\
\hline$\varepsilon 3=0.5$ & 0.7 & -0.2 & 0.1 & $\approx 0$ & 3.8 & 1.9 & 3.8 & 3.1 & $\approx 0$ \\
\hline$\varepsilon 3=5$ & 2.1 & 0.3 & -0.3 & $\approx 0$ & 3.7 & 1.9 & 3.6 & 3.9 & $\approx 0$ \\
\hline \multicolumn{10}{|c|}{ (b) Maintenance spending increases to its optimal level ${ }^{3}$} \\
\hline Calibration & $G D P$ & $C / N N I$ & $k$ & $C I C$ & $q_{x}$ & $q_{n}$ & $q_{j}$ & $P_{n}$ & $P_{j}$ \\
\hline$\varepsilon 3=0.5$ & 9.1 & 8.3 & 7.7 & 0.63 & 8.8 & 9.8 & 8.6 & -4.3 & -0.3 \\
\hline \multirow[t]{2}{*}{$\varepsilon_{3}=5$} & 10.0 & 9.1 & 9.6 & 0.78 & 7.9 & 13.3 & 9.4 & -3.1 & 0.3 \\
\hline & $L_{n}$ & $L_{j}$ & $L_{x}$ & $\Delta u^{3}$ & $E A P G$ & $w_{n} / P$ & $w_{j} / P$ & $w_{s} / P$ & $\Delta T / G D P_{o}$ \\
\hline$\varepsilon 3=0.5$ & 1.7 & -0.4 & 0.1 & -0.06 & 10.7 & 5.3 & 10.6 & 8.4 & -0.05 \\
\hline$\varepsilon 3=5$ & 5.6 & 1.0 & -0.8 & -0.19 & 10.3 & 5.2 & 10.0 & 10.8 & 0.18 \\
\hline
\end{tabular}

${ }^{1}$ Gains are calculated relative to an initial equilibrium where maintenance spending equals zero. The rate of unemployment at the initial equilibrium is $6.06 \%$ when $\varepsilon_{3}=.5$ and $6.19 \%$ when $\varepsilon_{3}=5$.

${ }^{2}$ The increase in maintenance spending equals $0.49 \%$ of GDP when maintenance is at its optimal level (i.e., the increase in maintenance spending is $49 \%$ as large as in Table 3 ).

${ }^{3}$ Maintenance increases from zero at the initial equilibrium to its optimal level. The direct net fiscal cost equals $1.154 \%$ of GDP when maintenance is at its optimal level. Adjusting for the larger endogenous increase in tax revenue, the net fiscal cost is $0.28 \%(0.38 \%)$ less than the fiscal cost of increasing new infrastructure investment by $1 \%$ of initial GDP when $\varepsilon_{3}=0.5\left(\varepsilon_{3}=5\right)$ in Table 3 . 
Table 6. Long-Run Effects of Big-Push Programs that Increase Public Investment. Increase of Four Percent of Initial GDP.

\begin{tabular}{|c|c|c|c|c|c|c|c|c|c|}
\hline \multicolumn{10}{|c|}{ (a) All investment goes to infrastructure } \\
\hline Calibration & $G D P$ & $C / N N I$ & $k$ & $C I C$ & $q x$ & $q_{n}$ & $q_{j}$ & $P_{n}$ & $P_{j}$ \\
\hline$\varepsilon_{3}=0.5$ & 16.2 & 12.5 & 13.2 & 0.44 & 15.9 & 16.4 & 16.2 & -7.3 & -0.6 \\
\hline \multirow[t]{2}{*}{$\varepsilon 3=5$} & 17.8 & 14.0 & 16.5 & 0.56 & 14.4 & 22.5 & 17.7 & -5.6 & 0.4 \\
\hline & $L_{n}$ & $L_{j}$ & $L_{x}$ & $u$ & $E A P G$ & $w_{n} / P$ & $w_{j} / P$ & $w_{s} / P$ & $\triangle T / G D P_{o}$ \\
\hline$\varepsilon 3=0.5$ & 1.6 & -0.3 & 0.1 & 5.9 & 19.5 & 9.4 & 19.5 & 14.6 & -1.7 \\
\hline$\varepsilon 3=5$ & 8.0 & 1.9 & -1.4 & 5.7 & 19.0 & 9.4 & 18.6 & 18.8 & -1.3 \\
\hline \multicolumn{10}{|c|}{ (b) All investment goes to basic education } \\
\hline Calibration & $G D P$ & $C / N N I$ & $k$ & $C I C$ & $q_{x}$ & $q_{n}$ & $q_{j}$ & $P_{n}$ & $P_{j}$ \\
\hline$\varepsilon 3=0.5$ & 37.5 & 37.5 & 39.2 & 0.9 & 35.0 & 36.8 & 42.5 & 0.4 & -7.5 \\
\hline \multirow[t]{2}{*}{$\varepsilon_{3}=5$} & 37.4 & 37.4 & 38.9 & 0.9 & 35.1 & 36.3 & 42.4 & 0.3 & -7.6 \\
\hline & $L_{n}$ & $L_{j}$ & $L_{x}$ & $u$ & $E A P G$ & $w_{n} / P$ & $w_{j} / P$ & $w_{s} / P$ & $\triangle T / G D P_{o}$ \\
\hline$\varepsilon 3=0.5$ & 17.8 & -2.3 & 0 & 5.4 & 38.0 & 18.3 & 36.8 & 37.3 & 1.5 \\
\hline$\varepsilon 3=5$ & 17.3 & -2.4 & 0.1 & 5.4 & 38.0 & 18.3 & 36.9 & 37.0 & 1.4 \\
\hline \multicolumn{10}{|c|}{$\begin{array}{l}\text { (c) Investment in basic and upper-level education } \\
\text { Increases of } 2.67 \% \text { and } 1.33 \% \text { of initial GDP, respectively }\end{array}$} \\
\hline Calibration & $G D P$ & $C / N N I$ & $k$ & $C I C$ & $q_{x}$ & $q_{n}$ & $q_{j}$ & $P_{n}$ & $P_{j}$ \\
\hline$\varepsilon 3=0.5$ & 35.5 & 36.4 & 31.0 & 0.72 & 28.8 & 41.4 & 39.2 & -16.6 & -12.8 \\
\hline \multirow[t]{2}{*}{$\varepsilon 3=5$} & 40.2 & 40.8 & 39.8 & 0.92 & 25.0 & 58.0 & 43.3 & -13.1 & -10.6 \\
\hline & $L_{n}$ & $L_{j}$ & $L_{x}$ & $u$ & $E A P G$ & $w_{n} / P$ & $w_{j} / P$ & $w_{s} / P$ & $\triangle T / G D P_{o}$ \\
\hline$\varepsilon 3=0.5$ & 6.5 & -7.6 & -2.0 & 5.2 & 54.5 & 22.0 & 44.7 & -18.6 & 0.3 \\
\hline$\varepsilon 3=5$ & 21.3 & -2.9 & -5.2 & 4.7 & 55.1 & 22.5 & 42.7 & -11.6 & 1.3 \\
\hline
\end{tabular}


Table 6 (Cont.)

\begin{tabular}{|c|c|c|c|c|c|c|c|c|c|}
\hline \multicolumn{10}{|c|}{$\begin{array}{c}\text { (d) Investment in infrastructure, basic education, and upper-level education } \\
\text { Increases of } 1 \%, 2 \% \text {, and } 1 \% \text { of initial GDP, respectively }\end{array}$} \\
\hline Calibration & $G D P$ & $C / N N I$ & $k$ & $C I C$ & $q_{x}$ & $q_{n}$ & $q_{j}$ & $P_{n}$ & $\bar{P}$ \\
\hline$\varepsilon_{3}=.5$ & 33.0 & 33.2 & 28.7 & 0.72 & 27.7 & 38.1 & 35.5 & -15.3 & -10.4 \\
\hline \multirow[t]{2}{*}{$\varepsilon 3=5$} & 37.2 & 37.1 & 36.6 & 0.92 & 24.2 & 53.1 & 39.1 & -12.1 & -8.4 \\
\hline & $L_{n}$ & $L_{j}$ & $L_{x}$ & $u$ & $E A P G$ & $w_{n} / P$ & $w_{j} / P$ & $w_{s} / P$ & $\Delta T / G D P_{o}$ \\
\hline$\varepsilon 3=.5$ & 6.0 & -6.2 & -1.3 & 5.4 & 49.7 & 20.1 & 40.9 & -11.5 & 0.1 \\
\hline$\varepsilon 3=5$ & 19.8 & -1.8 & -4.3 & 4.9 & 50.0 & 20.4 & 39.1 & -4.6 & 1.1 \\
\hline \multicolumn{10}{|c|}{$\begin{array}{l}\text { (e) Investment in infrastructure, basic education, and upper-level education } \\
\text { Increases } 1.6 \%, 1.6 \% \text {, and } 0.8 \% \text { of initial GDP, respectively }\end{array}$} \\
\hline Calibration & $G D P$ & $C / N N I$ & $k$ & $C I C$ & $q_{x}$ & $q_{n}$ & $q_{j}$ & $P_{n}$ & $P_{j}$ \\
\hline$\varepsilon 3=.5$ & 30.7 & 30.3 & 26.5 & 0.70 & 26.3 & 35.0 & 32.6 & -14.3 & -8.8 \\
\hline \multirow[t]{2}{*}{$\varepsilon_{3}=5$} & 34.5 & 33.9 & 33.8 & 0.89 & 23.1 & 48.7 & 35.9 & -11.2 & -6.9 \\
\hline & $L_{n}$ & $\bar{L} L_{j}$ & $L_{x}$ & $u$ & $E A P G$ & $w_{n} / P$ & $w_{j} / P$ & $w_{s} / P$ & $\Delta T / G D P_{o}$ \\
\hline$\varepsilon_{3}=.5$ & 5.5 & -5.3 & -1.0 & 5.5 & 45.5 & 18.5 & 37.8 & -7.0 & -0.1 \\
\hline$\varepsilon 3=5$ & 18.3 & -1.1 & -3.8 & 5.0 & 45.5 & 18.8 & 36.1 & -0.2 & 0.8 \\
\hline
\end{tabular}


Table 7. Comparison of Welfare Gains in the Base Case $\boldsymbol{R}_{u}=\boldsymbol{R}_{b}=\mathbf{0 . 3 0}\left(\varepsilon_{3}=5\right)$. Welfare Metric Allows for Diminishing Marginal Utility of Consumption. ${ }^{1}$

\begin{tabular}{|c|c|c|c|c|c|c|}
\hline \multicolumn{7}{|c|}{$\zeta=\mathbf{0}$} \\
\hline $\begin{array}{c}i_{z} \text { share } \\
(\%)\end{array}$ & $\beta_{S}=0.93$ & $\beta_{S}=0.94$ & $\beta_{s}=0.95$ & $\beta_{s}=0.96$ & $\beta_{s}=0.97$ & $\beta_{S}=0.98$ \\
\hline 0 & 3.8 & 5.1 & 6.7 & 9.0 & 12.3 & 17.3 \\
\hline 25 & 4.3 & 5.4 & 7.0 & 9.1 & 12.1 & 16.6 \\
\hline 37.5 & 4.3 & 5.4 & 6.9 & 8.9 & 11.7 & 15.9 \\
\hline 50 & 4.3 & 5.3 & 6.7 & 8.5 & 11.1 & 14.9 \\
\hline 62.5 & 4.2 & 5.1 & 6.4 & 8.0 & 10.3 & 13.6 \\
\hline 75 & 4.0 & 4.8 & 5.9 & 7.3 & 9.3 & 12.1 \\
\hline 100 & 3.4 & 3.9 & 4.6 & 5.5 & 6.7 & 8.3 \\
\hline \multicolumn{7}{|c|}{$\zeta=1$} \\
\hline $\begin{array}{c}i_{z} \text { share } \\
(\%)\end{array}$ & $\beta_{s}=0.93$ & $\beta_{S}=0.94$ & $\beta_{s}=0.95$ & $\beta_{s}=0.96$ & $\beta_{s}=0.97$ & $\beta_{s}=0.98$ \\
\hline 0 & 5.6 & 7.0 & 9.0 & 11.6 & 15.3 & 20.8 \\
\hline 25 & 6.0 & 7.4 & 9.2 & 11.6 & 14.9 & 19.9 \\
\hline 37.5 & 6.1 & 7.4 & 9.0 & 11.3 & 14.4 & 19.0 \\
\hline 50 & 6.1 & 7.3 & 8.8 & 10.9 & 13.7 & 17.9 \\
\hline 62.5 & 6.0 & 7.0 & 8.4 & 10.3 & 12.8 & 16.4 \\
\hline 75 & 5.8 & 6.7 & 7.9 & 9.5 & 11.6 & 14.7 \\
\hline 100 & 5.1 & 5.7 & 6.4 & 7.4 & 8.6 & 10.3 \\
\hline \multicolumn{7}{|c|}{$\zeta=2$} \\
\hline $\begin{array}{c}i_{z} \text { share } \\
(\%)\end{array}$ & $\beta_{S}=0.93$ & $\beta_{s}=0.94$ & $\beta_{S}=0.95$ & $\beta_{S}=0.96$ & $\beta_{s}=0.97$ & $\beta_{s}=0.98$ \\
\hline 0 & 6.4 & 7.9 & 9.9 & 12.7 & 16.6 & 22.3 \\
\hline 25 & 6.8 & 8.2 & 10.1 & 12.6 & 16.1 & 21.3 \\
\hline 37.5 & 6.8 & 8.2 & 10.0 & 12.3 & 15.6 & 20.4 \\
\hline 50 & 6.8 & 8.1 & 9.7 & 11.9 & 14.9 & 19.2 \\
\hline 62.5 & 6.7 & 7.9 & 9.3 & 11.3 & 13.9 & 17.6 \\
\hline 75 & 6.5 & 7.5 & 8.8 & 10.4 & 12.7 & 15.8 \\
\hline 100 & 5.8 & 6.4 & 7.2 & 8.2 & 9.5 & 11.1 \\
\hline
\end{tabular}

${ }^{1}$ All runs set the ceiling on the VAT at 0.22 and allow transfers to decrease by $1 \%$ of initial GDP. 
Table 8. Comparison of Welfare Gains When $\boldsymbol{R}_{u}=\boldsymbol{R}_{b}=0.20\left(\varepsilon_{3}=5\right)$.

Welfare Metric Allows for Diminishing Marginal Utility of Consumption. ${ }^{1}$

\begin{tabular}{|c|c|c|c|c|c|c|}
\hline \multicolumn{7}{|c|}{$\zeta=\mathbf{0}$} \\
\hline $\begin{array}{c}i_{z} \text { share } \\
(\%)\end{array}$ & $\beta_{s}=0.93$ & $\beta_{s}=0.94$ & $\beta_{s}=0.95$ & $\beta_{s}=0.96$ & $\beta_{s}=0.97$ & $\beta_{s}=0.98$ \\
\hline 0 & 1.8 & 2.7 & 3.9 & 5.6 & 8.0 & 11.7 \\
\hline 25 & 2.7 & 3.5 & 4.7 & 6.3 & 8.5 & 11.9 \\
\hline 37.5 & 3.0 & 3.8 & 4.9 & 6.4 & 8.6 & 11.8 \\
\hline 50 & 3.2 & 4.0 & 5.0 & 6.5 & 8.5 & 11.5 \\
\hline 62.5 & 3.3 & 4.1 & 5.1 & 6.4 & 8.3 & 11.0 \\
\hline 75 & 3.4 & 4.1 & 5.0 & 6.2 & 7.9 & 10.3 \\
\hline 100 & 3.4 & 3.9 & 4.6 & 5.5 & 6.7 & 8.3 \\
\hline \multicolumn{7}{|c|}{$\zeta=1$} \\
\hline $\begin{array}{c}i_{z} \text { share } \\
(\%)\end{array}$ & $\beta_{s}=0.93$ & $\beta_{S}=0.94$ & $\beta_{s}=0.95$ & $\beta_{S}=0.96$ & $\beta_{s}=0.97$ & $\beta_{s}=0.98$ \\
\hline 0 & 3.7 & 4.7 & 6.1 & 8.1 & 10.8 & 14.9 \\
\hline 25 & 4.4 & 5.4 & 6.8 & 8.6 & 11.2 & 14.9 \\
\hline 37.5 & 4.7 & 5.7 & 7.0 & 8.7 & 11.2 & 14.7 \\
\hline 50 & 4.9 & 5.9 & 7.1 & 8.7 & 11.0 & 14.2 \\
\hline 62.5 & 5.1 & 5.9 & 7.1 & 8.6 & 10.6 & 13.6 \\
\hline 75 & 5.1 & 5.9 & 7.0 & 8.3 & 10.1 & 12.7 \\
\hline 100 & 5.0 & 5.7 & 6.4 & 7.4 & 8.6 & 10.3 \\
\hline \multicolumn{7}{|c|}{$\zeta=2$} \\
\hline $\begin{array}{c}i_{z} \text { share } \\
(\%)\end{array}$ & $\beta_{S}=0.93$ & $\beta_{S}=0.94$ & $\beta_{S}=0.95$ & $\beta_{s}=0.96$ & $\beta_{s}=0.97$ & $\beta_{S}=0.98$ \\
\hline 0 & 4.4 & 5.6 & 7.1 & 9.2 & 12.1 & 16.3 \\
\hline 25 & 5.2 & 6.3 & 7.7 & 9.7 & 12.3 & 16.3 \\
\hline 37.5 & 5.5 & 6.5 & 7.9 & 9.7 & 12.3 & 16.0 \\
\hline 50 & 5.7 & 6.7 & 8.0 & 9.7 & 12.1 & 15.4 \\
\hline 62.5 & 5.8 & 6.8 & 8.0 & 9.5 & 11.7 & 14.7 \\
\hline 75 & 5.9 & 6.7 & 7.8 & 9.2 & 11.1 & 13.7 \\
\hline 100 & 5.8 & 6.4 & 7.2 & 8.2 & 9.5 & 11.1 \\
\hline
\end{tabular}

${ }^{1}$ To ensure debt sustainability, the runs when the $i_{z}$ share equals zero set the ceiling on the VAT at 0.22 and allow transfers to decrease by $1.5 \%$ of initial GDP. In all other runs, the ceiling on the VAT equals 0.22 and transfers cannot decrease more than $1 \%$ of initial GDP. 
Table 9. Comparison of Welfare Gains When $R_{u}=R_{b}=0.15\left(\varepsilon_{3}=5\right)$.

Welfare Metric Allows for Diminishing Marginal Utility of Consumption. ${ }^{1}$

\begin{tabular}{|c|c|c|c|c|c|c|}
\hline \multicolumn{7}{|c|}{$\zeta=\mathbf{0}$} \\
\hline $\begin{array}{c}i_{z} \text { share } \\
(\%)\end{array}$ & $\beta_{s}=0.93$ & $\beta_{S}=0.94$ & $\beta_{S}=0.95$ & $\beta_{s}=0.96$ & $\beta_{s}=0.97$ & $\beta_{S}=0.98$ \\
\hline 0 & .8 & 1.4 & 2.4 & 3.7 & 5.6 & 8.5 \\
\hline 25 & 1.8 & 2.5 & 3.4 & 4.7 & 6.6 & 9.4 \\
\hline 37.5 & 2.2 & 2.9 & 3.9 & 5.1 & 7.0 & 9.7 \\
\hline 50 & 2.6 & 3.3 & 4.2 & 5.4 & 7.1 & 9.7 \\
\hline 62.5 & 2.9 & 3.5 & 4.4 & 5.6 & 7.2 & 9.6 \\
\hline 75 & 3.1 & 3.7 & 4.5 & 5.6 & 7.1 & 9.3 \\
\hline 100 & 3.4 & 3.9 & 4.6 & 5.5 & 6.7 & 8.3 \\
\hline \multicolumn{7}{|c|}{$\zeta=1$} \\
\hline $\begin{array}{c}i_{z} \text { share } \\
(\%)\end{array}$ & $\beta_{S}=0.93$ & $\beta_{S}=0.94$ & $\beta_{s}=0.95$ & $\beta_{S}=0.96$ & $\beta_{s}=0.97$ & $\beta_{S}=0.98$ \\
\hline 0 & 2.6 & 3.4 & 4.6 & 6.1 & 8.3 & 11.6 \\
\hline 25 & 3.6 & 4.4 & 5.5 & 7.0 & 9.1 & 12.2 \\
\hline 37.5 & 4.0 & 4.8 & 5.9 & 7.4 & 9.4 & 12.4 \\
\hline 50 & 4.3 & 5.1 & 6.2 & 7.6 & 9.5 & 12.3 \\
\hline 62.5 & 4.6 & 5.4 & 6.4 & 7.7 & 9.5 & 12.1 \\
\hline 75 & 4.8 & 5.5 & 6.5 & 7.7 & 9.3 & 11.6 \\
\hline 100 & 5.0 & 5.7 & 6.4 & 7.4 & 8.6 & 10.3 \\
\hline \multicolumn{7}{|c|}{$\zeta=2$} \\
\hline $\begin{array}{c}i_{z} \text { share } \\
(\%)\end{array}$ & $\beta_{s}=0.93$ & $\beta_{S}=0.94$ & $\beta_{S}=0.95$ & $\beta_{s}=0.96$ & $\beta_{S}=0.97$ & $\beta_{s}=0.98$ \\
\hline 0 & 3.4 & 4.3 & 5.5 & 7.2 & 9.5 & 13.0 \\
\hline 25 & 4.3 & 5.2 & 6.4 & 8.0 & 10.2 & 13.5 \\
\hline 37.5 & 4.7 & 5.6 & 6.8 & 8.4 & 10.5 & 13.6 \\
\hline 50 & 5.1 & 5.9 & 7.1 & 8.6 & 10.6 & 13.5 \\
\hline 62.5 & 5.3 & 6.2 & 7.2 & 8.6 & 10.5 & 13.2 \\
\hline 75 & 5.5 & 6.3 & 7.3 & 8.6 & 10.3 & 12.7 \\
\hline 100 & 5.8 & 6.4 & 7.2 & 8.2 & 9.5 & 11.1 \\
\hline
\end{tabular}

${ }^{1}$ To ensure debt sustainability, the runs when the $i_{z}$ share equals zero set the ceiling on the VAT at 0.22 and allow transfers to decrease by $1.5 \%$ of initial GDP. In all other runs, the ceiling on the VAT equals 0.22 and transfers cannot decrease more than $1 \%$ of initial GDP. 


\section{FIGURES}

Figure 1. Correcting Sub-Optimal Maintenance Is a Free Lunch.

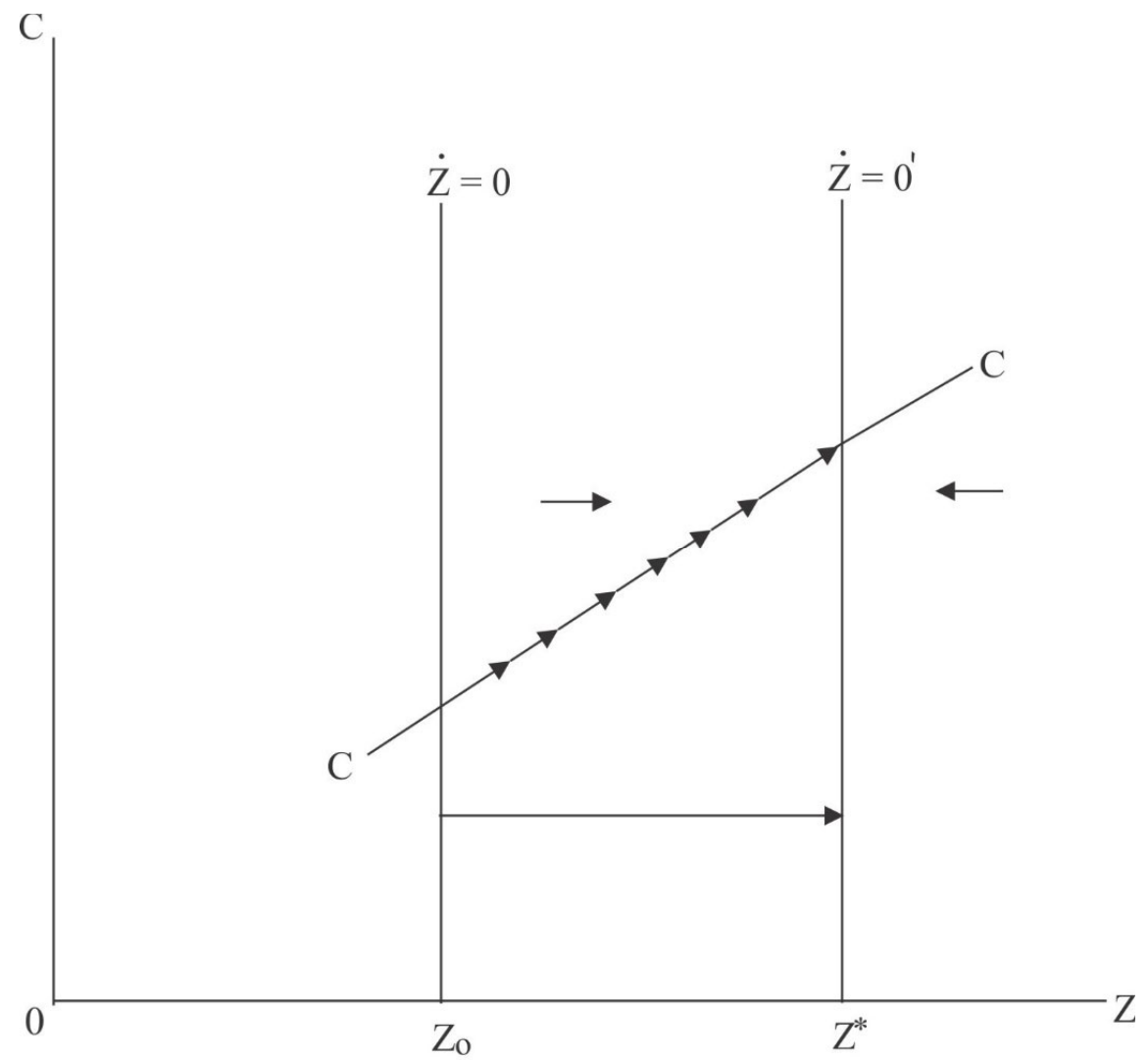


Figure 2. Relationship Between Marginal General Equilibrium Returns and the Impact of the Investment Mix on Long-Run Output.

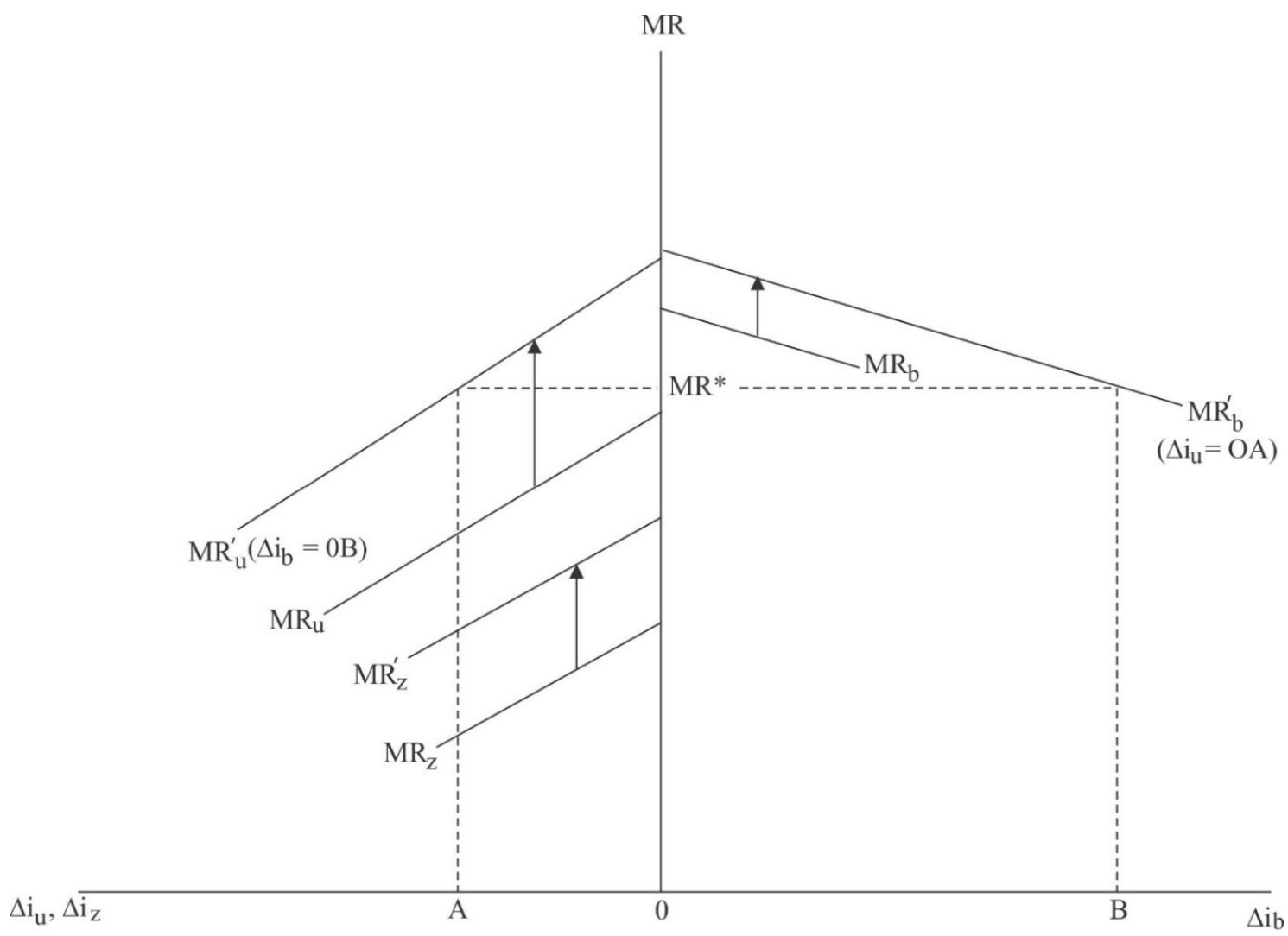


Figure 3. Transition Paths for All-Infrastructure and All-Human Capital (Education) Investment Programs.
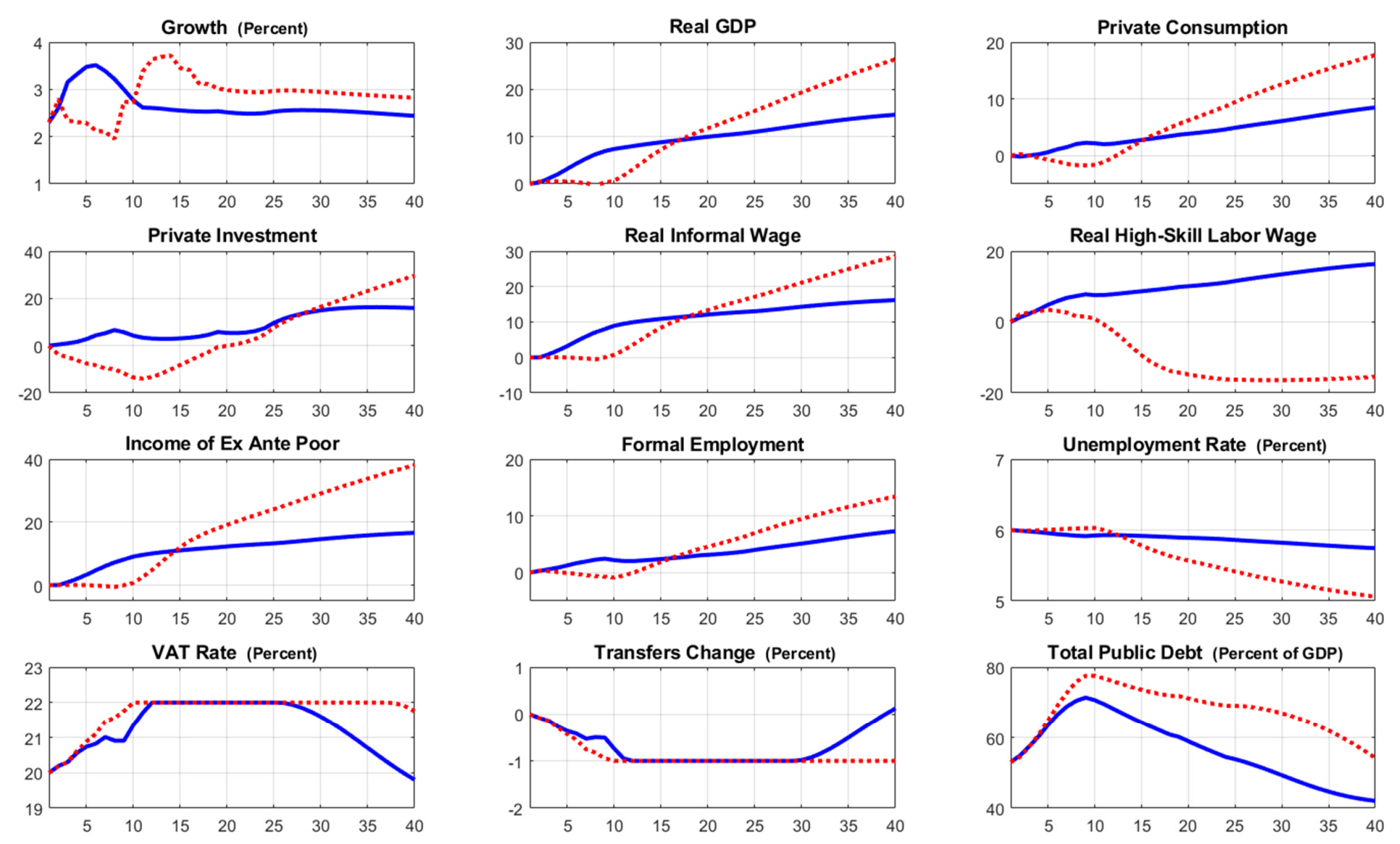

— All-Infrastructure Investment Program …... All-Human Capital Investment Program

Note: Variables are expressed as percentage deviations from the initial steady state, unless otherwise noted. 


\section{Figure 4. Transition Paths for All-Infrastructure and Mixed Investment Programs.}
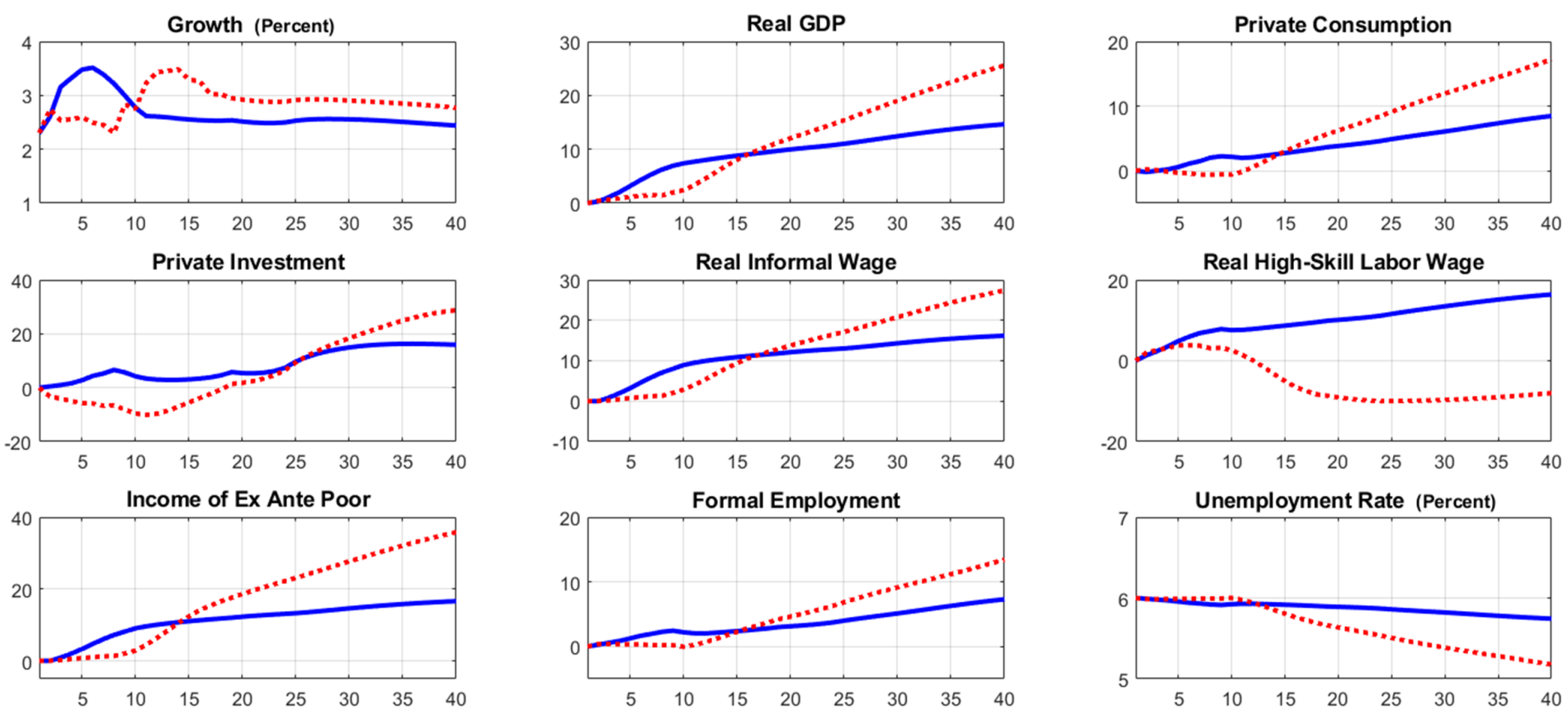

Unemployment Rate (Percent)
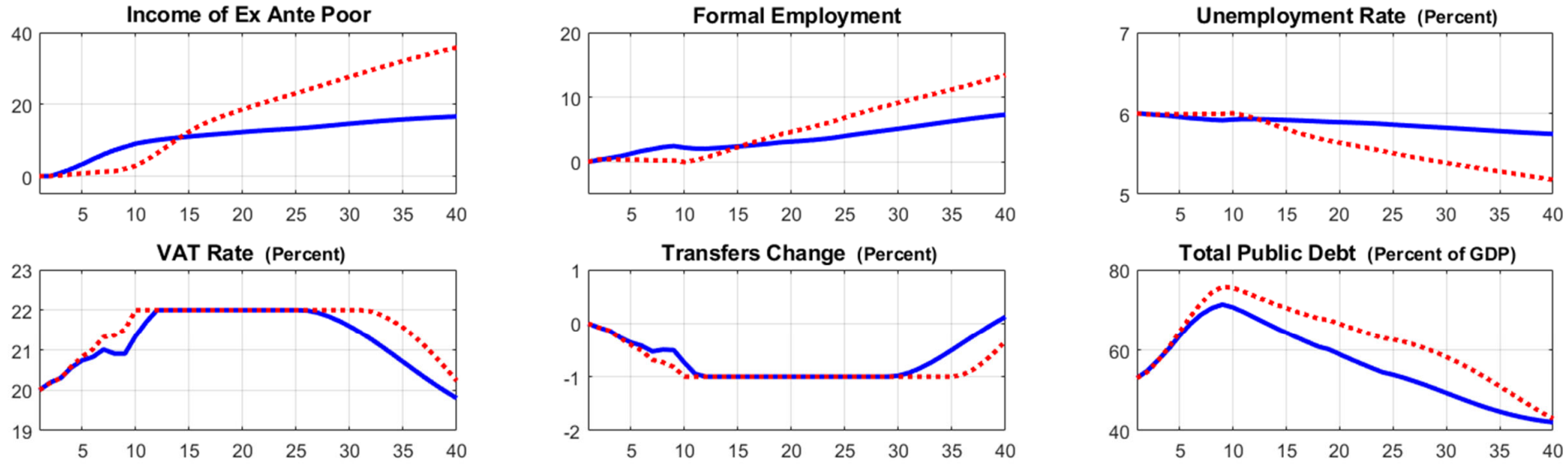

All-Infrastructure Investment Program ...... Mixed Investment Program

Note: Variables are expressed as percentage deviations from the initial steady state, unless otherwise noted. 
Appendix A. Formal Sector Wage Premium and the Earnings Gap Between the Informal Sector and Agriculture.

\begin{tabular}{|c|c|c|}
\hline Study, Country & Data, Estimation Technique & Wage Premia \\
\hline $\begin{array}{l}\text { Badaoui et al. (2010) } \\
\text { Ecuador, } 1994\end{array}$ & $\begin{array}{l}\text { Excludes farmers and self- } \\
\text { employed individuals. } \\
\text { Propensity Score Matching }\end{array}$ & $\begin{array}{l}\text { Formal sector, net wage: } 0 \text { controlling for firm size; } 35.1 \% \text { with firm size } \\
\text { effect. } \\
\text { Formal sector, gross wage: } 26.9 \% \text { controlling for firm size; } 47 \% \text { with firm } \\
\text { size effect. }\end{array}$ \\
\hline $\begin{array}{l}\text { Heintz and Slonimczyk (2007) } \\
\text { Ghana, 1998-1999 }\end{array}$ & $\begin{array}{l}\text { Mincer earnings functions; no } \\
\text { controls for selection bias. }\end{array}$ & $\begin{array}{l}\text { Formal sector vs. informal wage: } 73.7-111 \% . \\
\text { Formal sector vs. agriculture. self-employment: } 91.4-129 \% \text {. } \\
\text { Formal sector vs. agriculture. wage employment: } 148-335 \% \text {. } \\
\text { Informal sector vs. agriculture. (all workers): } 31 \% .\end{array}$ \\
\hline $\begin{array}{l}\text { Schaffner (1998) } \\
\text { Peru, 1985-1986 }\end{array}$ & $\begin{array}{l}\text { Urban males. Earnings functions; } \\
\text { no controls for selection bias. }\end{array}$ & \begin{tabular}{lclr} 
Firm size effect (\%) vis-à-vis microenterprise: \\
& & & \\
& Blue Collar & White Collar & All \\
Small & $15.0-19.8$ & $39.2-53.3$ & 28.3 \\
Medium & 23.9 & $70.1-92.5$ & 51.0 \\
Large & $41.3-52.2$ & $71.4-117.0$ & 73.3 \\
\multicolumn{4}{l}{} \\
Controls for minimum wage law and unionization.
\end{tabular} \\
\hline $\begin{array}{c}\text { Funkhouser (1997b) } \\
\text { El Salvador, 1991-1992 }\end{array}$ & $\begin{array}{l}\text { Urban workers. Panel data with } \\
\text { premium computed for job } \\
\text { changers vs. job stayers. }\end{array}$ & $\begin{array}{l}\text { Formal sector, unskilled labor: } \\
\qquad \begin{array}{l}107 \% \text { for males } \\
61.4 \% \text { for females. }\end{array}\end{array}$ \\
\hline
\end{tabular}




\begin{tabular}{|c|c|c|}
\hline Study, Country & Data, Estimation Technique & Wage Premia \\
\hline $\begin{array}{c}\text { Jaffry et al. (2006) } \\
\text { Pakistan, 1990/91-2003/04 }\end{array}$ & $\begin{array}{l}\text { Earnings functions; no control for } \\
\text { self-selection. }\end{array}$ & $\begin{array}{l}\text { Industry vs. agriculture.: } 35-49 \% \text {. } \\
\text { Industry vs. services and food + textiles: } 24-27 \% \text {. } \\
\text { Estimates control for firm size. }\end{array}$ \\
\hline $\begin{array}{l}\text { Mizala and Romaguera (1998) } \\
\text { Chile, 1985-1991 }\end{array}$ & $\begin{array}{l}\text { Earnings functions with firm size } \\
\text { dummy variables. }\end{array}$ & $\begin{array}{l}\text { Firm size premium: } \\
\qquad \begin{array}{l}\text { Medium vs. small }=35 \% \\
\text { Large vs. small }=66.4 \% .\end{array}\end{array}$ \\
\hline $\begin{array}{c}\text { Funkhouser (1998) } \\
\text { Guatemala, 1989-1990 }\end{array}$ & $\begin{array}{l}\text { Private firms with } 10+\text { workers in } \\
\text { the capital city. Earnings functions. }\end{array}$ & $\begin{array}{l}\text { Firm size premium: } \\
\qquad \begin{aligned} 26-50 \text { employees }=4.8 \% \\
51-100 \text { employees }=36.9 \% \\
101-500 \text { employees }=10.4 \% \\
500+\text { employees }=21.0 \%\end{aligned} \\
\text { Union wage premium }=43.5-57.3 \% .\end{array}$ \\
\hline $\begin{array}{l}\text { Funkhouser (1997a) } \\
\text { Guatemala, } 1989\end{array}$ & $\begin{array}{l}\text { Earnings functions with and } \\
\text { without Heckman 2-stage } \\
\text { correction for selection bias. }\end{array}$ & $\begin{array}{l}\text { Formal sector premium: } \\
\qquad \begin{array}{l}\text { No correction for selection: } 69.6 \% \text {. } \\
\text { Heckman 2-stage correction: } 77.9 \% \text {. }\end{array}\end{array}$ \\
\hline
\end{tabular}




\begin{tabular}{|c|c|c|}
\hline Study, Country & Data, Estimation Technique & Wage Premia \\
\hline $\begin{array}{l}\text { Gong and van Soest (2002) } \\
\text { Mexico, 1992-1993 }\end{array}$ & $\begin{array}{l}\text { Employment surveys covering } 60 \% \\
\text { of urban population. Dynamic } \\
\text { random effects estimator controls } \\
\text { for time-invariant heterogeneity } \\
\text { that affects sector choice and } \\
\text { earnings. }\end{array}$ & $\begin{array}{l}\text { Formal sector wage premium for educated workers: } \\
\qquad \text { High: male }=89 \% \text {, female }=96 \% \\
\text { Mid-level: male }=21 \% \text {, female }=49.5 \% \\
\text { No wage premium for low-education workers in the formal sector. But } \\
\text { earnings in the informal sector mix earnings of the self-employed and wage } \\
\text { employees. }\end{array}$ \\
\hline $\begin{array}{l}\text { Kingdon et al. (2005) } \\
\text { Tanzania, South Africa, Ghana, } \\
\text { Nigeria, and Kenya, 1992-2001 }\end{array}$ & $\begin{array}{l}\text { Labor force and household surveys. } \\
\text { Earning function with controls for } \\
\text { human capital characteristics. }\end{array}$ & $\begin{array}{l}\text { Union wage premium: } 3 \% \text { in Kenya, } 14 \% \text { in Nigeria, } 21 \% \text { in Tanzania, } 23 \% \\
\text { in South Africa, and } 28 \% \text { in Ghana. Firm-size premium adds } 37 \% \text { in Ghana, } \\
17 \% \text { in Kenya, } 30 \% \text { in Nigeria, and } 15 \% \text { in Tanzania. }\end{array}$ \\
\hline $\begin{array}{l}\text { Heintz and Posel (2008) } \\
\text { South Africa, } 2004\end{array}$ & $\begin{array}{l}\text { Earnings functions; no control for } \\
\text { selection bias. }\end{array}$ & $\begin{array}{l}\text { Formal vs. informal sector: } 83.8-131.2 \% \\
\text { Formal vs. agriculture: } 143.8-172.6 \% \\
\text { Informal vs. agriculture: } 38.7-46.1 \%\end{array}$ \\
\hline $\begin{array}{l}\text { Alcaraz et al. (2011) } \\
\text { Mexico, 2001-2004 }\end{array}$ & $\begin{array}{l}\text { Panel data restricted to urban } \\
\text { workers in services and industry. } \\
\text { Wage premium computed from job } \\
\text { changers vs. stayers. }\end{array}$ & Formal sector premium $=13.4 \%$. \\
\hline
\end{tabular}




\begin{tabular}{|c|c|c|}
\hline Study, Country & Data, Estimation Technique & Wage Premia \\
\hline $\begin{array}{l}\text { Baskaya and Hulagu (2011) } \\
\text { Turkey, 2005-2009 }\end{array}$ & Propensity Score Matching & $\begin{array}{l}\text { Firm size premium: } \\
\qquad \begin{array}{l}10-24 \text { employees }=17.8 \% \\
25-49 \text { employees }=19.7 \% \\
50-249 \text { employees }=28.3 \% \\
250-499 \text { employees }=36.8 \% \\
500+\text { employees }=47.7 \% \\
\text { Average }=30.1 \%\end{array} \\
\text { Formal sector premium controlling for firm size }=21.5 \% \text { (2009). Premium } \\
\text { with average firm size effect }=51.6 \% .\end{array}$ \\
\hline $\begin{array}{l}\text { Harati (2013) } \\
\text { Egypt, } 2006\end{array}$ & $\begin{array}{l}\text { Sample restricted to wage earners. } \\
\text { Earnings functions; no correction } \\
\text { for selection bias. }\end{array}$ & Formal sector premium $=38.8 \%$ \\
\hline $\begin{array}{c}\text { Gunther and Launov (2012) } \\
\text { Côte d'Ivoire, } 1998\end{array}$ & $\begin{array}{l}\text { Urban population. Estimates } \\
\text { distinct earnings functions for } \\
\text { different segments of the labor } \\
\text { market. Finite mixed regressions } \\
\text { with controls for selection bias. }\end{array}$ & $\begin{array}{l}\text { Two-tiered informal labor market: voluntary employment in upper tier, } \\
\text { involuntary employment in lower tier. Fraction of workers who would be } \\
\text { better off in formal sector twice the sector's employment share. }\end{array}$ \\
\hline $\begin{array}{l}\text { Carneiro and Henley (2001) } \\
\text { Brazil, } 1997\end{array}$ & $\begin{array}{l}\text { Nationally representative } \\
\text { household survey. Earnings } \\
\text { functions with Heckman 2-stage } \\
\text { correction for selection bias. }\end{array}$ & $\begin{array}{l}\text { Union wage premium }=16 \% \text { in the formal sector and } 17.6 \% \text { in the informal } \\
\text { sector. }\end{array}$ \\
\hline
\end{tabular}




\begin{tabular}{|c|c|c|}
\hline Study, Country & Data, Estimation Technique & Wage Premia \\
\hline $\begin{array}{l}\text { Fafchamps and Soderbom (2006) } \\
9 \text { countries in SSA + Morocco, } \\
1996-1998\end{array}$ & $\begin{array}{l}\text { Matched employer-employee data. } \\
\text { Sample restricted to firms with } 6+ \\
\text { employees and mainly covers the } \\
\text { formal sector. Controls for human } \\
\text { capital characteristics and firm-year } \\
\text { fixed effects. }\end{array}$ & Robust firm-size effect. Doubling of employment increases wages $8-9 \%$. \\
\hline $\begin{array}{c}\text { Lachaud (1995) } \\
\text { Burkina Faso, Cameroon, } \\
\text { Mali, Côte d'Ivoire, 1986-1992 }\end{array}$ & $\begin{array}{l}\text { Household survey for large urban } \\
\text { areas. Earnings functions with con- } \\
\text { trols for human capital characteristics } \\
\text { and selection bias. }\end{array}$ & $\begin{array}{l}\text { Formal sector premium: Burkina Faso }=57.1 \% \text {; Côte d'Ivoire }=40.9 \% \text {; Cameroon } \\
=60.3 \% \text {; Mali }=9.6 \% .\end{array}$ \\
\hline $\begin{array}{l}\text { Kingdon et al. (2005) } \\
\text { South Africa, 1993-2002 }\end{array}$ & $\begin{array}{l}\text { Nationally representative household } \\
\text { surveys. Earnings functions with } \\
\text { correction for selection bias. }\end{array}$ & Formal sector premium $=64 \%$. \\
\hline $\begin{array}{l}\text { Soderbom et al. (2005) } \\
\text { Kenya and Ghana, 1995-2000 }\end{array}$ & $\begin{array}{l}\text { Panel data for manufacturing. Fixed } \\
\text { effects estimator controls for } \\
\text { unobserved worker heterogeneity. } \\
\text { One-step GMM estimator for Ghana } \\
\text { corrects for measurement error. }\end{array}$ & $\begin{array}{l}\text { Firm size premium for } 50 \text { vs. } 10 \text { employees: } \\
\qquad \begin{array}{l}\text { Kenya }=13 \% \\
\text { Ghana }=27.1 \%\end{array}\end{array}$ \\
\hline $\begin{array}{l}\text { Pratap and Quintin (2006) } \\
\text { Argentina, 1993-1995, urban } \\
\text { households in Greater Buenos Aires } \\
\text { area. }\end{array}$ & Propensity Score Matching & $\begin{array}{l}\text { Firm size premium }=19.4-30.8 \% \\
\text { Size premium }+ \text { payroll taxes paid by formal firms }=37-48.3 \% \text {. }\end{array}$ \\
\hline $\begin{array}{l}\text { Thomas and Vallee (1996) } \\
\text { Cameroon }\end{array}$ & $\begin{array}{l}\text { Controls for self-selection through } \\
\text { estimation of a multinomial logit } \\
\text { model in the first stage. }\end{array}$ & Minimum wage laws generate wage gap in formal vs. informal sector of $38-65 \%$. \\
\hline
\end{tabular}




\begin{tabular}{|c|c|c|}
\hline Study, Country & Data, Estimation Technique & Wage Premia \\
\hline $\begin{array}{l}\text { Soderbom and Teal (2004) } \\
\text { Ghana, 1991-97. 7-year } \\
\text { panel of plant-level data }\end{array}$ & $\begin{array}{l}\text { Controls for human capital } \\
\text { and firm characteristics }\end{array}$ & $\begin{array}{l}\text { Wage premium for average firm size vs. micro firms ( } 5 \text { for fewer employees) } \\
=47.6-59.3 \% \text {. }\end{array}$ \\
\hline $\begin{array}{l}\text { Aigbokhan (2011) } \\
\text { Nigeria, 1998-2000 }\end{array}$ & $\begin{array}{l}\text { Mincer earnings functions; no } \\
\text { controls for selection bias. }\end{array}$ & $\begin{array}{l}\text { Firm size premium vs. micro enterprises } \\
\qquad \begin{array}{l}\text { Small }=28.6-47.1 \% \\
\text { Medium }=83.2-109.6 \% \\
\text { Large }=103.9-133.2 \%\end{array}\end{array}$ \\
\hline $\begin{array}{l}\text { Falco et al. (2011) } \\
\text { Ghana and Tanzania, urban labor }\end{array}$ & $\begin{array}{l}\text { Panel data with controls for } \\
\text { endogenous sorting. }\end{array}$ & $\begin{array}{l}\text { Elasticity of earnings }=.44-.46 \text { with respect to firm size and } .38-.50 \text { with } \\
\text { respect to number of employees. }\end{array}$ \\
\hline $\begin{array}{c}\text { Velenchik (1997) } \\
\text { Zimbabwe, manufacturing, } 1993\end{array}$ & $\begin{array}{l}\text { Matched employer-employee data. } \\
\text { Controls for compensating } \\
\text { differentials and human capital } \\
\text { characteristics, including on- and } \\
\text { off-the-job training. }\end{array}$ & $\begin{array}{l}\text { Firm size premium vs. small enterprises (1-10 employees) } \\
\qquad \begin{array}{l}\text { Medium }=46.5 \% \\
\text { Large }=76 \% \\
\text { Very Large }=91.7 \%\end{array}\end{array}$ \\
\hline $\begin{array}{l}\text { Teal (2017) } \\
\text { Ghana, firm-level panel } \\
\text { data for } 1962-2014\end{array}$ & $\begin{array}{l}\text { Controls for human capital } \\
\text { characteristics and time-invariant } \\
\text { unobservable effects. }\end{array}$ & Firm size premium $=34-81 \%$ \\
\hline $\begin{array}{l}\text { Gollin et al. (2014) } \\
72 \text { LDCs }\end{array}$ & $\begin{array}{l}\text { Controls for labor in agriculture } \\
\text { doing non-agricultural work (and } \\
\text { vice versa) and for differences in } \\
\text { hours worked, human capital, cost } \\
\text { of living, and public amenities. }\end{array}$ & $\begin{array}{l}\text { Ratio of labor productivity in non-agriculture vs. agriculture: } \\
\text { Poorest quartile of LDCs }=3.0 \\
\text { Third quartile of LDCs }=1.9 \\
\text { Average }=2.6, \text { National Accounts data } \\
\text { Average }=2.2, \text { microeconomic data }{ }^{1}\end{array}$ \\
\hline
\end{tabular}




\begin{tabular}{|c|c|c|}
\hline Study, Country & Data, Estimation Technique & Wage Premia \\
\hline $\begin{array}{c}\text { Bargain and Kwenda (2014) } \\
\text { Brazil, Mexico, and South } \\
\text { Africa, urban males aged 15-65 }\end{array}$ & $\begin{array}{l}\text { Panel data. Fixed effects } \\
\text { estimates and propensity score } \\
\text { matching. }\end{array}$ & 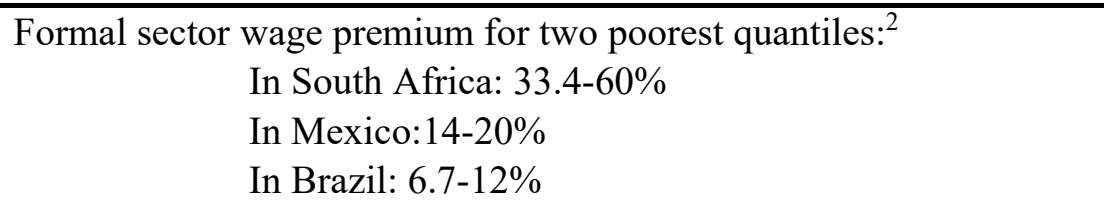 \\
\hline $\begin{array}{l}\text { Tansel et al. (2015) } \\
\text { Egypt, 1998-2012 }\end{array}$ & Panel data. & $\begin{array}{l}\text { Formal sector premium }=20.7 \%(70.2 \% \text { counting social security } \\
\text { contributions of employers }) . \\
\text { Premium for educated male workers }=27.8 \%(80.2 \% \text { counting social } \\
\text { security contributions of employers }) \text {. }\end{array}$ \\
\hline $\begin{array}{c}\text { Maloney and Ribeiro (1999) } \\
\text { Mexico, } 1992\end{array}$ & $\begin{array}{l}\text { 2SLS with controls for firm } \\
\text { characteristics and human capital } \\
\text { (including training). }\end{array}$ & $\begin{array}{l}\text { At the } 50^{\text {th }} \text { percentile, the firm size premium equals } 39.1 \% \text { for skilled } \\
\text { workers and } 75.1 \% \text { for unskilled workers. }\end{array}$ \\
\hline $\begin{array}{l}\text { Beagle et al. (2011) } \\
\text { Tanzania, 1992-2004 }\end{array}$ & $\begin{array}{l}\text { Data tracks migrants' income and } \\
\text { consumption. 2SLS with controls } \\
\text { for many sources of unobserved } \\
\text { heterogeneity. }\end{array}$ & Earnings premium for non-agriculture vs. agriculture $=41 \%$. \\
\hline $\begin{array}{c}\text { Manda (2002) } \\
\text { Kenya, 1993-1995 }\end{array}$ & $\begin{array}{l}\text { Data for the manufacturing } \\
\text { sector. Numerous controls for } \\
\text { work conditions and observable } \\
\text { firm and worker characteristics. } \\
\text { No controls for unobservable } \\
\text { heterogeneity. }\end{array}$ & $\begin{array}{l}\text { Firm-size premium vs. micro enterprises } \\
\qquad \begin{array}{l}\text { Small }=18-19 \% \\
\text { Medium }=47-49 \% \\
\text { Large }=59-68 \% \\
\text { Very Large }=88-172 \%\end{array}\end{array}$ \\
\hline
\end{tabular}




\begin{tabular}{|c|c|c|}
\hline Study, Country & Data, Estimation Technique & Wage Premia \\
\hline $\begin{array}{l}\text { Glinskaya and Lokshin (2005) } \\
\text { India, 1990-2000 }\end{array}$ & $\begin{array}{l}\text { Data from a representative } \\
\text { national survey, but sample } \\
\text { restricted to wage employees. } \\
\text { Three different estimation } \\
\text { methods: (i) OLS with controls } \\
\text { for observable human capital } \\
\text { characteristics; (ii) Correction for } \\
\text { sector selection bias; and (iii) } \\
\text { Propensity Score Matching. }\end{array}$ & $\begin{array}{l}\text { Private formal sector wage premium vis-à-vis informal wage employment } \\
=102-157 \% . \text { (Informal sector }=\text { firms with less than ten employees.) }\end{array}$ \\
\hline $\begin{array}{l}\text { Marcelle and Strobl, } 2003 \\
\text { Trinidad and Tobago, 1996-1998 }\end{array}$ & $\begin{array}{l}\text { National household survey. } \\
\text { Sample is for full-time workers } \\
\text { aged } 15-70 \text { in the private sector. } \\
\text { Controls for human capital } \\
\text { characteristics. }\end{array}$ & $\begin{array}{l}\text { Two categories: firms with } 1-9 \text { employees vs. firms with } 10+\text { employees. } \\
\text { Firm-size effect raises the wage for unskilled workers } 30 \% \text { and the wage } \\
\text { for skilled workers } 61 \% \text {. }\end{array}$ \\
\hline $\begin{array}{l}\text { Botelho and Ponczek (2011) } \\
\text { Brazil, 1995-2001 }\end{array}$ & $\begin{array}{l}\text { Panel data for six major } \\
\text { metropolitan areas covering } 30 \% \\
\text { of the population. Fixed-effect } \\
\text { estimates. }\end{array}$ & $\begin{array}{l}\text { Formal sector premium }=16 \% \text { for the poorest quartile and } 8.1 \% \text { for the } \\
\text { second quartile. No premium for the third and fourth quartiles. But the } \\
\text { wage variable is net of taxes and the estimates control for firm size. }\end{array}$ \\
\hline
\end{tabular}

${ }^{1}$ For Cobb-Douglas technology, MPL $n / \mathrm{MPL}_{a}=\left(\theta_{n} / \theta_{a}\right) \mathrm{APL}_{n} / \mathrm{APL}_{a}$, where MPL is the marginal product of labor, $\theta$ is the cost share of labor, APL is the average product of labor (labor productivity), and $n$ and $a$ denote non-agriculture and agriculture.

${ }^{2}$ Underestimates because the formal sector wage is calculated net of taxes and social security contributions paid by workers. 


\section{Appendix B. Wage Curves and Unemployment.}

\begin{tabular}{|c|c|}
\hline Study, Country & Elasticity of the Real Wage with Respect to the Unemployment Rate \\
\hline $\begin{array}{c}\text { Berg and Contreras (2004) } \\
\text { Chile, Greater Santiago Area, 1974-1996 }\end{array}$ & $\begin{array}{l}\text { Aggregate }=-0.076 \\
\text { University education }=-0.08, \text { No university education }=-0.11 \\
\text { Formal sector }=-0.08 \text {, Informal sector }=-0.03 \text { (insignificant) } \\
\text { Estimate for informal sector is restricted to self-employed workers. }\end{array}$ \\
\hline $\begin{array}{l}\text { Baltagi et al. (2013) } \\
\text { Turkey, 2005-2009 } \\
\text { Excludes agricultural workers }\end{array}$ & 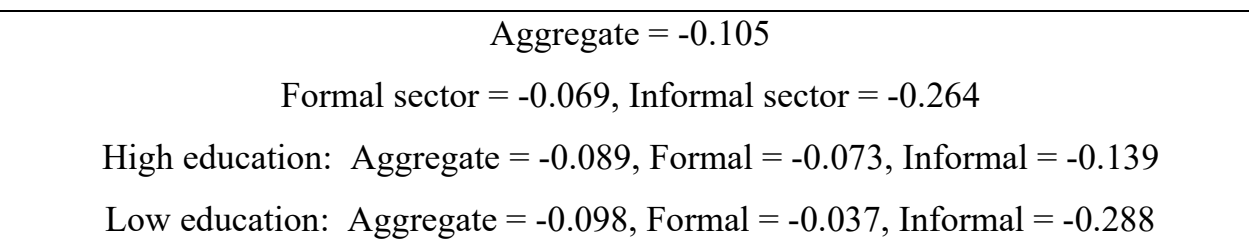 \\
\hline $\begin{array}{c}\text { Ramos et al. (2010) } \\
\text { Colombia, 2002-2006 } \\
\text { Covers } 13 \text { metropolitan areas and } 45.2 \% \text { of } \\
\text { the population }\end{array}$ & $\begin{array}{c}\text { Aggregate }=-0.071 \\
\text { Formal sector }=-0.060 \text { (insignificant), Informal sector }=-0.179\end{array}$ \\
\hline $\begin{array}{l}\text { Bucheli and Gonzalez (2007) } \\
\text { Uruguay, 1991-2005 } \\
\text { National sample, but under-coverage of } \\
\text { agriculture }\end{array}$ & $\begin{array}{c}\text { Aggregate (private sector) }=-0.132 \\
\text { Formal sector }=-0.058, \text { Informal sector }=-0.241 \\
\text { Education: } 0-8 \text { years }=-0.158 ; 9-11=-0.144 ; 12+=-0.04 \text { (insignificant) }\end{array}$ \\
\hline $\begin{array}{c}\text { Castro Lugo (2006) } \\
\text { Chile, 1992-2002 } \\
\text { Sample covers only the urban sector }\end{array}$ & $\begin{array}{c}\text { Aggregate (private sector): Male }=-0.039, \text { Female }=-0.048 \\
\text { Formal: Male }=-0.031, \text { Female }=-0.040 \quad \text { Informal: Male }=-0.040, \text { Female }=-0.057 \\
\text { High Education: Male }=0,-0.045, \text { Female }=\text { insignificant }\end{array}$ \\
\hline
\end{tabular}




\begin{tabular}{|c|c|}
\hline Study, Country & Elasticity of the Real Wage with Respect to the Unemployment Rate \\
\hline $\begin{array}{c}\text { Alcaraz (2009) } \\
\text { Mexico, 1995-2001 }\end{array}$ & Formal sector $=0$, Informal sector $=-0.138$ \\
\hline $\begin{array}{l}\text { Arango et al. (2010) } \\
\text { Colombia, different data sources } \\
\text { for 2001-2009 }\end{array}$ & $\begin{array}{l}\text { Local (city) unemployment rate: }-0.009 \text { to }-0.167 \text {; cell mean }=0 \text { to }-0.103 \\
\text { Group unemployment rate: }-0.086 \text { to }-0.108 \text {; cell mean }=-0.044 \text { to }-0.097\end{array}$ \\
\hline $\begin{array}{l}\text { Garcia and Granados (2005) } \\
\text { Chile, three different national surveys } \\
\text { for } 1990-2003\end{array}$ & $\begin{array}{l}\text { Regional unemployment rate: }-0.04 \\
\text { Sectoral unemployment rate: }-0.13 \text {. }\end{array}$ \\
\hline $\begin{array}{l}\text { Hoddinott (996) } \\
\text { Côte d'Ivoire, 1985-1987, } \\
\text { males in urban areas. }\end{array}$ & $\begin{array}{c}\text { Aggregate }=-0.119 \\
\text { Education: Primary or less }=-0.215, \text { More than primary }=-0.111 \\
\text { Professional }=0, \text { Non-professional }=-0.127\end{array}$ \\
\hline $\begin{array}{l}\text { Ilkkaracan et al. (2003) } \\
\text { Turkey, firms with } 10+\text { employees }\end{array}$ & $\begin{array}{c}\text { Aggregate private sector }=-0.135 \\
\text { Primary education or less }=-0.23 \\
\text { Primary-high school education }=-0.172 \\
\text { College graduates }=-0.029 \text { (insignificant) } \\
\text { Non-agricultural labor }=-0.15,-0.43\end{array}$ \\
\hline $\begin{array}{l}\text { Kingdon and Knight (1999) } \\
\text { South Africa, } 1993\end{array}$ & $\begin{array}{c}\text { All workers }=-0.108 \\
\text { Private sector }=-0.141 \text { at mean unemployment rate; } \\
-0.067,-0.101 \text { evaluated at unemployment rate of } 25-30 \% \\
\text { Urban }=-0.135 \text { (evaluated at mean unemployment rate) } \\
\text { Rural }=-0.122 \text { (evaluated at mean unemployment rate) }\end{array}$ \\
\hline
\end{tabular}




\begin{tabular}{|c|c|c|c|}
\hline Study, Country & \multicolumn{3}{|c|}{ Elasticity of the Real Wage with Respect to the Unemployment Rate } \\
\hline Mudiriza and Edwards (2018) & \multicolumn{3}{|c|}{ Aggregate $=-0.091$} \\
\hline South Africa, 2011 & \multicolumn{3}{|c|}{ Private sector $=-0.052$} \\
\hline von Fintel (2015) & \multirow{2}{*}{\multicolumn{3}{|c|}{ Close to zero in the short run and approximately -0.1 in the long run }} \\
\hline South Africa, 2000-2004 & & & \\
\hline Baltagi et al (2017) & \multicolumn{3}{|c|}{ Aggregate $=-0.107$} \\
\hline \multirow[t]{4}{*}{ Brazil, 2002-2009 } & \multicolumn{3}{|c|}{ Formal $=-0.039$ (insignificant), Informal $=-0.246$} \\
\hline & \multicolumn{3}{|c|}{ Age $15-29=-0.154$, Age $30-44=-0.030$ (insignificant) } \\
\hline & \multirow{2}{*}{\multicolumn{3}{|c|}{$\begin{array}{c}\text { Tenure }<1=-0.180,1<\text { Tenure }<5=-0.137, \text { Tenure }>5=\text { insignificant } \\
\text { Low skill }=-0.048 \text { (insignificant), Medium skill }=-0.110\end{array}$}} \\
\hline & & & \\
\hline Castro Lugo (2006) & \multicolumn{3}{|c|}{ Aggregate $=-0.037,-0.039$} \\
\hline \multirow[t]{8}{*}{ Mexico, urban workers, 1993-2002 } & & Male & Female \\
\hline & Private sector & -0.039 & -0.048 \\
\hline & Formal sector & -0.031 & -0.040 \\
\hline & Informal sector & -0.058 & -0.057 \\
\hline & High education & -0.045 & insignificant \\
\hline & Low education & $-0.044,-0.065$ & $-0.041,-0.057$ \\
\hline & Age $<26$ & $-0.063,-0.068$ & $-0.063,-0.070$ \\
\hline & Age $26-45$ & $-0.017,-0.067$ & $-0.023,-0.031$ \\
\hline
\end{tabular}




\begin{tabular}{|c|c|}
\hline Study, Country & Elasticity of the Real Wage with Respect to the Unemployment Rate \\
\hline Lopez Machuca and Mendoza Cota (2017) & Aggregate $=-0.023,-0.045$ \\
\hline Mexico, manufacturing sector, $2007-2015$ & Period of greater stability $(07 / 2009-12 / 2015)=-0.092,-0.131$ \\
\hline Galiani (1999) & Aggregate: short run $=-0.04$, long run $=-0.082$ \\
\hline Argentina, urban areas, 1990-1997 & Males: short run $=-0.057$, long run $=-0.119$ \\
\hline $\begin{array}{l}\text { Galindo and Catalan (2010) } \\
\text { Mexico, 1989-2008 }\end{array}$ & Aggregate $=-0.032$ \\
\hline $\begin{array}{l}\text { Baltagi et al. (2012) } \\
\text { Turkey, 2005-2008 }\end{array}$ & $\begin{array}{c}\text { Aggregate }=-0.099 \\
\text { Young }(<34)=-0.108(-0.243), \text { Old }=-0.081(-0.177) \\
\text { Male }=-0.069, \text { Female }=-0.237 \\
\text { Urban }=-0.101, \text { Rural }=-0.105 \text { (insignificant }) \\
\text { Tenure: Low }(<6.9 \text { years })=-0.175(-0.309), \text { High }=-0.011 \text { (insignificant) } \\
\text { Education: Low }(<8 \text { years })=-0.086(-0.632), \text { High }=-0.067 \text { (-0.088, insignificant }) \\
\text { Note: Figures in parentheses are for women. }\end{array}$ \\
\hline $\begin{array}{c}\mathrm{Wu}(2004) \\
\text { China, urban youth, 1989-1999 }\end{array}$ & Aggregate $=-0.224$ \\
\hline $\begin{array}{l}\text { Park and Shin (2008) } \\
\text { Korea, 1998-2002 }\end{array}$ & Aggregate $=-0.075,-0.098$ \\
\hline $\begin{array}{c}\text { Appleton et al. (2005) } \\
\text { China, urban areas, 1998-2002 }\end{array}$ & Semi-elasticity $=-0.667$. Elasticity evaluated at the mean unemployment rate $=-0.046$. \\
\hline $\begin{array}{l}\text { Pradhan and van Soest (1995) } \\
\text { Bolivia, 1989, eight urban areas }\end{array}$ & $\begin{array}{l}\text { Formal sector: Male }=-0.083,-0.085, \text { Female }=-0.088,-0.091 \\
\text { Informal Sector: Male }=-0.11,-0.15, \text { Female }=-0.11\end{array}$ \\
\hline
\end{tabular}

